\title{
STRUCTURAL AND METAMORPHIC EVOLUTION OF THE TURKU MIGMATITE COMPLEX, SOUTHWESTERN FINLAND
}

\author{
MARKKU VÄISÄNEN and PENTTI HÖLTTÄ
}

VÄISÄNEN, MARKKU and HÖLTTÄ, PENTTI 1999. Structural and metamorphic evolution of the Turku migmatite complex, southwestern Finland. Bulletin of the Geological Society of Finland 71, Part 1, 177-218.

The Turku migmatite complex in southwestern Finland is a representative area for the type of tectonic and metamorphic evolution seen within the Palaeoproterozoic Svecofennian Orogen in southern Finland. The orogeny can be divided into early, late and postorogenic stages. The early orogenic structural evolution of the crust is expressed by a $D_{1} / D_{2}$ deformation recorded as bedding-parallel $S_{1}$ mica foliation deformed by tight to isoclinal $D_{2}$ folds with subhorizontal axial planes and a penetrative $S_{2}$ axial plane foliation. Syntectonic ca. 1890-1870 Ma tonalites were emplaced during $\mathrm{D}_{2}$ as sheet intrusions. This deformation is attributed to thrust tectonics and thickening of the crust. The late orogenic structural evolution produced the main $\mathrm{D}_{3}$ folding, which transposed previous structures into a NE-SW trend. The doubly plunging fold axis produced dome-andbasin structures. The attitude of the $\mathrm{F}_{3}$ folds varies from upright or slightly overturned to locally recumbent towards the NW. Granite dikes were intruded along $\mathrm{S}_{3}$ axial planes. Large $\mathrm{D}_{3}$ fold limbs are often strongly deformed, intensively migmatized and intruded by garnet- and cordierite-bearing granites. These observations suggest that these potassium-rich granites, dated at 1840-1830 Ma, were emplaced during $\mathrm{D}_{3}$. This late orogenic NW-SE crustal shortening further contributed to crustal thickening. Subvertical $\mathrm{D}_{4}$ shear zones that cut all previous rock types possibly controlled the emplacement of postorogenic granitoids. Steeply plunging lineations on $\mathrm{D}_{4}$ shear planes suggest vertical displacements during a regional uplift stage.

Metamorphic grade increases from cordierite-sillimanite-K-feldspar gneisses in the northwest and from muscovite-quartz \pm andalusite rocks in the southeast to high-temperature granulite facies migmatites in the middle of the study area. Block movements during $\mathrm{D}_{4}$ caused the observed differences in metamorphic grade. Garnet and cordierite are mostly breakdown products of biotite and sillimanite and their growth is mainly syntectonic with $\mathrm{D}_{2}$; they are elongated within the $S_{2}$ plane and deformed by $D_{3}$ folds. Leucosome veins were already produced during $\mathrm{D}_{2}$, but in situ melting began during $\mathrm{D}_{3}$ producing granitic leucosomes with euhedral garnet and cordierite along the axial planes of $\mathrm{F}_{3}$. Garnet is typically altered to cordierite and plagioclase in the presence of sillimanite, indicating decompression close to the temperature maximum. Pressure and temperature estimates from garnet and cordierite indicate that the granulites reached temperatures in excess of $800^{\circ} \mathrm{C}$ at approximately $6 \mathrm{kbar}$ pressure while the adjacent amphibolite facies rocks crystallized at $100-150^{\circ} \mathrm{C}$ and $1-2 \mathrm{kbar}$ lower temperatures and pressures. Therefore, the granulite areas represent the deepest structural levels in the area. Structural and metamorphic observations 
indicate that peak metamorphism was reached during the compressional late orogenic $\mathrm{D}_{3}$ stage ca. 1840-1830 Ma ago. Crustal thickening simultaneous with thinning of the mantle lithosphere may explain this kind of tectono-metamorphic evolution.

Key words: structural geology, crustal thickening, granulite, low pressure metamorphism, Proterozoic, Svecofennian, Turku, Finland

Markku Väisänen: Department of Geology, FIN-20014 University of Turku, Finland.

Present address: Geological Survey of Finland, P.O. Box 96, FIN-02151 Espoo, Finland.

E-mail: markku.vaisanen@gsf.fi

Pentti Hölttä: Geological Survey of Finland, P.O. Box 96, FIN-02151 Espoo, Finland.

E-mail:pentti.holtta@gsf.fi

\section{INTRODUCTION}

After the pioneering work of Hietanen (1975), the evolution of the Svecofennian Orogen has been increasingly interpreted within the framework of the modern plate tectonic paradigm. The orogeny was initiated by rifting of the Archaean craton and the formation of an ocean floor, now preserved as the 1.95 Ga Jormua Ophiolite (Kontinen 1987, Kohonen 1995, Peltonen et al. 1996) and the subsequent generation of an island arc system which collided with and thrusted over the Archaean basement at $1.9 \mathrm{Ga}$ (Koistinen 1981, Gaál \& Gorbatschev 1987, Lahtinen 1994, Peltonen et al. 1996). At the same time further south several island arcs, composed of juvenile mantle material (Huhma 1986) developed contemporaneously and collided with each other at 1.89-1.88 Ga (Lahtinen 1994). Windley (1995) has therefore classified the Svecofennian Orogen as an arc-accretionary orogen. Although the island arc origin is reasonably well understood, the tectonic setting of the sedimentary basins between island arcs is not adequately known. Quite recently there has also been progress in this aspect and Lahtinen (1994) and Kähkönen (1996) interpreted the Vammala tonalite migmatites as an accretionary complex related to the Tampere volcanic arc in the north (Fig. 1).

Accretion of island arcs together with mafic underplating resulted in thickening of the crust that is now up to $65 \mathrm{~km}$ thick in central Finland and
$42 \mathrm{~km}$ in southern Finland (Korja et al. 1993, Lahtinen 1994). Although the Svecofennian orogeny created one of the thickest crusts in the Precambrian there are no high-pressure rocks exposed at the surface and the present erosion level exposes only upper and middle crust.

Southern Finland is characterized by high-T/ low-P migmatites and granites which form the late Svecofennian granite-migmatite (LSGM) zone as defined by Ehlers et al. (1993a). Three main models have been proposed for its tectonic setting. Ehlers et al. (1993a) introduced the idea of dextral transpression in which NW directed compression was associated with westward flow of granite sheets. This model is based on dextral deflection of an earlier foliation towards the shear direction and westward imbrication of elongated $\mathrm{K}$ feldspar megacrysts in the granites, interpreted as stretching lineations by Ehlers et al. (1993a). Van Duin and Nieman (1993) concluded that high-temperature metamorphism was achieved by contemporaneous thickening of the crust associated with the thinning of the mantle lithosphere and intrusion of mafic magma into the base of the crust. Subsequent melting of the lower crust provided heat for metamorphism in the form of upwards migrating magmas. Korja et al. (1993) showed that the crust in southern Finland is locally more than $20 \mathrm{~km}$ thinner than in areas further north. Thinned crust in southern Finland and gently dipping reflectors seen on seismic reflection profiles (BA- 


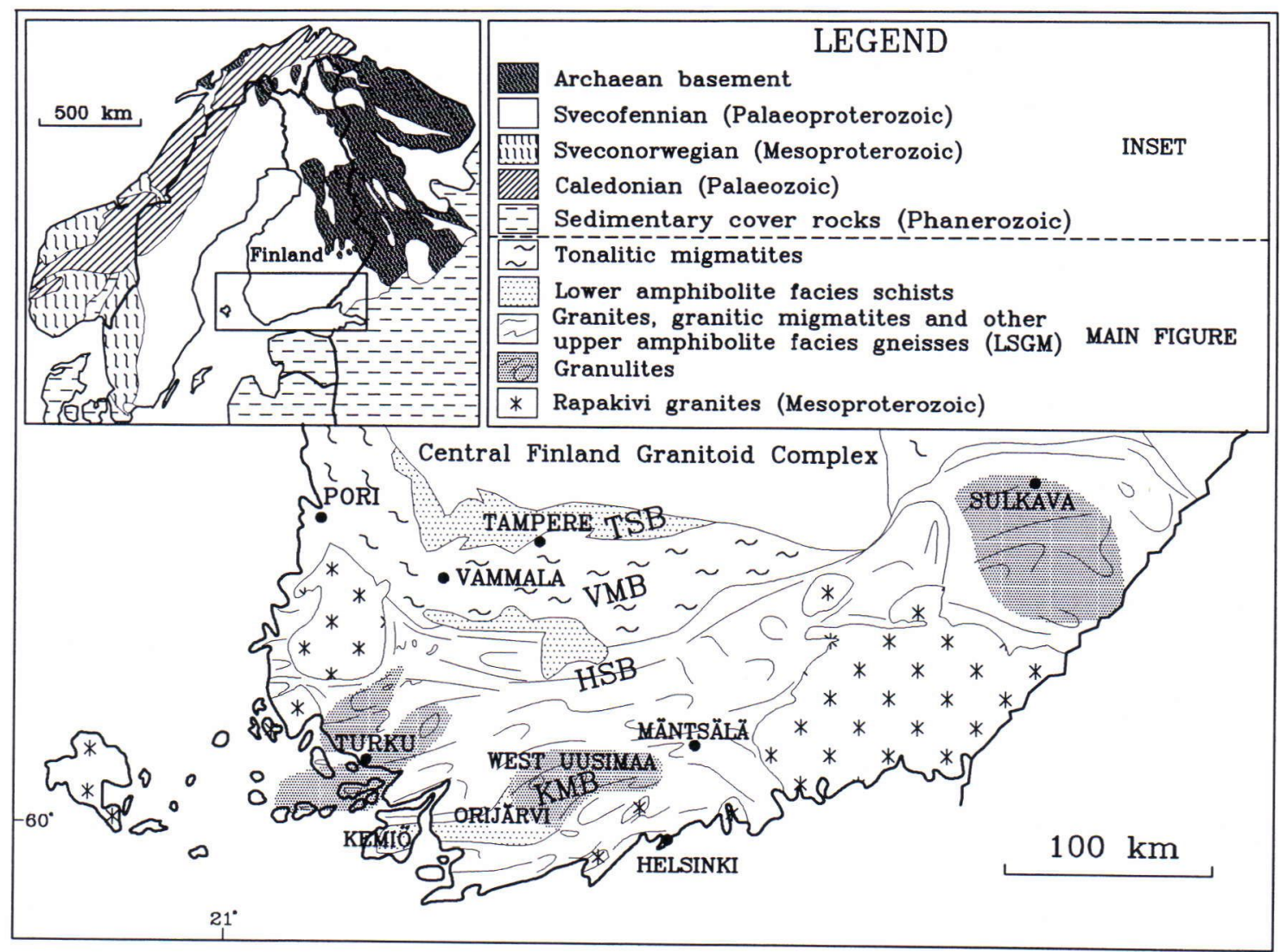

Fig. 1. General geological map of southern Finland. Modified after Koistinen (1994). HSB = Häme Schist Belt, $K M B=$ Kemiö-Mäntsälä Belt, LSGM (in the legend) = late Svecofennian granite-migmatite zone, TSB = Tampere Schist Belt, VMB = Vammala Migmatite Belt. Granulite areas are according to Korsman et al. (1997).

BEL Working Group 1993), interpreted as listric shear zones, led Korja and Heikkinen (1995) to propose a model of extensional collapse of an overthickened orogen. They suggested that extension began 1.84-1.81 Ga ago, simultaneously with the intrusion of the late orogenic granites. This idea was recently supported by Nironen (1997). According to Lahtinen (1994), however, petrological evidence implies that extension initiated slightly later in connection with the within-plate type alkaline magmatism, i.e. the postorogenic 1.815-1.770 Ga magmatism.

A study of the structural history and deformation style and the relative timing of metamorphic mineral growth in relation to deformation phases can reveal whether compressional or extensional tectonics dominated during the high-T event. Timing of deformation in relation to melting and emplacement of intrusive rocks gives time constraints on deformation events and metamorphism. The purpose of this study is to describe the mutual relationships of metamorphism, deformation and magmatism in the Turku migmatite complex, which forms a representative section of the late Svecofennian granite-migmatite zone.

\section{GEOLOGICAL SETTING}

The Turku area is situated in the western part of the late Svecofennian granite-migmatite (LSGM) zone of southern Finland (Fig. 1). The ENE-WSW 


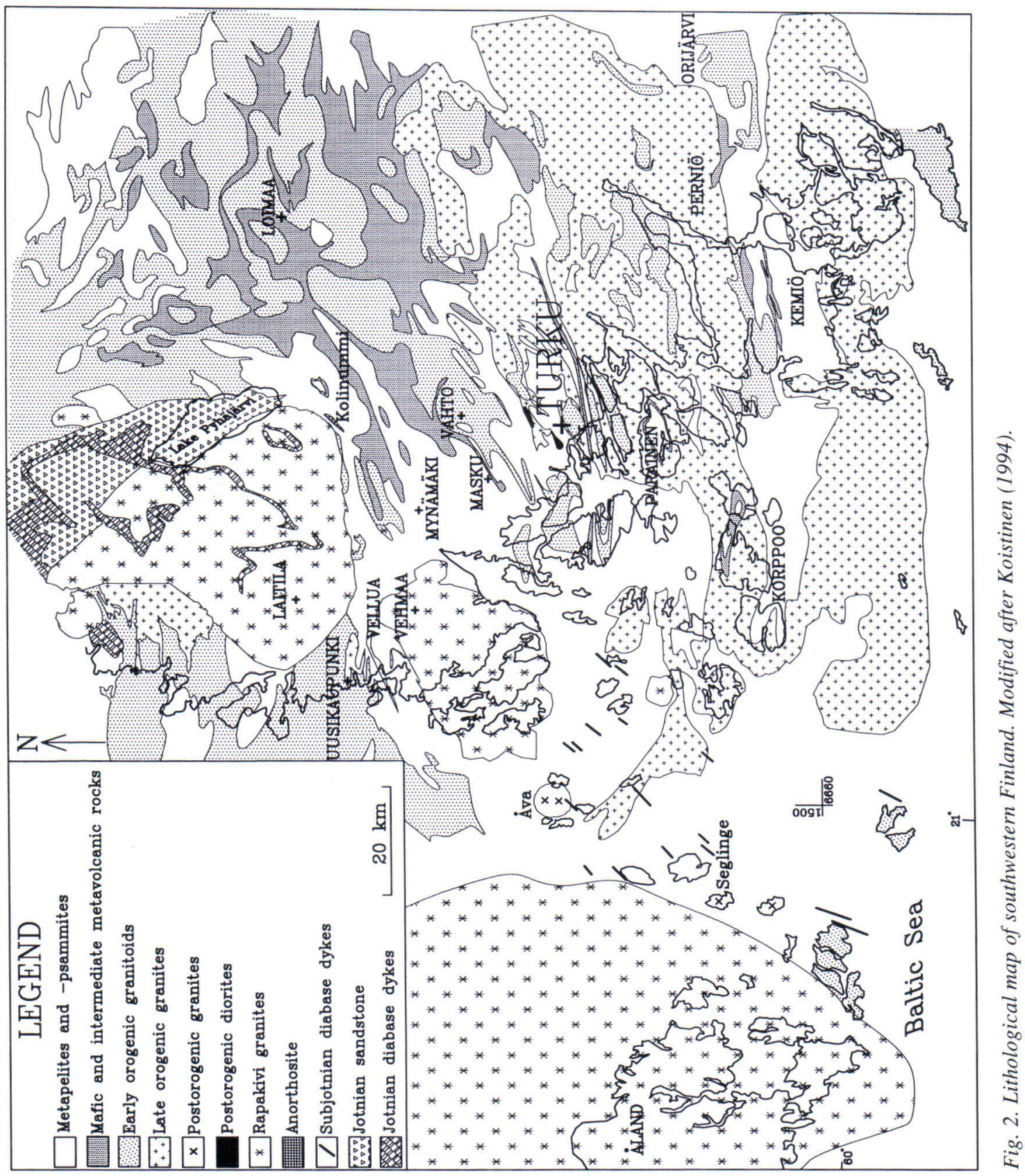

trending zone is about $500 \mathrm{~km}$ long and $100 \mathrm{~km}$ wide, and is characterized by large volumes of late orogenic S-type granites and associated migmatites, dated at ca. 1.84-1.83 Ga (Huhma 1986, Suominen 1991, Ehlers et al. 1993a). Granites and migmatites in the LSGM zone are roughly contemporaneous with high-T/low-P metamorphism which locally reached granulite facies conditions at about $700-800^{\circ} \mathrm{C}$ and $4-6$ kbar in Sulkava, western Uusimaa and Turku (Fig. 1, Korsman et 


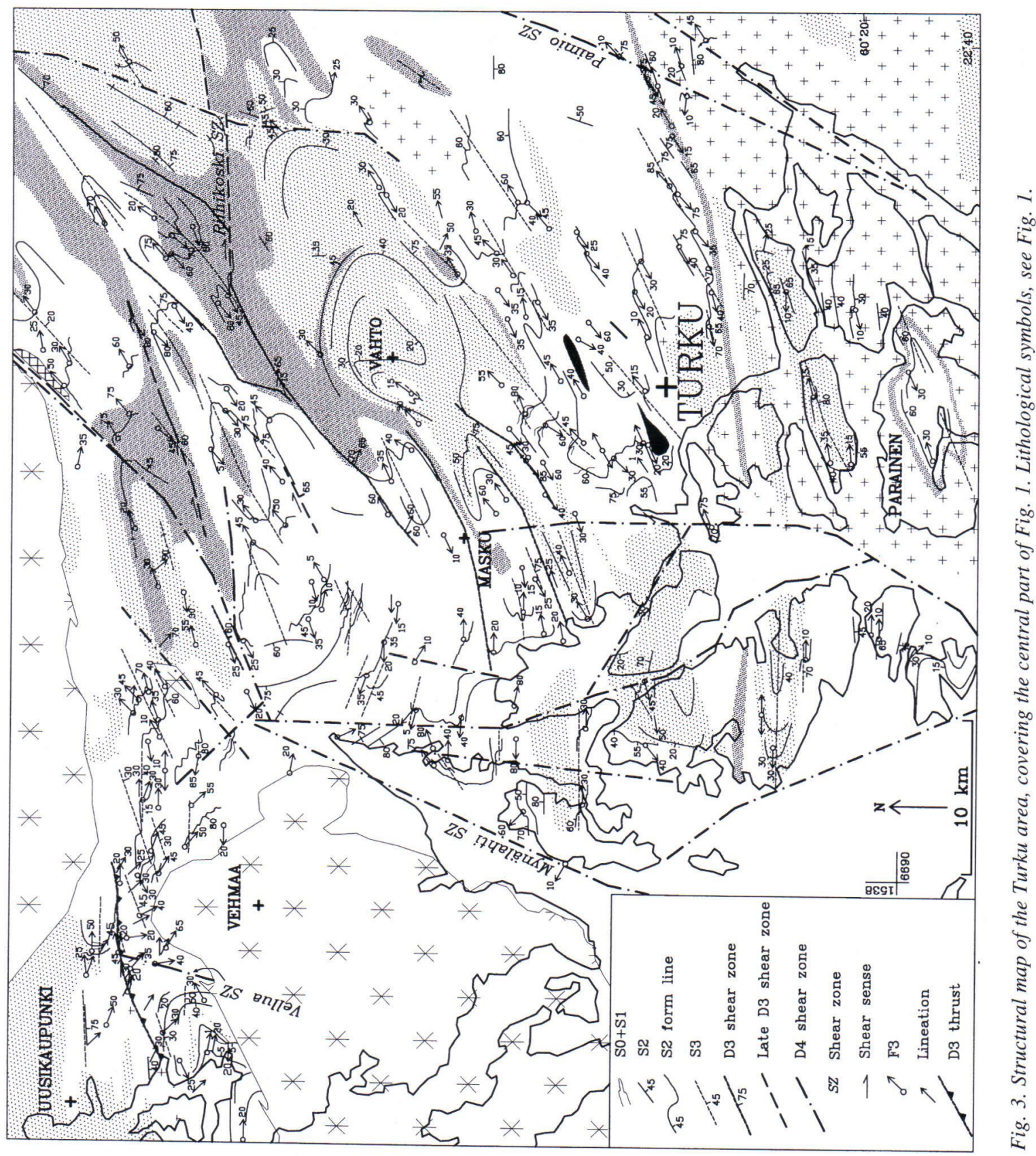

al. 1984, Hölttä 1986, Schreurs \& Westra 1986, van Duin \& Nieman 1993). Deformation and metamorphism in this zone overprint the $1.88 \mathrm{Ga}$ Svecofennian evolution that dominates other parts of the southern Svecofennian Orogen in Finland.
For example, in the Tampere-Vammala area ca. $150 \mathrm{~km}$ north of Turku, arc magmatism, deformation and metamorphism took place $1.90-1.88 \mathrm{Ga}$ ago and the associated high-temperature metamorphism produced tonalitic rather than granitic 
migmatites seen in southernmost Finland (Kähkönen et al. 1989, Nironen 1989a, Kilpeläinen et al. 1994, Korja et al. 1994, Kilpeläinen 1998).

The Turku area can be subdivided into two major geological domains on the basis of their distinctive metamorphic and lithological features. These are the Kemiö-Orijärvi domain and the Turku domain. The Kemiö-Orijärvi domain, which is part of the Kemiö-Mäntsälä Belt (Figs. 1 and 2), is characterized by island arc type bimodal tholeiitic and calc-alkaline metavolcanic rocks, metasedimentary rocks, and $\mathrm{Cu}-\mathrm{Zn}-\mathrm{Pb}$ mineralizations associated with hydrothermally altered rocks. It was metamorphosed at lower amphibolite facies (mainly muscovite grade, close to the andalusite-sillimanite boundary) and some of the altered volcanic rocks were metamorphosed to cordierite-orthoamphibole rocks (Eskola 1914, Latvalahti 1979, Dietvorst 1982, van Staal \& Williams 1983, Schreurs \& Westra 1986, Colley \& Westra 1987, Ploegsma \& Westra 1990, Schneiderman \& Tracy 1991, Lindroos \& Ehlers 1994). It is bordered in the west by the NNE trending Paimio shear zone and in the north by the Perniö granite (Figs. 2 and 3). The Turku domain, to the north and west of the Kemiö-Orijärvi domain, consists mainly of upper amphibolite facies and granulite facies migmatitic metapelites, basaltic and andesitic calc-alkaline metavolcanic rocks, tonalites and anatectic potassium-rich granites. Tonalites in the highest grade areas are orthopyroxene-bearing enderbites (Hietanen 1943, 1947, Härme 1960, van Duin 1992). Metamorphic grade increases from northwest to southeast, from cordierite-K-feldspar gneisses to high-temperature granulites.

The majority of the supracrustal rocks in the Turku domain are various metasedimentary rocks with well-preserved bedding observed in places where not destroyed by strong deformation or melting. The variable thickness and composition of the alternating pelitic and psammitic beds suggests a turbiditic origin of the metasediments. North of the Vehmaa rapakivi granite, in the cordierite- K-feldspar zone, the metasediments are rather homogeneous, lack clear turbiditic structures, and are mainly psammitic in composition.
North of Vahto the metasediments are intercalated with mafic to intermediate metavolcanic rocks (Hietanen 1947, van Duin 1992), and at Parainen, south of Turku, the metavolcanic rocks are associated with limestones metamorphosed to marbles. Metavolcanic rocks become more common towards the Loimaa area (Fig. 2) where they probably represent part of the island arc type Häme Schist Belt (HSB) described by Hakkarainen (1994). Age data on the volcanism and sedimentation are scarce, but the uppermost formation of metavolcanic rocks in the HSB, $100 \mathrm{~km} \mathrm{NE}$ of Turku, yielded a U-Pb zircon age of $1888 \pm 11 \mathrm{Ma}$ (Vaasjoki 1994). This minimum age of volcanism may also be valid for the Turku area, because the HSB and Turku areas are on the same side of a suture zone proposed by Lahtinen (1994), that runs along the southern border of the Vammala Migmatite Belt (VMB) (Fig. 1).

In southern Finland the intrusive rocks have traditionally been classified into early orogenic (also called synorogenic or synkinematic), late orogenic (serorogenic or late kinematic), postorogenic and anorogenic intrusions, analogous to the original classification of intrusive rocks into four groups by Sederholm (1934). All these groups are present in the Turku area. The classification is perhaps imprecise in a tectonic sense (see Nironen 1997), but is still valid when the relative ages of magmatic events in this part of the Svecofennides are considered and therefore the traditional terminology is used here.

The supracrustal rocks are intruded by all four stages of intrusive rocks. The early orogenic intrusive rocks comprise I-type subduction related rocks (Lahtinen 1994) ranging in composition from gabbros to trondhjemites with ages of ca. 1890-1870 Ma. This time period defines the major crustal growth episode in the Svecofennian orogeny and the main collisional stage in southern Finland (Huhma 1986, Patchett \& Kouvo 1986, Lahtinen 1994). Pyroxene-bearing tonalites, i.e. enderbites, give U-Pb zircon ages between 1820-1860 Ma (Suominen 1991, van Duin 1992). Late orogenic, coarse-grained, pink or white granites of 1840-1830 Ma ages, commonly garnet and/ or cordierite bearing, are S-type anatectic crustal 
melts related to high-T/low-P metamorphism. Modal compositions show that they are monzogranites and syenogranites and alkaline in their geochemical affinities (Hölttä 1986, Nurmi \& Haapala 1986). No mafic rocks of this age group have been found. Postorogenic (1815-1770 Ma, Vaasjoki 1996) rocks make up a volumetrically minor bimodal group of intrusive rocks spatially restricted to the LSGM zone. The mafic members of the intrusive rocks are alkaline (Hubbard \& Branigan 1987) and on geochemical discrimination diagrams they fall in within-plate type fields (Lahtinen 1994). Anorogenic rapakivi granites and coeval Subjotnian diabase dykes and anorthosites (1630-1540 Ma) form a bimodal set of magmas originating from the lower crust in an extensional tectonic setting (Haapala \& Rämö 1992). The latest Precambrian events in SW Finland were rifting of the Svecofennian crust and the formation of the Satakunta graben filled with Jotnian sandstones. The sandstones were intruded ca. $1270 \mathrm{Ma}$ ago (Suominen 1991) by Jotnian diabase dykes (Fig. 2). These youngest formations are more widespread under the Baltic Sea (Koistinen 1994).

\section{STRUCTURAL EVOLUTION OF THE TURKU DOMAIN}

The structural interpretation presented below is based on field observations using overprinting relationships of bedding, folds, cleavages, faults and magmatic intrusions following the methods discussed, e.g. by Hobbs et al. (1976). It is assumed here that the whole study area has experienced the same orogenic cycle, because there are no indications of exotic or suspect terranes. It is also assumed that if diachronism in the tectonic and magmatic events took place, the effects are negligible in such a small area and that, e.g., the timing of deformation and magmatic intrusions holds throughout the study area.

The migmatite area in SW Finland exhibits a polyphase deformation history. In most areas, a strong late orogenic deformation associated with high metamorphic grade has effectively obliterated the earliest deformation features which are only locally preserved in low strain areas. In general, early subhorizontal structures are complexly overprinted by later upright folding and faulting.

\section{Primary structures}

The earliest observable structure is the lithological layering, $\mathrm{S}_{0}$, which is well preserved in relatively weakly deformed domains, especially in the hinge zones of openly folded turbiditic metasediments. In the hinge zones, layering and foliation are perpendicular to each other, and the former, therefore, is regarded as the primary depositional bedding. Sedimentary or volcanic structures indicating depositional younging direction have not been observed, probably because complete recrystallization of clastic grains has obliterated the details of primary structures, e.g. graded bedding.

\section{$D_{1}$ deformation}

The oldest tectono-metamorphic structure is the bedding-parallel $S_{1}$ biotite foliation. The strong transposition and intensity of the later deformations have mostly obliterated it, and it is only found in the hinge zones of some $\mathrm{F}_{2}$ folds and as inclusion trails in $\mathrm{K}$-feldspar, garnet and cordierite porphyroblasts in lower grade rocks (see below). In some beds, where later folding and foliation are weak, $S_{1}$ can be the dominant foliation. The tectonic origin for $D_{1}$ is speculative, because no folding has been found associated with it.

\section{$D_{2}$ deformation}

Bedding and $\mathrm{S}_{1}$ foliation are deformed by isoclinal to tight $\mathrm{F}_{2}$ folds (Fig. 4a) that originally had subhorizontal axial planes. $\mathrm{D}_{2}$ still has its original subhorizontal attitude in hinge zones of the open, gently plunging, upright $\mathrm{F}_{3}$ folds (described below) where $\mathrm{F}_{2}$ folds are reclined or recumbent and $S_{2}$ is subhorizontal (Fig. 4b). The $S_{2}$ foliation is a millimetre-scale, spaced cleavage, axial planar to the $F_{2}$ folds. The intensity of $S_{2}$ varies from crenulated $S_{1}$ foliation (rare) to penetrative $S_{2}$ biotite foliation outlined by metamorphic segregations. Except in fold hinges, $S_{2}$ is parallel to bed- 

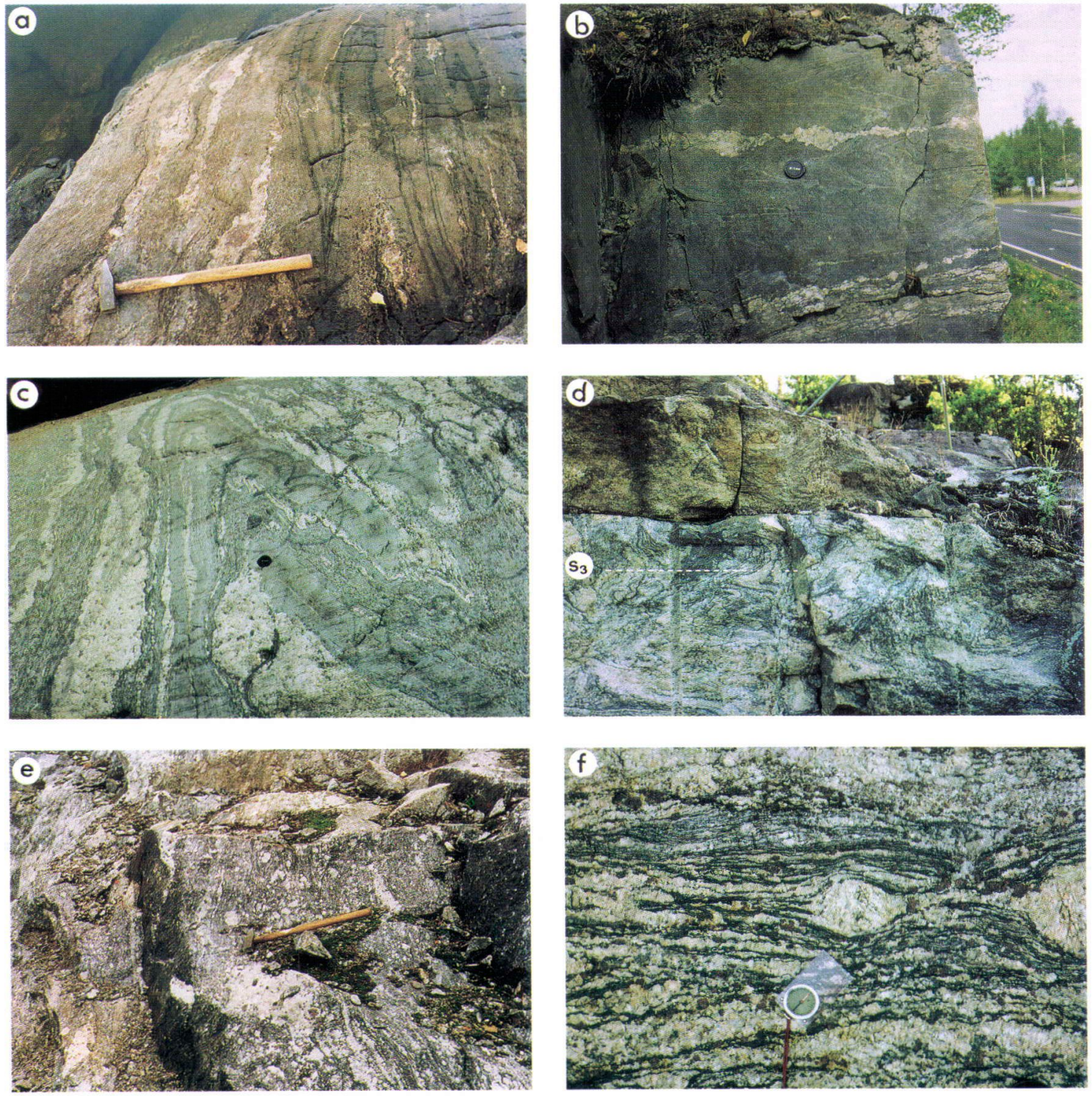

Fig. 4. Outcrop photographs of different structural styles in the pelitic $(a, c-f)$ and psammitic (b) migmatites of the Turku area. Hammer $(60 \mathrm{~cm})$, lens cap $(7 \mathrm{~cm})$ and compass $(10 \mathrm{~cm})$ for scale. a) Bedding $\left(S_{0}\right)$ and beddingparallel layering $\left(S_{1}\right)$ folded by isoclinal $F_{2}$ that is openly refolded by $F_{3}$. Patchy garnet-bearing leucosomes cut $F_{2}$ folds. Raisio, map sheet 1044 07, $x=6710750, y=1566850$. b) Recumbent $F_{2}$ folds in a road cut. Lokalahti, map sheet 1042 09, $x=6733000, y=1526950$. c) Slightly NW overturned asymmetric $F_{3}$ folding with steep NW limb and gently dipping SE limb. Masku, map sheet 1044 07, $x=6715350, y=1562650$. d) Recumbent $F_{3}$ folding in a road cut. Field of view $3 \mathrm{~m}$ wide. Parainen, map sheet 1043 11, $x=6693000, y=1575300$. e) Pseudoophthalmitic structure with $K$-feldspar megacrysts and garnetiferous melt segregations on an $F_{3}$ fold limb, road cut. Masku, map sheet 1044 04, $x=6718100, y=1560000 . f$ ) A detail of a schlieric garnetiferous protomylonite on an $F_{3}$ limb. Lemu, map sheet 1044 04, $x=6711600, y=1555500$. 
ding and therefore could be described as a composite $\mathrm{S}_{0}+\mathrm{S}_{1}+\mathrm{S}_{2}$. It is the dominant foliation (cleavage) in the study area. Only mesoscopic $\mathrm{F}_{2}$ folds have been found, usually sandwiched between apparently unfolded but strongly foliated gneisses. Large-scale $\mathrm{F}_{2}$ folds may exist but the absence of bedding/cleavage/depositional younging direction relationships makes them difficult to recognise. The plunge of the fold axis could be measured only in a few cases, because most of the observations were made on two-dimensional icepolished outcrops. Similarly, a northern vergence has been observed only in a few cases. The mineral lineation, where measured, is parallel to the fold axis.

\section{$D_{3}$ deformation}

The $\mathrm{D}_{3}$ deformation is characterized by a regional $F_{3}$ folding which deformed and locally transposed the subhorizontal $\mathrm{D}_{1}$ and $\mathrm{D}_{2}$ structures into E-W (southwestern part of the study area), NESW (central part) or NNE-SSW (NE part) trending (Fig. 3), generally upright or asymmetric inclined structures (Fig. 4c). $D_{3}$ is responsible for the main structural grain of the region. Although the fold axes are usually subhorizontal or moderately plunging, steep axes do exist, especially on the limbs of the regional folds. The $\mathrm{F}_{3}$ folding is, therefore, strongly non-cylindrical and doubly plunging folds produce dome-and-basin structures (Fig. 3). Intensity of the $\mathrm{F}_{3}$ folding varies from very open to isoclinal, sometimes with sheared fold limbs, indicating that deformation was partitioned into sheared and folded domains (cf. Bell 1985). In most cases, $F_{3}$ appears as a kilometrescale open folding (Fig. 3) that refolded pre-existing foliations. A new axial planar cleavage, $\mathrm{S}_{3}$, only developed in tight $\mathrm{F}_{3}$ folds. Axial planes of folds in the central part of the study area are vertical. In inclined folds (slightly overturned towards the NW, see Fig. 4c), they are steeply dipping to the SE. Particularly in the northern part of the study area, near rapakivi granite intrusions, the folds are clearly overturned, reclined, and recumbent folds exist locally. Recumbent folds have also been observed locally in the southern part of the study area, e.g. at Parainen (Fig. 4d). Fold axes in reclined folds are, in most cases, $\mathrm{E}$ to $\mathrm{SE}$ plunging. There is a mineral lineation parallel to the fold axes, but, in general, it was difficult to differentiate between $\mathrm{L}_{2}$ and $\mathrm{L}_{3}$, or to distinguish $\mathrm{L}_{3}$ from $\mathrm{L}_{2}$ rotated into a new direction. In general, lineations are poorly developed or are obliterated by annealing in the highest grade rocks. Therefore, no distinction between different lineation generations has been made on the structural map (Fig. 3).

\section{$D_{3}$ shear zones}

Some macroscopic $\mathrm{F}_{3}$ fold limbs are more deformed than the interior parts of the folds (Fig. 3). These shear zones are characterized by intense migmatization featuring schlieric and nebulitic structures and the appearance of K-feldspar megacrysts (Fig. 4e). Garnet- and cordierite-bearing potassium-rich granite dykes, several tens of metres wide, occur in these zones. Fold limbs show signs of progressive deformation, and earlier granitic leucosome veins and mafic dykes are deformed to augens or boudins while later granite dykes are apparently undeformed. The lack of asymmetric structures may indicate that deformation was mainly pure shear. Mesoscopically rocks in sheared $\mathrm{F}_{3}$ limbs in some cases resemble protomylonites (Fig. 4f). The shear zones are mostly subparallel to the general $\mathrm{D}_{3}$ trend and are subvertical or SE dipping. Their width varies from several tens to several hundreds of metres and folded domains pass gradually into sheared domains. Subhorizontal or SE plunging mineral lineations have locally been observed, but they could not be unambiguously interpreted as stretching lineations. It is possible that these zones are highly attenuated fold limbs that did not undergo any great displacements. Outside the granitisized shear zones within the folded domains, similar shear zones, but smaller in scale ( $\mathrm{cm}$ to $\mathrm{m}$ scale), also occur. In some cases they form conjugate sets filled with granite. Folds are, occasionally, turned into the shear zones.

North of the Vehmaa rapakivi intrusion a subarea displays recumbent early folds refolded by a 

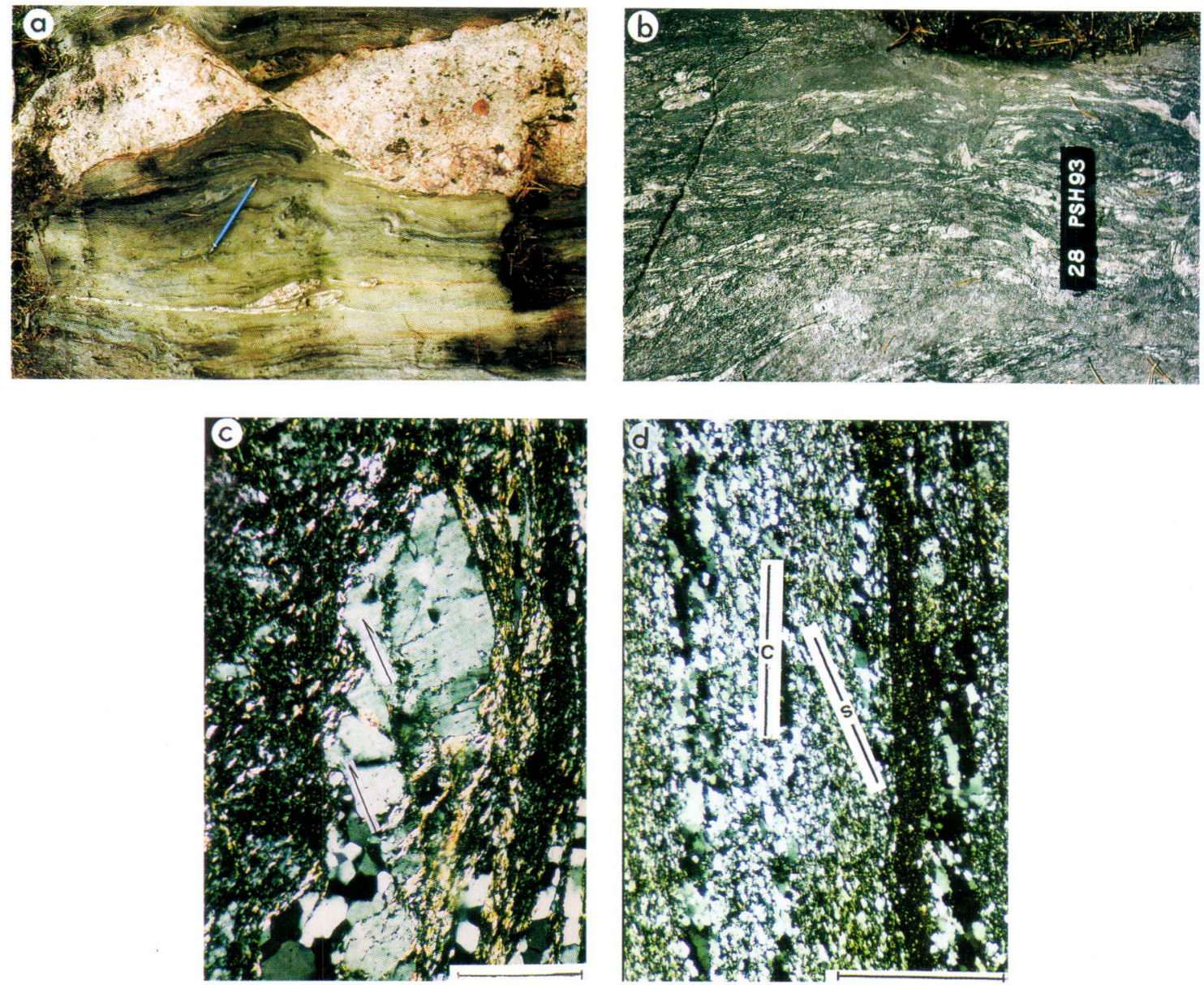

Fig. 5. Outcrop photographs and photomicrographs of late $D_{3}$ and $D_{4}$ shear zones. a) Dextral sense of shear is indicated by folding (centre), stair-stepping of mylonitizised granite vein (centre-down) and displacement of granite dyke. Pencil is $15 \mathrm{~cm}$ long. Tortinmäki, map sheet 1044 12, $x=6732750, y=1576900$. b) Pseudotachylites in the Vellua $D_{4}$ Shear Zone (dark areas in the upper part of the figure). Scale bar $12 \mathrm{~cm}$ long. Kalanti, map sheet 1042 12, $x=6737100, y=1531800$. c) Photomicrograph from the Mynälahti mylonite. Section parallel to the stretching lineation and normal to the foliation, view looking south. Synthetic microfaults in Kfs porphyroclast and $S$-C structure to the right of it show E-side down sense of shear (sinistral in figure). Scale bar $1 \mathrm{~mm}$ long. Livonsaari, map sheet $104210, x=6711350, y=1539020$. d) Photomicrograph from the Paimio mylonite. Section parallel to the stretching lineation and normal to the foliation, view looking north. $S$-C structure and oblique grains show E-side down sense of shear (dextral in figure). Scale bar $1 \mathrm{~mm}$ long. Paimio, map sheet 2022 01, x=6713000, $y=2428450$.

younger generation of overturned, reclined or recumbent, roughly northward vergent folds (Fig. 3). This is the reason for the wide variation in foliation orientations presented on the map by Hietanen (1943). Trends of the fold axes of the later folding show a large scatter, although east and south- east predominate. This may indicate that the fold axes initiated obliquely to the direction of transport and/or were subsequently rotated.

In one subhorizontal, highly strained zone the early flat-lying foliation is refolded by tight to isoclinal, reclined or recumbent folds. Fold axes 
plunge towards the ESE and the mineral lineation is parallel to the fold axis. The lineation is defined by aggregates of biotite+sillimanite, and is more pronounced than in adjacent areas. Tourmalinebearing pink granite intrudes this shear zone. Fold axes and lineations probably indicate a top-toWNW tectonic transport direction. This high strain zone is interpreted as an overthrust (Fig. 3) and the associated deformation is correlated with the $\mathrm{D}_{3}$ deformation described above. The zone is rather poorly exposed and, because no low altitude aeromagnetic data exist in this area, its continuation towards both the east and west remains unclear. On the northern side of the shear zone the $\mathrm{D}_{3}$ structures are upright. Recumbent $\mathrm{F}_{3}$ folds were also found in the southernmost part of the study area, at Parainen (Fig. 4d), possibly indicating the presence of other $\mathrm{D}_{3}$ thrusts.

\section{Late $\mathbf{D}_{3}$ shear zones}

Late $D_{3}$ shear zones differ from the earlier $D_{3}$ shear zones described above by being more localized, usually a few metres to a few tens of metres wide. One exception is the long, E-W trending, subvertical Riihikoski shear zone in the NE part of the study area that in places is more than one hundred metres wide (Fig. 3). Late orogenic granites affected by these shear zones were deformed into protomylonites, mylonites and ultramylonites. The presence of chlorite and epidote in some places indicates retrograde metamorphic conditions. The three shear zones north of Vahto (Fig. 3) all show a right-lateral sense of shear in a horizontal section. The observation in Fig. 5a is made outside the mylonitic zone with highest strain, but it is interpreted to reflect the same sense of shear as the main zone. The kinematics of this particular shear zone are, however, equivocal since three different directions of movement have been reported. Fifteen kilometres east of this locality, Nironen (1999) describes sinistral S-C structures and some $60 \mathrm{~km}$ east along the same shear zone at Somero, there called the Painio Shear Zone, Stel et al. (1989) observed vertical, south side up movement. This implies that the kinematics within the zone deviated from the ideal plane strain and simple shear conditions.

On a road cut at Riihikoski along Highway 41 $(x=6733000, y=2421750$; Fig. 3), mylonites and ultramylonites are well exposed. Pink granite dykes that resemble the late orogenic granites cut across the mylonitic foliation, but become subsequently deformed themselves. Hence, this shear zone has been active before and after the emplacement of the dykes. Although the late $\mathrm{D}_{3}$ shear zones were active later than the main $\mathrm{D}_{3}$ deformation described above, the dextral kinematics and their relationship to late orogenic granites suggest that they fit into the same compressional tectonic regime.

\section{$\mathrm{D}_{4}$ shear zones}

$\mathrm{D}_{4}$ structures are localized fault zones crosscutting and locally reorienting the older structures as well as the late orogenic granites. Their general trend varies from N-S to NE-SW. Other directions also exist but they are interpreted as conjugates to the main direction (Fig. 3). The most prominent of these faults are clearly visible as magnetic minima on aeromagnetic maps and as lineaments on topographic maps and satellite images. The innermost parts of the shear zones are seldom exposed but are mostly covered by glacial sediments. These shear zones are a few metres to tens of metres wide, but in places several may occur together forming rather wide zones.

Both ductile and brittle structures are present, commonly within the same shear zone. Ductile parts of the shear zones exhibit a well-developed subvertical mylonitic foliation with a vertical stretching lineation. Granitic rocks show mylonitic textures with reduced grain size, quartz ribbons and porphyroclast development. Feldspars also show brittle deformation. Pseudotachylites are locally present, e.g. in the Vellua Shear Zone (Fig. $5 b)$. This suggests that shearing began at the brittle-ductile transition but continued into the brittle field. Figs. 5c and 5d show details from the Mynälahti and Paimio Shear Zones. Microstructures such as S-C structures, asymmetric porphyroclasts, mica fish and oblique grains, show that both the Mynälahti Shear Zone and the Paimio 

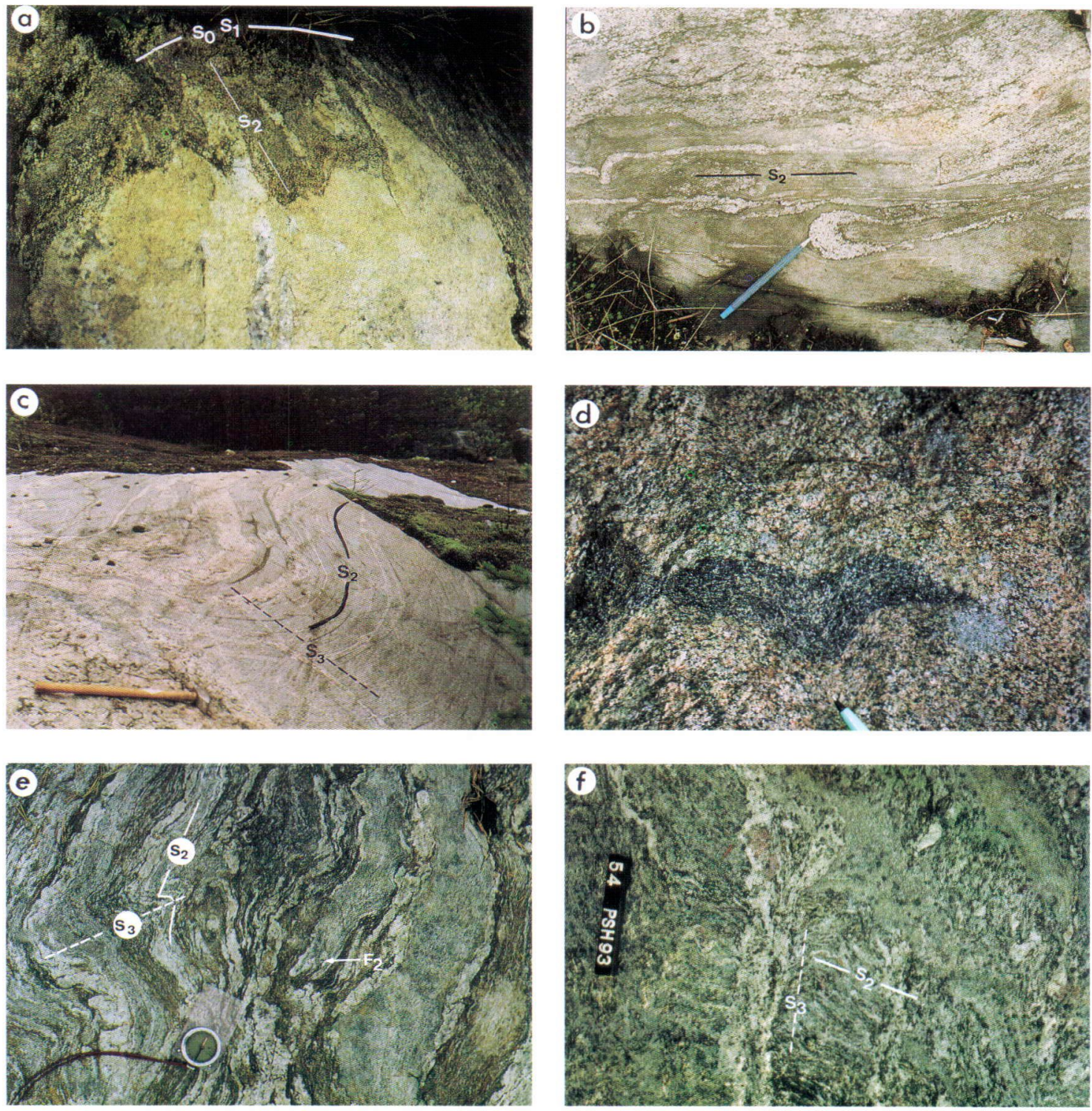

Fig. 6. Relationships between magmas, melts and deformation. a) Tonalite dyke intrudes an $F_{2}$ fold hinge, sending apophyses along the axial plane foliation $\left(S_{2}\right)$. Field of view $1 \mathrm{~m}$ wide. Kalanti, map sheet 1131 10, $x=6741400$, $y=1532600$. b) Contact of the ca. 1.87 Ga (van Duin 1992) Vahto tonalite (upper part of the figure) and psammitic country rock. Narrow tonalite veins from the main intrusion are folded by $F_{2}$, fill the $F_{2}$ fold hinges and intrude along the axial planes of isoclinal $F_{2}$ folds (pen is $15 \mathrm{~cm}$ long). $S_{2}$ foliation is also developed in the tonalite. Masku, map sheet 1044 07, $x=6715300, y=1564500$. c) Gneissic $S_{2}$ foliation, defined by mafic schlieren and enclaves in tonalite folded by open $F_{3}$, with coarse-and medium-grained granite intruded along the axial plane of $F_{3}$ and pre-existing $S_{2}$ foliation. Hammer is $60 \mathrm{~cm}$ long. Masku, map sheet 1044 07, x=6715800, $y=1561500$. d) $S_{2}$ foliation in enderbite ( $E-W$ in the picture), deformed by $F_{3}$ crenulation. Mafic enclaves are deformed in the same way as in tonalites, cf. Fig. 6c. Pencil for scale. Naantali, map sheet 1043 06, x=6706300, $y=1551000$. e) Lithological layering deformed by isoclinal $F_{2}$ fold. Leucosomes were developed during $D_{2}$ and deformed by open $F_{3}$. Compass for scale.Vellua, map sheet 104212 , x=6737400, y=1531800. f) Patchy leucosomes, often garnet and cordierite bearing, developed in the axial plane of $F_{3}$ fold. Metapelite has a well-preserved bedding structure. Scale bar $12 \mathrm{~cm}$ long. Vellua, map sheet 1131 10, $x=6741700, y=1533000$. 

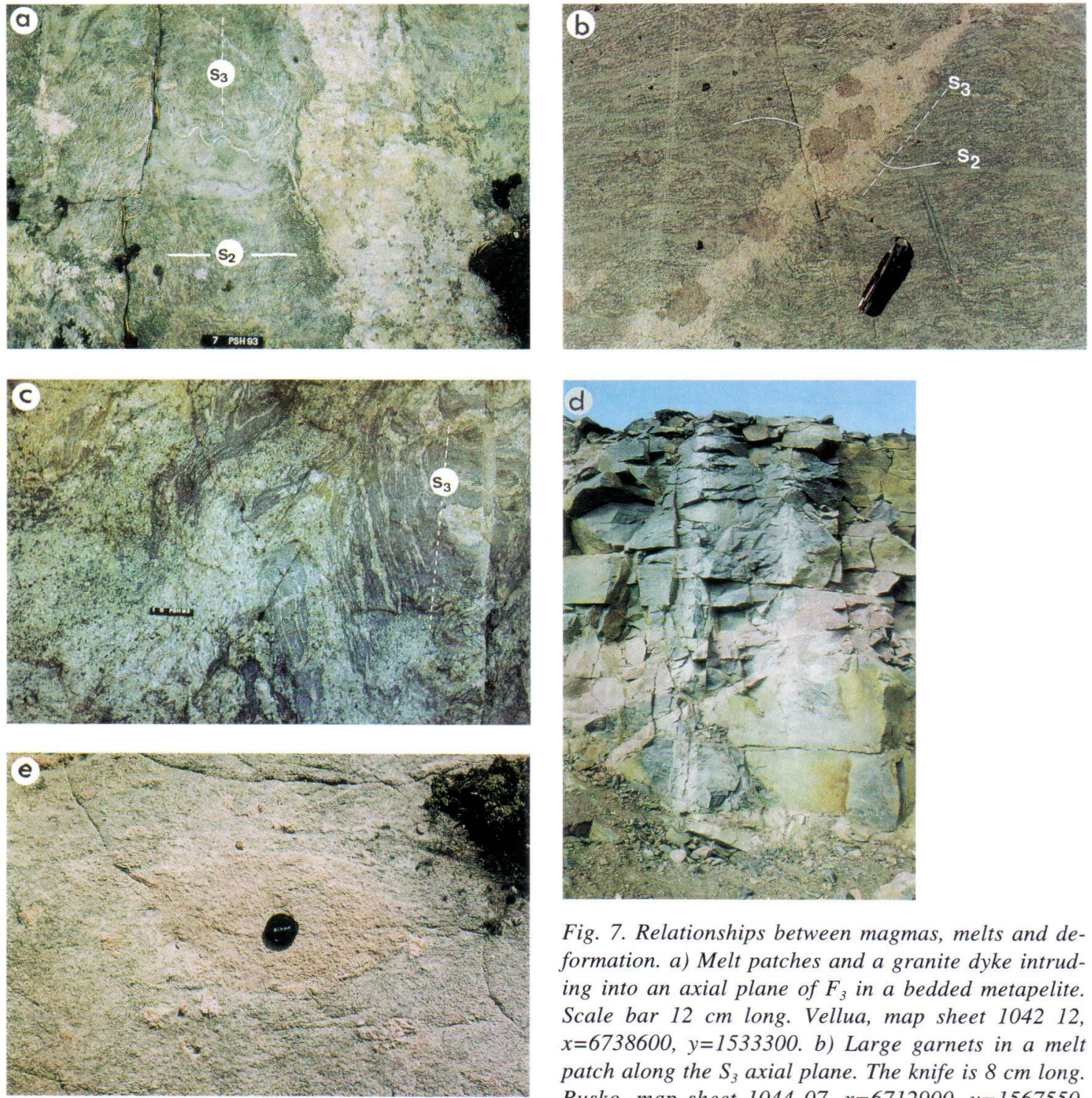

Fig. 7. Relationships between magmas, melts and deformation. a) Melt patches and a granite dyke intruding into an axial plane of $F_{3}$ in a bedded metapelite. Scale bar $12 \mathrm{~cm}$ long. Vellua, map sheet 1042 12, $x=6738600, y=1533300$. b) Large garnets in a melt patch along the $S_{3}$ axial plane. The knife is $8 \mathrm{~cm}$ long. Rusko, map sheet 1044 07, $x=6712900, y=1567550$.

c) Abundant leucosome brecciating $F_{3}$ fold structures in granulite. Restitic $F_{3}$ fold hinges are preserved in the garnet-bearing melt. Lemu, map sheet 1042 12, $x=6738600, y=1533300$. d) Contact between postorogenic Urusvuori diorite and granite. Granitic dykes apparently cut the diorite. Height of the quarry wall is 5 metres. Map sheet $104410, x=6710500, y=1571750$. e) Granite fragments (under the lens cap) in diorite. Same locality as in Fig. $7 d$.

Shear Zone had E-side down movement. The sense of shear of the Vellua zone could not be determined.

Similar N-S oriented shear zones to the west of the study area, in the Åland archipelago (Fig. 2), are spatially associated with the postorogenic $\mathrm{Se}$ - glinge and Åva intrusions (1.785 and $1.80 \mathrm{Ga}$ respectively, Vaasjoki 1996). It is therefore assumed that the age of the intrusions gives the age of the shear zone activity (Branigan 1987). On the other hand, the similar NE-SW trending PorkkalaMäntsälä shear zone, $20 \mathrm{~km}$ northwest of Helsin- 


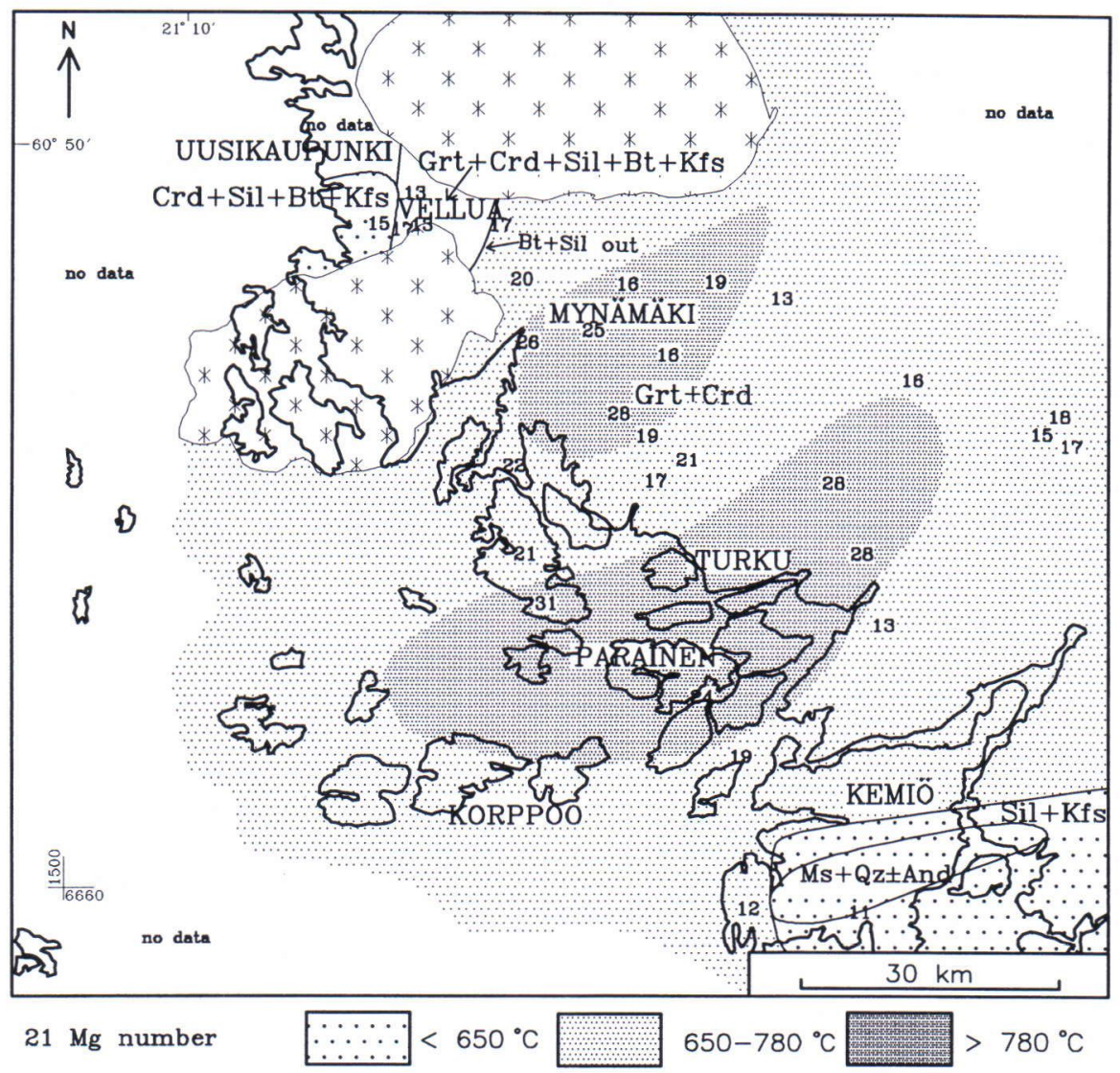

Fig. 8. Metamorphic map of the Turku area. The temperature distribution is based on the garnet-cordierite thermometry of Gerya and Perchuk (1992). The Mg numbers are for garnet. Data for Kemiö, SW part of the map, is from Dietvorst (1982).

ki (Fig. 1), was active as late as $1.64 \mathrm{Ga}$ during the intrusion of the Obbnäs rapakivi granite (Vaasjoki 1977, Heeremans et al. 1996). Therefore, it is possible that the shear zones in the Turku area were also reactivated during intrusion of the rapakivi granites.

\section{Post- $\mathrm{D}_{4}$ deformation}

The anorogenic Kolinummi Anorthosite (Fig. 2) is locally sheared (Väisänen et al. 1994). Branigan (1987) also reports local faulting and shearing that postdates even the latest phases of deformation described above. This indicates localized tectonic activity after the main Svecofennian orogeny, probably during the formation of the
Mesoproterozoic grabens filled with Jotnian sandstones.

\section{METAMORPHIC ZONES, ASSEMBLAGES AND TEXTURES OF THE TURKU DOMAIN}

On the basis of mineral assemblages and compositions, grain size and the amount of leucosome in metapelitic rocks, the Turku domain is divided into five metamorphic zones. These are the crdsil-bt-kfs zone, south of Uusikaupunki, the Vellua grt-crd-sil-bt-kfs zone, the grt-crd zone without coexisting biotite and sillimanite and the Mynämäki and Parainen high-temperature granulites (Fig. 8). The metamorphic zones of the Kemiö 
area are described by Dietvorst (1982).

The lowest grade rocks in the Turku domain occur on the western side of the NNE striking Vellua Shear Zone (Fig. 3). Supracrustal rocks are mostly fine-grained (average grain size about $0.5 \mathrm{~mm}$ ) granoblastic metasedimentary rocks with the assemblage bt-pl-kfs-qtz (mineral abbreviations after Kretz 1983) and rare garnet. These metasedimentary rocks contain aluminous layers with assemblages ms-bt-sil-kfs-pl-qtz \pm crd, occasionally grt-bt-sil-pl-qtz. These layers are often sheared and migmatized, with leucosomes making up to 10-20 vol\% of the rock (Fig. 6e). Pegmatitic granite sheets are up to several hundred metres wide.

In Al-rich rocks, cordierite is an alteration product of sillimanite, having prismatic sillimanite inclusions. Muscovite occurs both aligned parallel to the $S_{2}$ foliation and as randomly oriented grains which overgrow $\mathrm{F}_{3}$ folds, which indicates that it is a late retrograde phase. Coarse muscovite flakes are commonly intergrown with cordierite, biotite and $\mathrm{K}$-feldspar, having also sillimanite inclusions (Fig. 9a). This indicates that muscovite and cordierite were either produced or consumed in the divariant KFMASH reaction

$$
b t+s i l+q t z+V=c r d+m s
$$

or in the univariant reaction

$$
\mathrm{ms}+\mathrm{crd}+\mathrm{qtz}=\mathrm{bt}+\mathrm{ksp}+\mathrm{sill}+\mathrm{V}
$$

(provided that muscovite was Fe bearing).

On the basis of Fig. 9a it is difficult to interpret the reactants and products of the reaction, in any case all the minerals mentioned in (1a) are involved. Muscovite also replaces K-feldspar in Al-rich rocks, being therefore partly formed in the reaction

$$
\text { (2) } \mathrm{kfs}+\mathrm{sil}+\mathrm{V}=\mathrm{ms}+\mathrm{qtz} \text {. }
$$

In sheared layers with leucosome, feldsparbearing domains have euhedral plagioclase and $\mathrm{K}$ feldspar grains with interstitial quartz. Some Kfeldspars also have small, randomly oriented, id- iomorphic plagioclase inclusions. These textures are typically magmatic, indicating the presence of melt. Myrmekite with coarse quartz vermicules is common on plagioclase grain rims.

Coarse muscovite disappears from unsheared rocks $\sim 1 \mathrm{~km}$ west of the Vellua Shear Zone, and there is a narrow zone where peraluminous metasediments have the assemblage bt-sil-crd-pl$\mathrm{qtz} \pm \mathrm{kfs}$. Biotite and sillimanite coexist. Cordierite occurs as large grains (3-10 mm) which have either few or abundant, randomly oriented biotite and quartz inclusions, with sillimanite inclusions only near the rims of the grains. These cordierites may have crystallized before the reaction

$$
\mathrm{bt}+\mathrm{sil}+\mathrm{qtz}=\mathrm{crd}+\mathrm{kfs}+\mathrm{V}(\text { or melt })
$$

which produced cordierite coronas between biotite and sillimanite (Fig. 9b). Metapelites in this zone have small volumes, 2-3 vol\%, of coarse-grained granitic leucosome veinlets, indicating that melting had begun. Myrmekite with coarse quartz vermicules also occurs in these rocks at plagioclase rims.

In the eastern side of the Vellua Shear Zone, garnet appears in peraluminous metasedimentary rocks in the assemblage grt-crd-bt-sil-kfs-pl-qtz. Spinel is sometimes present as inclusions in cordierite or garnet, but never coexists with quartz. Metapelites of the same grade occur also in the southern part of the study area at Korppoo (Fig. 8). These have normally less than $5 \%$ leucosome and biotite and sillimanite still coexist. Bedding structures are well preserved. Patchy leucosomes are commonly garnet and cordierite bearing (Fig. 6f). The abundance of garnet in the mesosome varies from almost garnet-free in Mg-rich layers to about $10-15$ vol\% garnet in more Fe-rich layers. In sillimanite-rich layers, garnet and cordierite always have abundant sillimanite inclusions (Fig. 9c), whereas in granoblastic Al-poorer layers there are subhedral coarse (up to $5 \mathrm{~mm}$ ) cordierites which have biotite and quartz inclusions but no sillimanite. In the presence of sillimanite, garnet rims have commonly been altered to cordierite (Figs. 9c and 9d). In places, garnets with sillimanite inclusions have altered along fractures to green or pale brown 

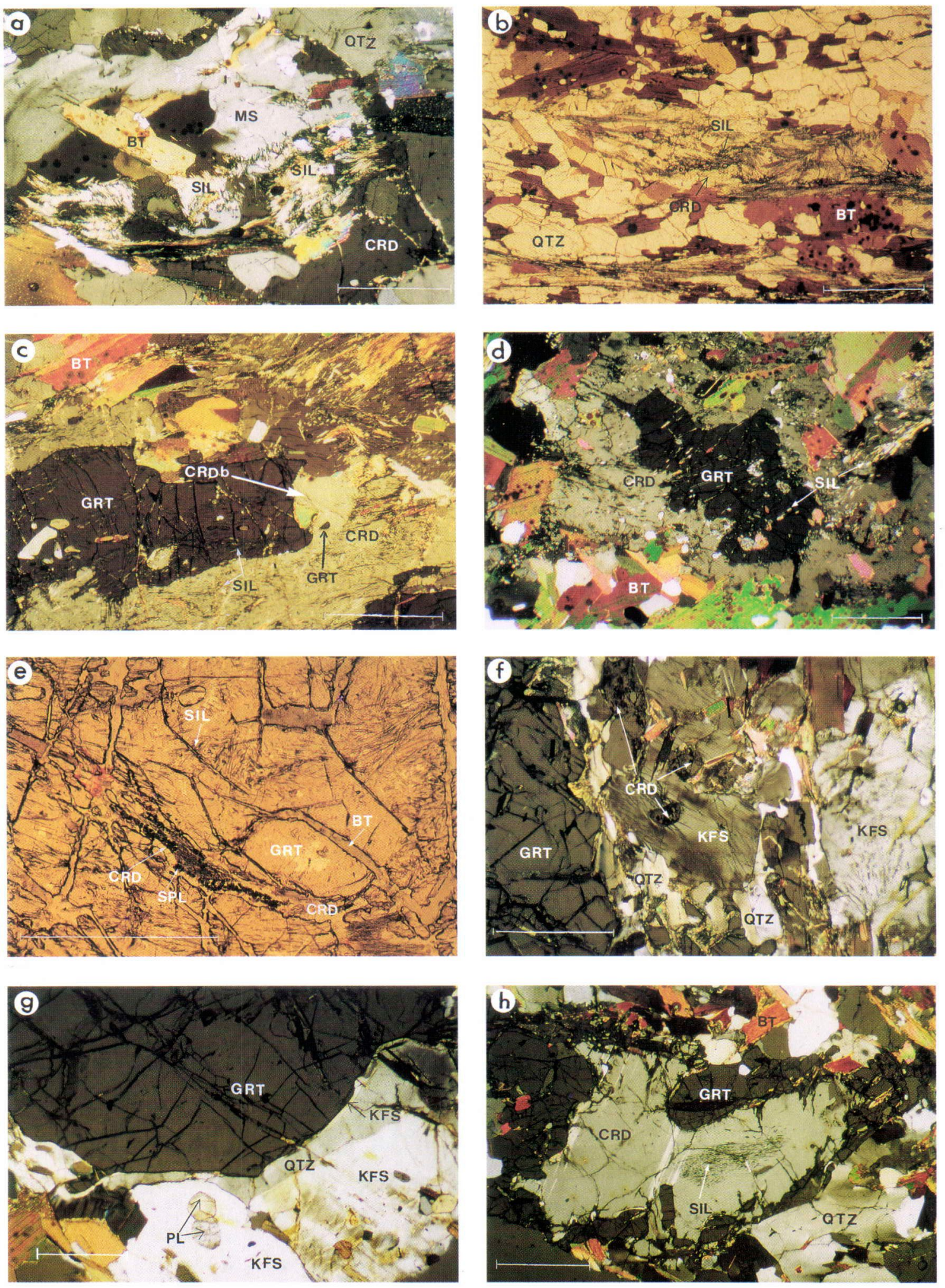

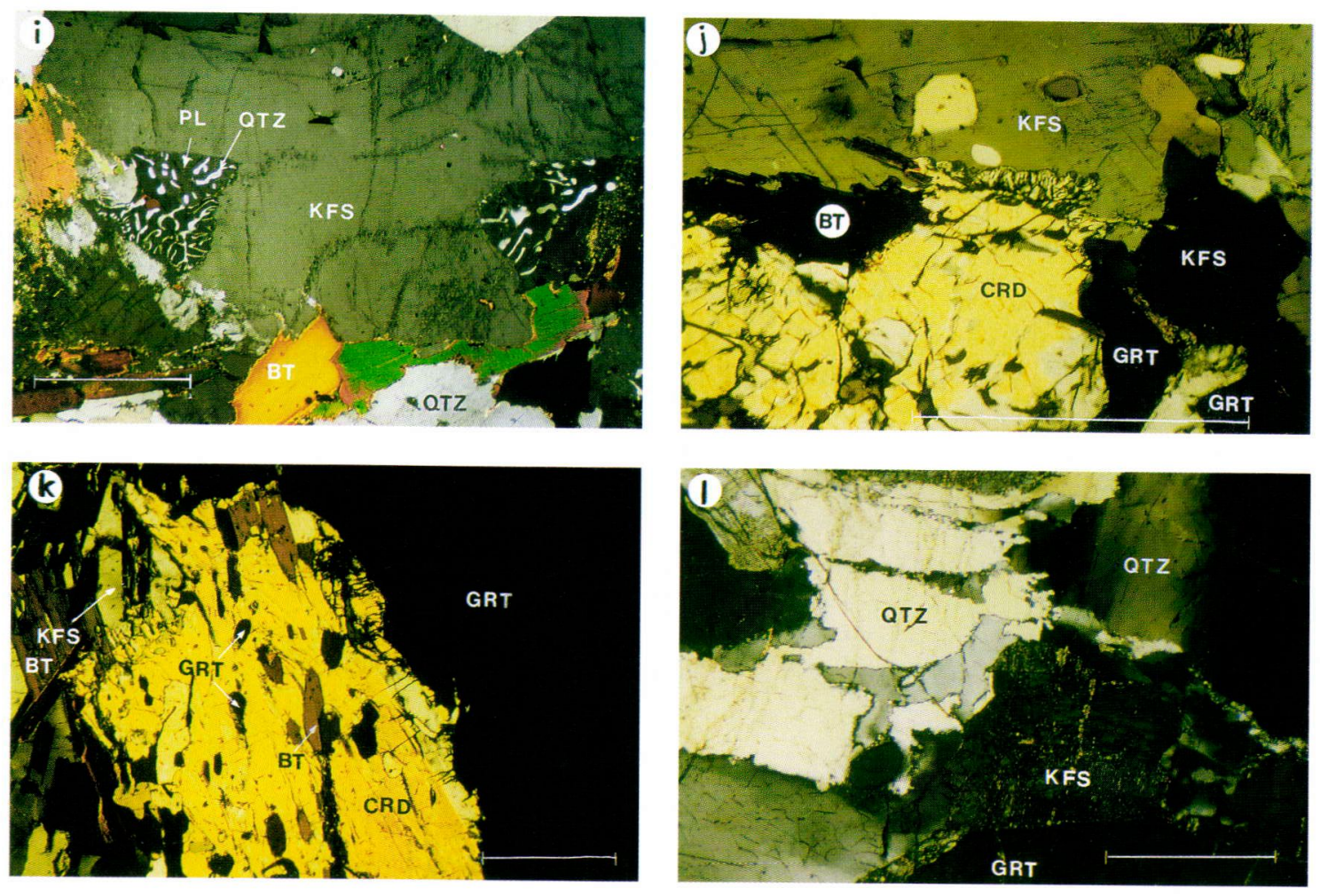

Fig. 9. Reaction textures. Scale bar in each figure $0.5 \mathrm{~mm}$ long. a) Biotite and sillimanite forming cordierite and muscovite, Vellua crd-sil-bt-kfs zone (Fig. 8). Map sheet 1042 12, $x=6738750, y=1530100$. b) Biotite and sillimanite forming cordierite, Vellua crd-sil-bt-kfs zone. Map sheet 1131 10, x=6740050, y=1532750. c) Garnetcordierite assemblage in the Vellua grt-crd-sil-bt-kfs zone. Garnet and cordierite have optically continuous sillimanite inclusions, indicating that they were formed in reaction (4). The right edge of garnet further reacted forming second generation cordierite $(C R D b)$ in reaction (5), which is indicated by cordierite without sillimanite inclusions, having tiny garnet inclusions, and the shape of the pre-existing garnet grain. Map sheet 1131 10, $x=6741100$, $y=1533200$. d) Garnet decomposing into cordierite, Vellua grt-crd-sil-bt-kfs zone. Map sheet 1131 10, $x=6741100$, $y=1533200$. e) Garnet decomposing along fractures into greenish biotite, cordierite and hercynite, Vellua grtcrd-sil-bt-kfs zone. Map sheet 1042 12, x=6737400, $y=1532200$. f) and g) Garnets and feldspars with well-developed crystal faces against quartz in migmatite mesosomes, indicating the existence of melt. Masku, map sheet 1044 07, $x=6714950, y=1567950$. h) Garnet corona on cordierite. Rusko, map sheet $104407, x=6714950$, $y=1567950$. i) Myrmekite replacing K-feldspar in migmatite leucosome, Mynämäki granulite. Map sheet 1044 06, $x=6727200, y=1555350 . j)$ and $k$ ) Garnet and $K$-feldspar forming cordierite and biotite, Mynämäki granulite. Map sheet 1044 06, $x=6727200, y=1555350$. l) Mortar texture in granulite leucosome, Mynämäki granulite. Map sheet $104408, x=6722670, y=1564700$.

biotite, cordierite and green spinel, which replaces sillimanite (Fig. 9e). These textures indicate reactions
(4) $\mathrm{bt}+\mathrm{sil}+\mathrm{qtz}=\mathrm{grt}+\mathrm{crd}+\mathrm{kfs}+\mathrm{V}$ (or melt),
(5) $\mathrm{grt}+\mathrm{sil}+\mathrm{qtz}=\mathrm{crd}$,

(6)

grt + sil $=\mathrm{crd}+\mathrm{spl}$

The spinel-producing reaction at Vellua may have been caused by contact metamorphism of the Vehmaa rapakivi granite, because it is restricted to exposures within $2-3 \mathrm{~km}$ of the contact. Spinel is abundant at the contact zones where rapa- 
kivi granite has caused extensive melting.

A common assemblage in melt patches is grtbt-pl-kfs-qtz \pm crd. Some leucosome patches only have bluish grey cordierite instead of garnet. Cordierite is mostly fresh but, in places, pinitized. Monazite is a common accessory phase and tourmaline is sometimes present. Garnets and K-feldspars are generally up to $1.5 \mathrm{~cm}$ in grain size, but even larger poikilitic grains of garnet with abundant quartz inclusions are locally present. Cordierites are subidiomorphic having abundant quartz inclusions. Interstitial quartz occurs between idiomorphic or subidiomorphic, randomly oriented plagioclases. Myrmekite is common both in plagioclase and in $\mathrm{K}$-feldspar rims.

Towards the south and east of Vellua, the metamorphic grade increases progressively. Biotite-sillimanite contacts become increasingly rare and the volume of leucosome in metapelites increases. The area around the highest grade granulites in Fig. 8 is characterized by metapelites which still have rather well-preserved lithological layering, but the amount of leucosome is $10-20$ vol\% and migmatization is mainly stromatic (Figs. $4 a$ and c). The assemblage is grt-crd-bt-sil-pl-kfs-qtz, but sillimanite only occurs as inclusions in garnet and in cordierite. Biotite and sillimanite coexist only in some sillimanite- and biotite-rich layers. Garnet, cordierite and biotite are mostly aligned along the $\mathrm{S}_{2}$ foliation, although cordierite has a tendency to form subidiomorphic crystals with quartz inclusions. Commonly, garnet and cordierite are intergrown, and they have optically continuous biotite and sillimanite inclusions. K-feldspars commonly have biotite inclusion trails in all zones, which are oblique to the main foliation. Quartz locally forms interstitial films between poikilitic garnet, cordierite and K-feldspar which form crystal faces against quartz (Figs. 9f and 9g). Because this kind of texture is typically magmatic, it can be interpreted as evidence for melting reaction (4) (Vernon \& Collins 1988). Garnet rims are commonly replaced by cordierite. A rare texture where cordierite has a garnet corona is also observed (Fig. 9h). Cordierite rims are chloritized, and tiny, randomly oriented sillimanite needles have crystallized on cordierite rims, locally also andalusite together with biotite, suggesting the cooling reaction $\mathrm{crd}+\mathrm{kfs}+\mathrm{V}=\mathrm{and} / \mathrm{sil}+\mathrm{bt}+\mathrm{qtz}$. Tourmaline in places forms a melanosome-like dark rim on the leucosome veins.

According to our observations, granulites occur in two distinguishable domains, the Mynämäki domain in the north and the Parainen domain in the south (Fig. 8). These are highly migmatized rocks with up to $50-80$ vol\% of granitic leucosome. Between the two areas there are less migmatized areas with well-preserved bedding structures, which are almost totally destroyed in the granulites. The mesosome assemblage in the pelitic rocks is the same, grt-crd-bt-pl-kfs-qtz \pm sil, as in the lower grade gneisses, but the abundance and grain size of garnet increases (commonly 1-2 cm). Green spinel is locally present as inclusions in cordierite. Various migmatite types, metatexites, diatexites, stictolites (nomenclature after Mehnert 1971) occur (Figs. 7b, 10a and 10b). Large cordierite- and garnet-bearing coarse-grained granite bodies, tens to hundreds of metres in width, are common. In sillimanite-absent layers the texture is mostly granoblastic, whereas sillimanite-bearing layers always show a pronounced microscopic foliation, commonly with some shearing, which probably indicates deformation partitioning into less competent layers. Cordierite rims are altered to biotite, sillimanite and andalusite. Garnet rims are altered to cordierite and $\mathrm{K}$-feldspar rims are commonly replaced by myrmekite. Occasionally cordierite and K-feldspar form symplectitic intergrowths (Figs. 9i and 9j). Garnet rims are also altered to crd-bt-qtz symplectites (Fig. 9k) indicating the cooling reaction

\section{(7) $g r t+k f s+V=c r d+b t+q t z$.}

Leucosomes commonly contain idiomorphic garnet and cordierite grains, up to several centimetres in diameter (Figs. 10c and 10d), normally occurring close to the restitic schlierens where they may form aggregates of several crystals. Garnet may be poikilitic with abundant quartz inclusions, but euhedral, almost inclusion-free garnets are also common. Primary brown biotite is only an accessory phase in most leucosomes. Silliman- 

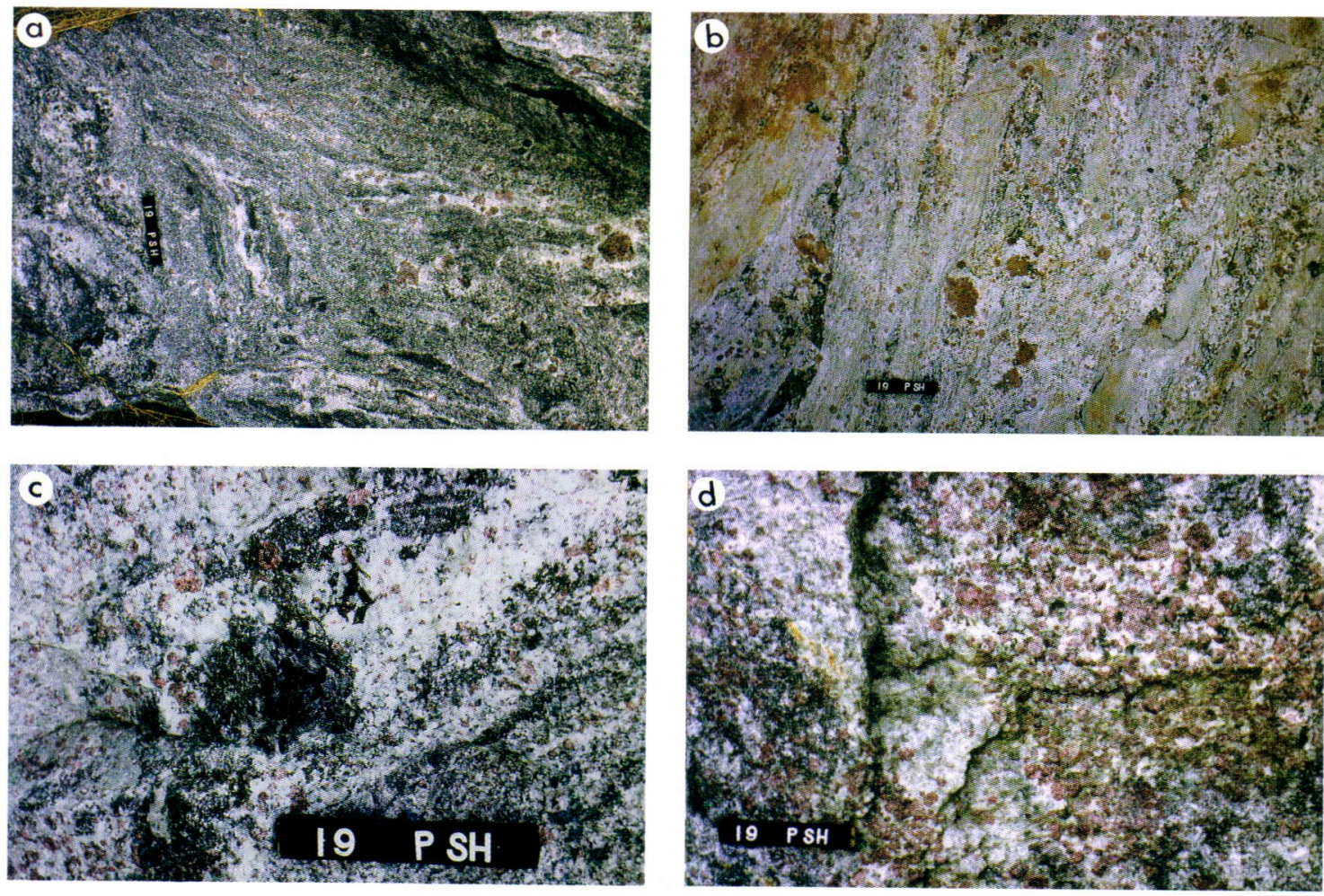

Fig. 10. Migmatite types in the Parainen granulite in the road cuts of the motorway. Scale bar $12 \mathrm{~cm}$ long. Map sheet 1043 12, $x=6704100, y=1581000$. a) and b) Diatexites with large garnet crystals surrounded by felsic haloes. c) A large cordierite crystal in leucosome. d) Garnet-rich leucosome with large garnets.

ite grains, much coarser than in mesosomes, are present in the matrix where they may be overgrown by garnet. As in mesosomes, cordierite is altered at its rims and in fractures to almost isotropic pinite, green biotite and andalusite or sillimanite. In leucosomes, large idiomorphic plagioclase and $\mathrm{K}$-feldspar crystals with interstitial quartz are commonly randomly oriented. Graphic textures with macroscopically observable quartz-feldspar intergrowths are common. Most leucosomes seem to have been deformed in a semiductile manner. Quartz shows undulatory extinction and the quartz-feldspar contacts have been recrystallized into fine-grained aggregates (Fig. 91).

\section{MINERAL COMPOSITIONS OF METAPELITES}

The mineral compositions of the metapelites correlate well with the observed metamorphic zonation based on mineral assemblages, degree of migmatization, grain size and the preservation of primary bedding structures. Ferromagnesian minerals become generally more $\mathrm{Mg}$ rich with increasing grade, but there are differences due to mineral reactions. However, no compositional differences between different garnet generations with respect to deformation (syn$\mathrm{D}_{2}$, syn- $\mathrm{D}_{3}$ minerals) within the various metamorphic zones could be detected. The compositions of garnets, cordierites, biotites and spinels are presented in AFM diagrams in Fig. 11. In the Mynämäki and Parainen granulites the garnet compositions are highly variable, which may be due to compositional changes during cooling. Exposures within the granulites but with lower garnet $\mathrm{Mg}$ numbers were nevertheless classified as granulites on the basis of similar extent of melting, abundance of garnet and absence of primary bedding structures. 

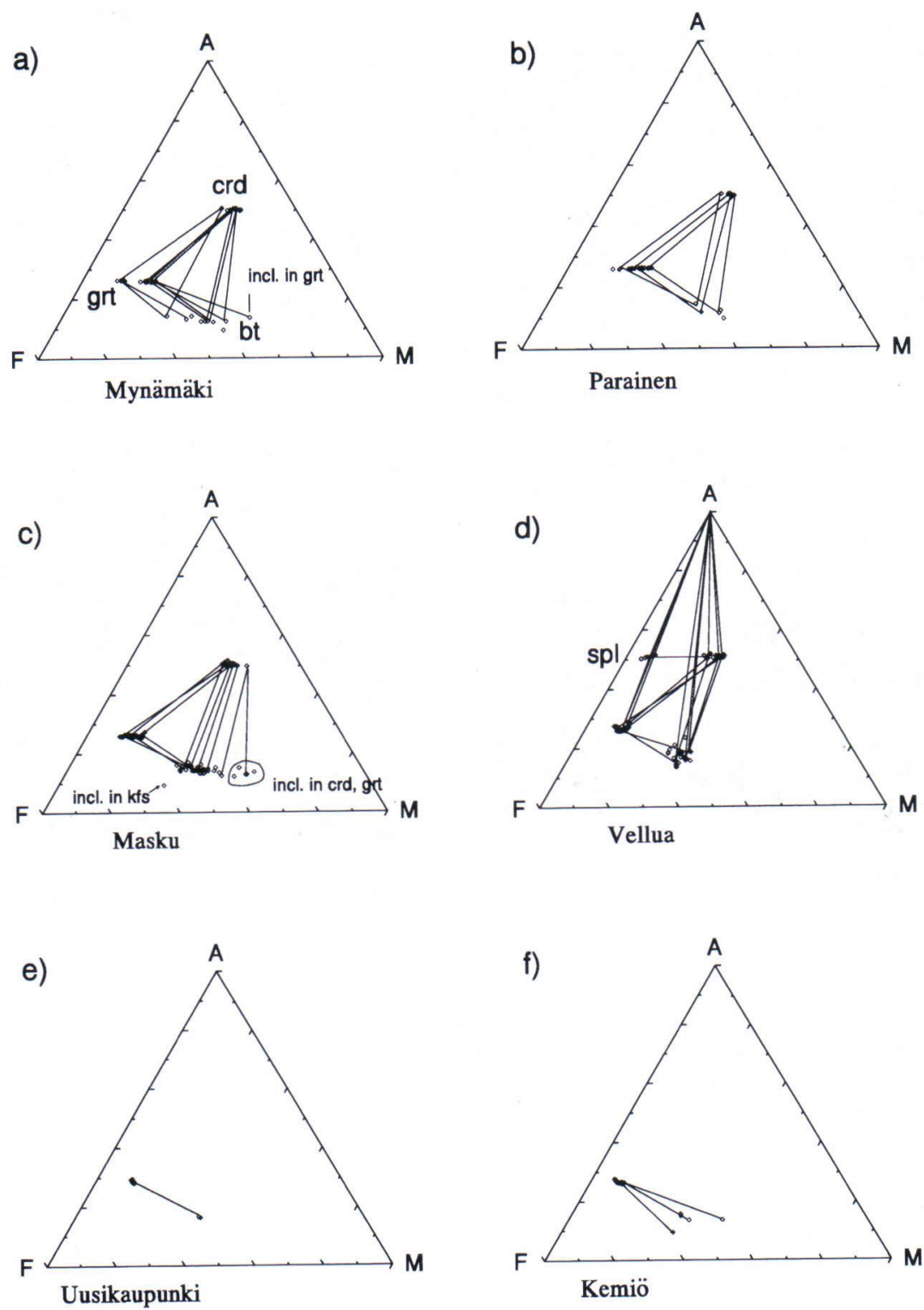

Fig. 11. AFM diagrams showing the mineral core compositions, projected from $K$-feldspar and quartz. Spinel never coexists with quartz, but it is presented in the figure to show its $\mathrm{Fe} / \mathrm{Mg}$ ratio. $\mathrm{A}=\mathrm{Al}_{2} \mathrm{O}_{3}-\mathrm{K}_{2} \mathrm{O}, \mathrm{F}=\mathrm{FeO}, \mathrm{M}$ $=\mathrm{MgO} . a$ ) and b) Mynämäki and Parainen granulites; c) garnet-cordierite gneisses surrounding the Mynämäki granulite area; d) Vellua garnet-cordierite-biotite-sillimanite gneisses; e) garnet-biotite gneisses in the crd-btsil-kfs zone north of the Vehmaa rapakivi granite; f) garnet-biotite gneisses in Kemiö.

\section{Analytical procedure}

Mineral analyses were made by Mr. Lassi Pakkanen at the Geological Survey of Finland with a Cameca-Camebax SX50 microprobe. Beam current was $20 \mathrm{nA}$ and acceleration voltage $15 \mathrm{kV}$. Beam diameter was 1 micron for garnet,
15 microns for $\mathrm{K}$-feldspar and 5 mictons for other minerals. Natural standards and the ZAF correction program were used. Representative mineral analyses are presented in Appendix 1. 
a)

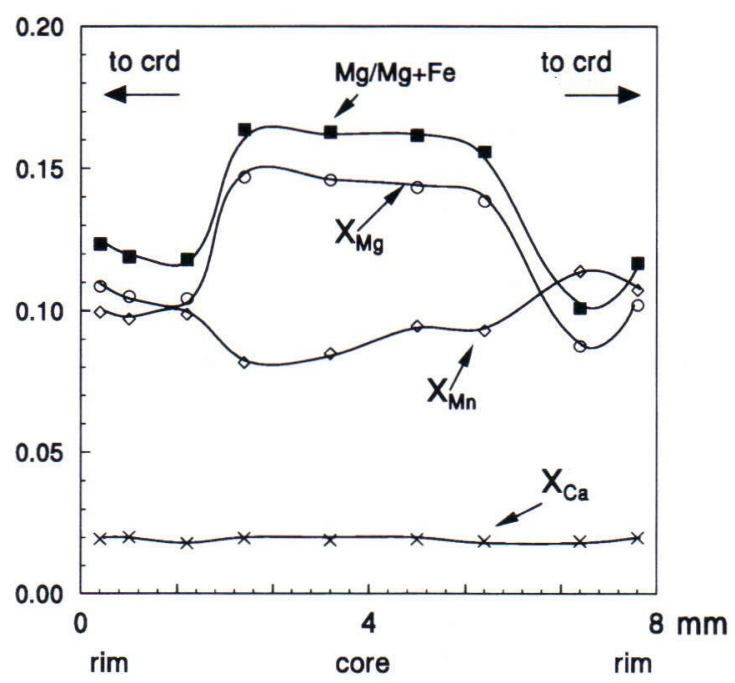

b)

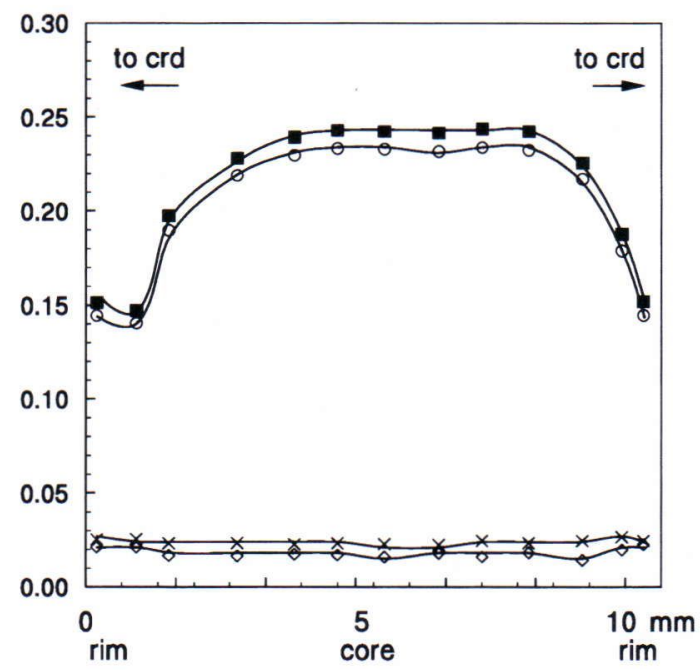

Fig. 12. Zoning profiles of garnets which have decomposed at their rims into cordierite. a) Vellua grt-crd-sil-btkfs zone. b) Mynämäki granulite zone. Symbols as in Fig. 12.a.

\section{Results}

\section{Garnet}

The $\mathrm{Mg}$ numbers $[\mathrm{Mg} /(\mathrm{Mg}+\mathrm{Fe})]$ of garnets for all the analysed specimens are presented in Fig. 8, representing averages of core compositions, 3-15 analysed points per grain.

In the crd-bt-sil-kfs zone north of the Vehmaa rapakivi granite there are a few Mn-rich garnets in biotite gneisses with grt-bt-pl-qtz assemblages. Their $\mathrm{X}_{\mathrm{Mg}}$ is $0.11-0.13$ and $\mathrm{X}_{\mathrm{Mn}}=0.13-0.17[\mathrm{Xi}=\mathrm{i} /(\mathrm{Fe}+\mathrm{Mn}+\mathrm{Mg}+\mathrm{Ca})]$. In the Vellua grt-crd-bt-sil-kfs zone the $X_{\mathrm{Mg}}$ of garnet is slightly higher than in the crd-bt-sil-kfs zone, being $0.10-0.15$ in garnet cores, and $\mathrm{X}_{\mathrm{Mn}}$ decreases to $0.03-0.05$. Where garnet has been altered into cordierite and biotite, it has a strong bellshaped zoning where $\mathrm{Mg}$ decreases towards the rims (Fig. 12a). In the migmatitic region between the Vellua grt-crdbt-sil-kfs zone and the Mynämäki granulite area where sillimanite occurs mostly as inclusions in garnet and cordierite, the $\mathrm{X}_{\mathrm{Mg}}$ of garnet cores is $0.15-0.19$ and the $\mathrm{X}_{\mathrm{Mn}}$ $0.01-0.05$. In two analysed specimens, the $\mathrm{Mg}$ content increases from core to rim.

In the Mynämäki and Parainen granulites the $X_{\mathrm{Mg}}$ of garnet cores is $0.23-0.30$, again showing a strong decrease of $\mathrm{Mg}$ content at the rims which have partly altered to cordierite. The $\mathrm{X}_{\mathrm{Mn}}$ is low, 0.01-0.03. The shape of the zoning profile differs from that in Vellua, not being so abrupt (Fig. 12b). In leucosomes the garnet compositions do not differ from those in the matrix. As observed by Hölttä (1986), high $\mathrm{Mg}$ contents ( $\mathrm{Mg}$ number 0.27-0.30) are preserved in garnets with grain size close to $1 \mathrm{~cm}$ or more, while the smaller garnets are poorer in $\mathrm{Mg}$. This may be caused by slow cooling during which diffusion has changed the composition of small garnets completely. Alternatively, the small garnets could be relics with compositions controlled by the garnet breakdown reaction during cooling. In the area between the Mynämäki and Parainen granulite areas the $\mathrm{X}_{\mathrm{Mg}}$ is $0.17-0.22$, increasing in the Parainen granulites again to $0.24-0.30$. The variation in $X_{\mathrm{Ca}}(0.02-0.04)$ of garnet is small in all areas.

\section{Cordierite}

The $\mathrm{X}_{\mathrm{Mg}}$ of cordierite $[\mathrm{Mg} /(\mathrm{Mg}+\mathrm{Fe})]$ is dependent on the reaction in which cordierite formed. In the Vellua grt-crdbt-sil-kfs zone, the matrix cordierite not in contact with garnet has $\mathrm{X}_{\mathrm{Mg}}$ of $0.55-0.57$. Some cordierites which form reaction coronas between garnet and sillimanite are of the same composition but, more commonly, cordierite which is the breakdown product of garnet is more Fe rich than the matrix cordierite, with $\mathrm{X}_{\mathrm{Mg}} 0.49-0.54$. Cordierite which formed together with spinel in reaction (4) is the Fe richest, with $\mathrm{X}_{\mathrm{Mg}}$ 0.45-0.49. In the area between the Vellua Shear Zone and Mynämäki granulite, the $\mathrm{X}_{\mathrm{Mg}}$ of the matrix cordierite is $0.58-0.60$, and cordierite which is the breakdown product of garnet is again Fe rich with $\mathrm{X}_{\mathrm{Mg}}$ of 0.54 .

In the Mynämäki and Parainen granulites the $X_{\mathrm{Mg}}$ of mesosome matrix and leucosome cordierites is $0.64-0.70$, and in cordierites after garnet $0.57-0.62$. In the region between the Mynämäki and Parainen granulites, $\mathrm{X}_{\mathrm{Mg}}$ of matrix cordierites is $0.57-0.64$, cores being Fe enriched relative to the rims that have altered to biotite. In a $\mathrm{D}_{3}$ leucosome, the cordierite is $\mathrm{Mg}$ rich, $\mathrm{X}_{\mathrm{Mg}}$ being 0.69 . The $\mathrm{CaO}$ and $\mathrm{Na}_{2} \mathrm{O}$ contents are low in all the analysed cordierites, being $0-0.06$ and $0.1-0.3 \mathrm{wt} \%$, respectively. 


\section{Biotite}

The Mg numbers of biotites are $0.43-0.44$ in the crd-btsil-kfs zone north of the Vehmaa rapakivi granite, while the $\mathrm{TiO}_{2}$ contents vary from 1.7 to $1.9 \mathrm{wt} \%$. In the Vellua grt-crd-bt-sil-kfs zone, the $\mathrm{Mg}$ numbers of matrix biotites are $0.37-0.42$ and the $\mathrm{TiO}_{2}$ contents $1.6-3.3 \mathrm{wt} \%$. Biotites formed after garnet in reaction (4) are relatively Fe rich, with $\mathrm{X}_{\mathrm{Mg}}$ 0.34-0.36. Pale green biotites are Ti poor, $\mathrm{TiO}_{2}$ being 0.06-0.07 wt\%, whereas brown biotites formed in reaction (4) contain more $\mathrm{TiO}_{2}\left(0.64-2.65 \mathrm{wt} \% \mathrm{TiO}_{2}\right)$.

In the area surrounding the Mynämäki and Parainen granulites, the biotite $\mathrm{Mg}$ numbers are commonly $0.44-$ 0.47 , in garnetiferous melt patches slightly higher, $0.45-$ 0.50 . Biotite inclusions in garnet are $\mathrm{Mg}$ richest: $0.50-0.63$. Biotites which are inclusions in cordierite or in $\mathrm{K}$-feldspar all have $\mathrm{Mg}$ numbers of $0.37-0.39$. $\mathrm{TiO}_{2}$ contents are 2.1$3.1 \mathrm{wt} \%$ in inclusions and $2.6-4.3 \mathrm{wt} \%$ in matrix biotites.

In the Mynämäki granulites the $\mathrm{Mg}$ numbers of matrix biotites are $0.42-0.48$. In the high-grade $\mathrm{D}_{3}$ shear zones they are 0.49-0.51 and in leucosomes 0.55-0.63. Biotites with the highest $\mathrm{Mg}$ numbers are those which were altered from garnet. Biotite inclusions in $\mathrm{K}$-feldspars are $\mathrm{Mg}$ poor, with a $\mathrm{Mg}$ number of 0.35 . In all analysed biotites $\mathrm{TiO}_{2}$ varies from $2.7-4.3 \mathrm{wt} \%$. In the Parainen granulites the $\mathrm{Mg}$ numbers and $\mathrm{TiO}_{2}$ contents of the matrix biotites in mesosomes are $0.50-0.57$ and $3.7-4.2 \mathrm{wt} \%$, respectively.

\section{Spinel}

Spinels were analysed only in the Vellua grt-crd-bt-sil-kfs gneisses, where they were produced in reaction (6). They are Fe rich, $\mathrm{X}_{\mathrm{Mg}}$ being $0.07-0.10\left[\mathrm{X}_{\mathrm{Mg}}=\mathrm{Mg} /(\mathrm{Fe}+\mathrm{Mg}+\right.$ $\mathrm{Mn}+\mathrm{Zn})]$. $\mathrm{ZnO}$ content is $0.8-2.7 \mathrm{wt} \%$ and $\mathrm{Cr}_{2} \mathrm{O}_{3} 0.02-$ $0.4 \mathrm{wt} \%$.

\section{Plagioclase}

Within the Mynämäki and Parainen granulites, the $\mathrm{X}_{\mathrm{Ca}}[\mathrm{Ca} /$ $(\mathrm{Ca}+\mathrm{Na}+\mathrm{K})]$ of plagioclase is $0.26-0.29$, without an observable difference between leucosome and mesosome. In the other areas, the anorthite content is more variable, with $\mathrm{X}_{\mathrm{Ca}}$ being $0.21-0.35$. The $\mathrm{BaO}$ contents vary from 0 to 0.7 wt \% and $\mathrm{Rb}_{2} \mathrm{O}$ is about $1.1 \mathrm{wt} \%$ in all samples.

\section{K-feldspar}

No differences in K-feldspar compositions could be found between the various metamorphic zones, except for $\mathrm{BaO}$, which is $0.5-0.8 \mathrm{wt} \%$ in the Vellua grt-crd-bt-sil-kfs zone and $0.2-0.6$ wt\% elsewhere. The $\mathrm{X}_{\mathrm{K}}$ is $0.78-0.92, \mathrm{X}_{\mathrm{Ca}} 0-$ 0.6 and $\mathrm{X}_{\mathrm{Na}} 0.08-0.21$ in the analysed samples $[\mathrm{Xi}=\mathrm{i} /$ $(\mathrm{Ca}+\mathrm{Na}+\mathrm{K})] . \mathrm{Rb}_{2} \mathrm{O}$ is close to $1.1 \mathrm{wt} \%$ in all samples.

\section{THERMOMETRY AND BAROMETRY}

Metamorphic pressures, temperatures and water activities were calculated with the GEOPATH thermodynamic software (Gerya \& Perchuk 1992), and for comparison for selected samples with the THERMOCALC v.2.4 software (Holland \& Powell 1990). The results are presented in Appendix 2 and in Fig. 8. Because in many cases diffusion or garnet breakdown reactions might have changed the mineral compositions during cooling, only core compositions of minerals not in contact in thin section were chosen for thermobarometric calculations in order to estimate the peak temperatures and pressures.

For the only sample analysed in the crd-bt-sil$\mathrm{kfs}$ zone north of the Vehmaa rapakivi granite the garnet-biotite temperature is $626^{\circ} \mathrm{C}$. In the Vellua grt-crd-bt-sil-kfs gneisses, the garnet-biotite and garnet-cordierite temperatures are $660-730^{\circ} \mathrm{C}$ and the garnet-cordierite-sillimanite-quartz pressures are $3.7-4.9 \mathrm{kbar}$. The average pressures given by THERMOCALC are slightly lower, 3.5-3.7 kbar. In the area between the Vellua Shear Zone and Mynämäki granulites, temperatures increase to $705-770^{\circ} \mathrm{C}$ and pressures to $5.4-5.6 \mathrm{kbar}$. Similar temperatures and pressures were determined from the zone between the Mynämäki and Parainen granulites. The area of the Masku Riviera just on the southern side of the Mynämäki granulites (Fig. 4c) is an exception where temperatures and pressures given by thermobarometry are lower, $600-670^{\circ} \mathrm{C}$ and $3.2-4.2 \mathrm{kbar}$, although the area is strongly migmatized (Fig. 4c). Lower temperatures and pressures of $640-720^{\circ} \mathrm{C}$ and 3.7-4.7 kbar were also obtained in the area east and southeast of the Parainen and Mynämäki granulites even though these areas are more intensely migmatized than the Vellua garnet-cordierite gneisses.

The highest garnet-cordierite(-sillimanite-quartz) temperatures and pressures in the Mynämäki and Parainen granulites are $800-825^{\circ} \mathrm{C}$ and $6.3-6.7$ kbar. These are given by core compositions of the largest analysed garnets while smaller garnets and those with rims strongly altered to cordierite normally give lower temperatures and pressures (730$\left.770^{\circ} \mathrm{C}, 5.3-5.9 \mathrm{kbar}\right)$. Garnet-biotite temperatures are systematically lower than garnet-cordierite temperatures, which indicates that biotites were reequilibrated during cooling. This also causes high standard deviations in the THERMOCALC results 


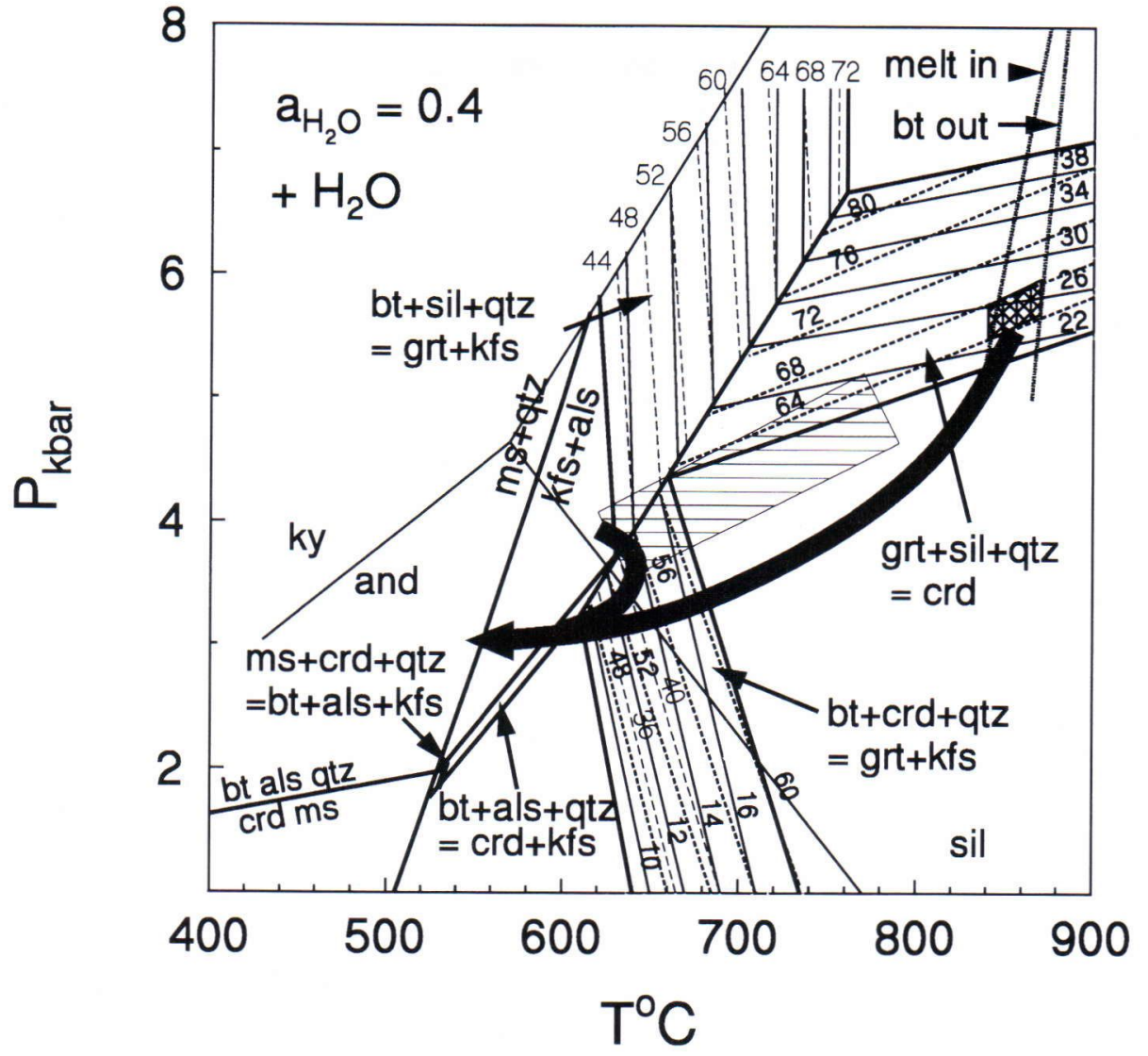

Fig. 13. A pseudosection in the KFMASH system for the given whole rock composition (see text), showing the positions of the univariant reaction $b t+s i l+q t z=c r d+g r t+k f s+V$ and divariant reactions $b t+s i l+q t z=$ $g r t+k f s+V, b t+s i l+q t z=c r d+k f s+V, b t+c r d+q t z=g r t+k f s+V$ and $c r d=g r t+s i l+q t z+V . T h e$ isopleths with numbers show the Mg numbers of garnet (solid lines), cordierite (heavy dashed lines) and biotite (light dashed lines). The rectangle filled with horizontal lines is for the metamorphic field gradient from Vellua to the areas surrounding the highest grade granulites, based on the compositions of garnet and cordierite. The smaller, hatched rectangle shows the PT conditions for the Mynämäki and Parainen granulites on the basis of their garnet and cordierite compositions. The two PT paths are for these granulites and for the Vellua crd-bt-sil$k f s$ gneisses. The melt-in and biotite-out curves are for fluid-absent biotite melting after Carrington and Harley (1995).

and relatively low average pressures and temperatures. However, because both garnet and cordierite compositions are clearly more magnesian in the Mynämäki and Parainen areas compared with their surroundings, they must have been metamorphosed at higher temperatures and pressures than the surrounding areas (Fig. 8). The pressures given by cordierite reaction coronas and reactant garnet rims are 2.3-3.4 kbar at Vellua and 3.1$4.7 \mathrm{kbar}$ elsewhere, THERMOCALC giving slightly higher pressures than GEOPATH.

Fig. 13 shows a pseudosection for the assemblage grt-crd-bt-sil-kfs-qtz, calculated by the THERMOCALC using a whole rock composition, published by Hölttä (1986), from a sillimanitebearing garnet granulite in the Mynämäki area: $\mathrm{SiO}_{2} 57.45 \mathrm{wt} \%, \mathrm{Al}_{2} \mathrm{O}_{3} 20.01 \mathrm{wt} \%, \mathrm{FeO}_{\text {tot }} 9.25$ wt $\%, \mathrm{MgO} 3.51 \mathrm{wt} \%$ and $\mathrm{K}_{2} \mathrm{O} 4.81 \mathrm{wt} \%$. This composition is close to that of metapelitic rocks in the Vellua region (Hietanen 1943). Higher 
whole rock $\mathrm{Mg}$ content and water activity would move the pseudosection to higher temperature and pressure. Fig. 13 shows that with these whole rock compositions at or above about $3.6 \mathrm{kbar}$ pressures, the reaction $\mathrm{bt}+\mathrm{sil}+\mathrm{qtz}=\mathrm{grt}+\mathrm{kfs}+\mathrm{V}$ starts at $620-630^{\circ} \mathrm{C}$. The Fe-rich biotite inclusions in $\mathrm{K}-$ feldspars in granulites and adjacent areas can be explained as representing the early stages of this reaction, the ferromagnesian phases becoming more magnesian with increasing temperature, but the K-feldspar surrounding the biotite inclusions preventing the exchange with other matrix minerals. The Mg numbers of the biotite inclusions in $\mathrm{K}$-feldspars in higher grade zones do not differ much from those in the Vellua metapelites. Both garnet and cordierite are more magnesian in the highest grade granulites than in their surroundings, a feature that indicates that the granulites clearly represent crystallization at higher temperatures and pressures.

Cordierite was partly produced through the univariant reaction (4), after which garnet also started to produce cordierite in reactions (5) and (7) with increasing temperature and/or decreasing pressure. On the basis of reaction textures and mineral compositions, the most probable PT path is clockwise with either near-isobaric heating or heating with compression first and, after that, cooling with decompression, down to the andalusite and muscovite fields. No evidence (e.g. calcic cores in garnets) was found for an early high-pressure stage, but the rare reaction where cordierite was altered to garnet (Fig. 9h) may be an evidence for compression during heating.

In the lowest grade rocks in the area, north of the Vehmaa rapakivi granite, the crd-bt-sil-kfs-qtz assemblage produced by the reaction (3) can be explained by either increasing temperature or decreasing pressure. The reaction (1b), $\mathrm{ms}+\mathrm{crd}+$ $\mathrm{qtz}=\mathrm{bt}+\mathrm{sil}+\mathrm{kfs}+\mathrm{H}_{2} \mathrm{O}$ takes place, according to THERMOCALC, in these compositions in a very narrow PT interval (Fig. 13) with increasing temperature. It is therefore more probable that kfsbt-sil assemblages were produced by the divariant reaction $(1 \mathrm{a}) \mathrm{bt}+\mathrm{sil}+\mathrm{qtz}=\mathrm{crd}+\mathrm{ms}+\mathrm{V}$ which, having a dP/dT slope, produces muscovite and cordierite with decreasing $\mathrm{P}$ and $\mathrm{T}$ or biotite and sillimanite either with isobaric cooling or with increasing $\mathrm{P}$ and $\mathrm{T}$. This reaction is strongly dependent on water activity. In Fig. 13 the reaction is placed at pressures under $2 \mathrm{kbar}$, but if the water activity increases to 0.7 , for example, the reaction (1b) moves to higher pressure and temperature, ending at the univariant reaction curve (1a) at $615^{\circ} \mathrm{C}$ and $3 \mathrm{kbar}$. The reaction (1) in any case takes place in the sillimanite field which according to Fig. 13 is close to the temperature maximum of the crd-bt-sil-kfs zone.

\section{RELATIONSHIP BETWEEN MINERAL GROWTH AND DEFORMATION}

In order to establish the sequence of metamorphic mineral growth in metapelitic rocks, samples representing different deformation phases were collected. Methods used to study the timing of mineral growth and, in particular, porphyroblast growth, are described in Bell and Rubenach (1983), Vernon (1989) and Passchier and Trouw (1996).

Biotite crystallized throughout the deformation history, being syntectonic to $D_{1}-D_{3}$ deformations and parallel to $S_{1}, S_{2}$ and $S_{3}$ foliations. Where biotite occurs as a retrograde alteration product after cordierite, it is randomly oriented representing a static metamorphism after $\mathrm{D}_{3}$. In $\mathrm{D}_{4}$ fault zones, syn- to post-tectonic biotite porphyroblasts are parallel to or randomly overgrow the $\mathrm{D}_{4}$ mylonitic foliation.

Sillimanite occurs in the highest grade granulites only as inclusions in cordierite and garnet and its relationship to early deformation is difficult to establish, but in sillimanite-rich rocks in the Vellua and Korppoo areas, at least two or, probably, three sillimanite generations can be found. Fibrolitic sillimanite overgrows the bedding-parallel $\mathrm{S}_{1}$ biotite and is folded by $\mathrm{F}_{2}$, suggesting late $\mathrm{D}_{1}$ or early $\mathrm{D}_{2}$ growth. Fibrolite further crosscuts the earlier generation and grows in axial planes of $F_{2}$ folds (Fig. 14a). All these sillimanites are folded by $F_{3}$. Some fibrolite grows even along $S_{3}$, but it is unclear whether it represents a new sillimanite generation or reoriented earlier sillimanite. 
Prismatic coarse-grained sillimanite is a later phase which crosscuts fibrolite and $\mathrm{F}_{3}$ folding. Prismatic sillimanite occurs especially in the Korppoo area, but can also be found locally in the Vellua area (Fig. 14b). Late, randomly oriented, small sillimanite needles occurring together with biotite are retrograde alteration products of cordierite (back-reaction 4) in granulites and in areas surrounding granulites.

$K$-feldspar overgrows the $\mathrm{S}_{1}$ biotite foliation which is preserved as straight inclusion trails (Fig. 14c) indicating that $\mathrm{K}$-feldspar was a late $\mathrm{D}_{1}$ to early $\mathrm{D}_{2}$ mineral. In the Mynämäki and Parainen granulites, the high-temperature metamorphism with partial melting has commonly destroyed the inclusion trail textures. Later K-feldspars crystallized from melt (Figs. 9f and 9g).

Cordierite overgrows both folded $\mathrm{S}_{1}$ and straight $\mathrm{S}_{2}$, including the sillimanites. Cordierite is elongated along $\mathrm{S}_{2}$, and $\mathrm{S}_{2}$ does not wrap around cordierite (Fig. 14d). This first generation cordierite is therefore a late to post $\mathrm{D}_{2}$ mineral because it is deformed by $\mathrm{F}_{3}$. Later euhedral cordierite is produced by the melting reaction (4), occurring in leucosomes that are in $\mathrm{F}_{3}$ axial planes and cut the $\mathrm{F}_{3}$ folds. The cordierite that is a breakdown product of garnet (Figs. 9c and 9d) is interpreted as the latest cordierite generation.

Early garnet occurs in all metamorphic zones as elongated porphyroblasts along and overgrowing $\mathrm{S}_{2}: \mathrm{S}_{\mathrm{i}}$ (internal) and $\mathrm{S}_{\mathrm{e}}$ (external) are continuous and $S_{2}$ does not deflect around the porphyroblasts. $S_{1}$ is locally visible as inclusion trails (Fig. $14 \mathrm{e}$ ), but in those cases $S_{1}$ also occurs outside the porphyroblasts. Early garnet was deformed by $\mathrm{F}_{3}$ (Fig. 14f), so this garnet must be a late to post $\mathrm{D}_{2}$ mineral, but earlier than the main phase of $\mathrm{F}_{3}$. Hence, the early garnet and the early cordierite are coeval. A second generation of garnet occurs as euhedral minerals in leucosomes which, in places, cut $\mathrm{F}_{3}$ folds, being produced by the melting reaction (4) (Figs. 7b and $14 \mathrm{~g}$ ). Garnets were also crystallized syntectonically within the $\mathrm{D}_{3}$ shear zones (Fig. 4f).

Andalusite occurs as a randomly oriented, posttectonic, retrograde phase after cordierite.

Muscovite is restricted to the crd-kfs zone in the northern part of the study area. It is found both as aligned along $\mathrm{S}_{2}$ and as a randomly oriented retrograde mineral that overgrows $\mathrm{D}_{3}$ structures, produced by reactions (1) and (2). It also occurs syn- to post-tectonically in $\mathrm{D}_{4}$ shear zones together with biotite. The mode of occurrence suggests that there may be several muscovite generations.

\section{RELATIONSHIP BETWEEN DEFORMATION AND GRANITOIDS}

\section{Early orogenic granitoids}

Early orogenic I-type granitoids are commonly either foliated or gneissic tonalites containing mafic enclaves or schlieren, depending on the intensity of deformation. Subordinate trondhjemites, granodiorites, diorites and gabbros belong to the same early orogenic group. They have all been dated at 1.89-1.87 Ga (U-Pb zircon ages by Patchett \& Kouvo 1986, Suominen 1991 and van Duin 1992), except two trondhjemite samples from Kalanti, south of Uusikaupunki, that yielded an age in excess of $1.90 \mathrm{Ga}$ (Patchett \& Kouvo 1986). The early orogenic tonalites occur mainly as concordant sheet-like intrusions within the $\mathrm{D}_{2}$ deformed gneisses. The tonalites show $\mathrm{S}_{2}$ foliation at their margins, but in the innermost parts of the largest intrusions the degree of foliation is weak or in places absent. The relationship between these tonalites and $\mathrm{D}_{2}$ deformation is best determined by their contact relationship to the $\mathrm{F}_{2}$ folds. During folding, the tonalitic magma intruded the folds filling the fold hinges and as it continued to intrude, cut the folds along axial planes. Continued deformation foliated the tonalites (Figs. 6a and 6b). All these observations demonstrate that the tonalites are syntectonic with respect to $\mathrm{D}_{2}$ deformation, regardless whether the tonalites are from the northern or from the central part of the study area. Hence, $D_{2}$ deformation continued until at least $1869 \pm 5 \mathrm{Ma}$ which is the age of the tonalite at Masku, $15 \mathrm{~km} \mathrm{~N}$ of Turku. The $\mathrm{D}_{2}$ fabric in tonalites is in turn deformed by $\mathrm{F}_{3}$ (Fig. 6c).

The enderbites give zircon ages of ca. 1.86-1.82 Ga, with very large uncertainties (Suominen 1991, 
van Duin 1992). The ages between the early and late orogenic stage led Suominen (1991) to call these rocks intraorogenic rocks. The enderbites are, however, deformed exactly in the same way as the orthopyroxene-free early orogenic tonalites (Fig. 6d), which suggests that these ages are metamorphic rather than crystallization ages. This interpretation is strongly supported by a $1.88 \mathrm{Ga}$ zircon population found in one of the intrusions (Suominen 1991). Mäkitie (1993) described similar pyroxene-bearing tonalites from Sipoo, east of Helsinki, and concluded that pyroxene is a metamorphic mineral and that the tonalites are synkinematic, i.e. they correlate with the early orogenic granitoids of the present study.

\section{Late orogenic granitoids}

Late orogenic granites dated at 1.84-1.83 Ga (Huhma 1986, Patchett \& Kouvo 1986, Suominen 1991) are S-type, coarse-grained granites, often called microcline granites. They occur as large intrusions, like the porphyritic Perniö and Hanko granites (Huhma 1986, Ehlers et al. 1993a), as veins, and as garnet- and cordierite-bearing leucosomes in metasedimentary and older igneous rocks. The zircon and monazite $\mathrm{U}-\mathrm{Pb}$ ages of leucosomes in the eastern part of the LSGM zone (1.850-1.810 Ga, Korsman et al. 1984) indicate that leucosomes in migmatites are temporally indistinguishable from the large granite intrusions, therefore suggesting a common origin.

Stromatic leucosome veins were already produced during the $\mathrm{D}_{2}$ (Fig. 6e), but the amount of leucosome greatly increased during $\mathrm{D}_{3}$. In regions with lower abundances of leucosome, small melt patches with garnet occur in the axial planes of $\mathrm{F}_{3}$ folds (Fig. $6 \mathrm{f}$ ). In areas with high abundances of melt, the melt simultaneously filled hinges of $\mathrm{F}_{3}$ folds and intruded along $\mathrm{F}_{3}$ axial planes forming boudins (Figs. 7a, 7b and 4c). The latest leucosome phases postdate the $\mathrm{F}_{3}$ folding, brecciating the $\mathrm{F}_{3}$ hinge areas (Fig. 7c). The abundance of late orogenic granites is high in the southern part of the Turku domain. Field relationships indicate that leucosome formation started with small veins and melt patches, and ended with the for- mation of large granite areas. Ehlers et al. (1993a) argue that the granites were intruded along reactivated pre-existing thrust zones. According to our observations, however, granite magma/melt transfer and accumulation utilized all existing structures such as the $F_{3}$ fold hinges, $F_{3}$ axial planes, boudin necks, the $\mathrm{D}_{3}$ shear zones and the earlier $S_{2}$ foliation planes in areas where $D_{3}$ is weak or strongly overturned. This mode of granite magma migration resembles the model of Collins and Sawyer (1996) who described the pervasive magma transfer during non-coaxial compressional deformation. $\mathrm{D}_{3}$ shear zones filled with granite probably acted as channels for the melt movement to higher structural levels as described by d'Lemos et al. (1992).

\section{Postorogenic and anorogenic granitoids}

Postorogenic intrusions, dated at $1815-1770 \mathrm{Ma}$ (Patchett \& Kouvo 1986, Korsman et al. 1984, Suominen 1991, Vaasjoki 1995, 1996), are spatially part of the LSGM zone. They are not voluminous, but are randomly exposed throughout the LSGM zone. They normally are undeformed granitoids which cut the $D_{1}-D_{3}$ structures and the late orogenic granites but, in places, are deformed by shearing (Sederholm 1934, Branigan 1987). The relationship of the postorogenic intrusions to deformation is unclear. In the Aland archipelago (Fig. 2), 1.79-1.80 Ga intrusions follow the NNE trending $\mathrm{D}_{4}$ shear zones and are locally sheared

Fig. 14. Relationships between mineral growth and deformation phases. a) Early sillimanite is folded by $F_{2}$ (fold hinge is seen in the right part of the figure) and younger sillimanite grows along the axial plane. Scale bar $1 \mathrm{~mm}$ long. Vellua, map sheet 1131 10, $x=6741100$, $y=1533200$. b) Two sillimanite generations; the earlier fibrolite is folded and crenulated by open $F_{3}$ and later prismatic sillimanite partly overgrows $F_{3}$ folds. Scale bar $1 \mathrm{~mm}$ long. Korppoo, map sheet 1032 12, $x=6671100, y=1530400$. c) $K$-feldspar has straight $S E$ $N W S_{1}$ biotite and quartz inclusion trails nearly perpendicular to the $\mathrm{N}-\mathrm{S} \mathrm{S}_{2}$ in the matrix. Scale bar $1 \mathrm{~mm}$ long. Yläne, map sheet 1133 04, $x=6740350, y=1558900$. $d$ ) Cordierite (partly in extinction) overgrows $S_{1}$ folded by $F_{2}$. Field of view $4 \mathrm{~mm}$. Raisio, map sheet 104407 , 

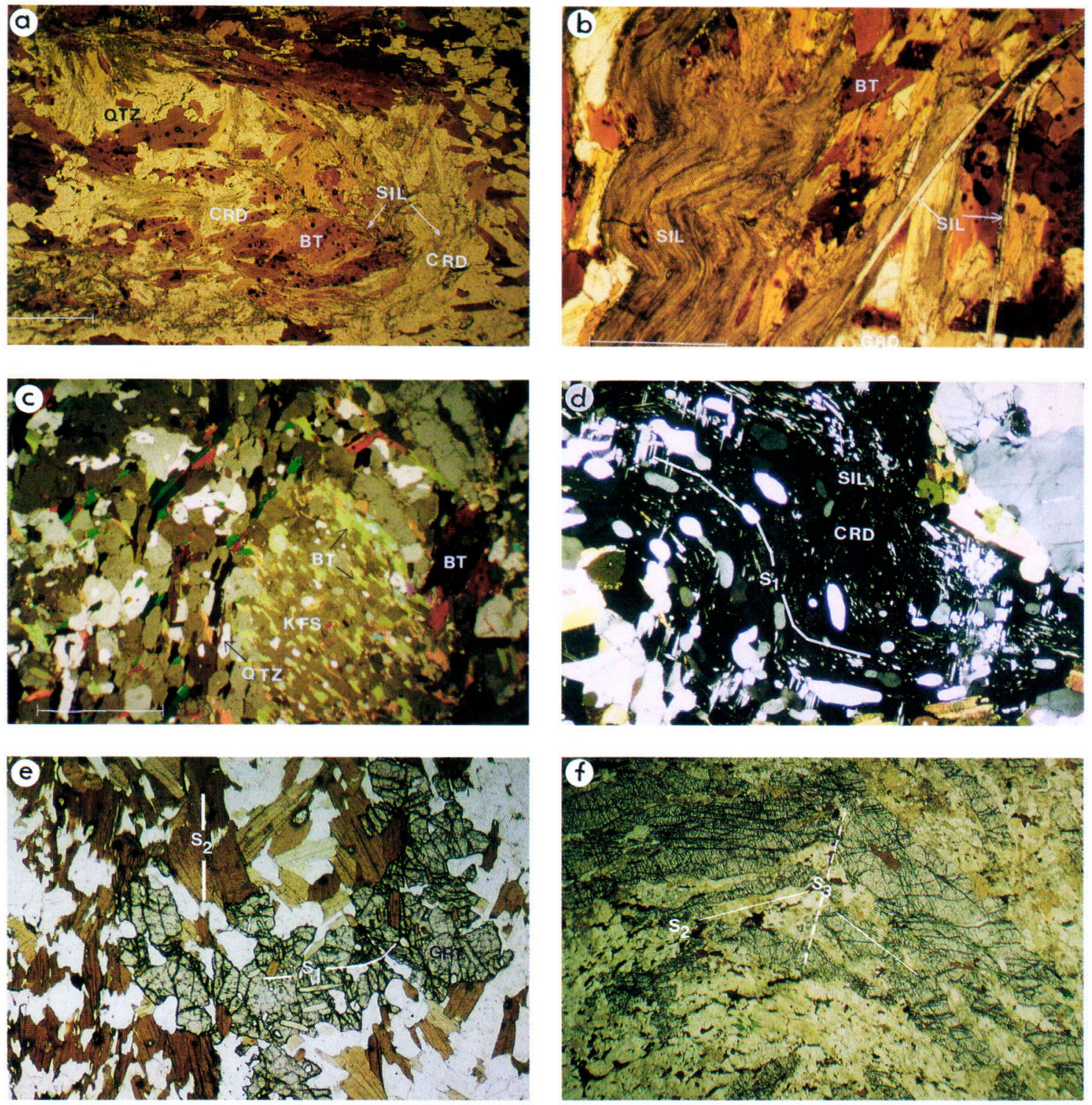

$x=6710750, y=1566850$. e) Garnet overgrows both $S_{1}$ (inclusions in the centre of the garnet) and $S_{2}$ main matrix foliation (on edges of the garnet). Field of view $2 \mathrm{~mm}$. Raisio, map sheet 1044 07, $x=6710750$, $y=1566850 . f)$ Elongated garnets parallel to $S_{2}(E-W)$ are deformed by $D_{3}(\mathrm{~N}-\mathrm{S})$. Field of view $10 \mathrm{~mm}$ wide. From the exposure in Fig. 7c. Map sheet 1042 12, $x=6738600, y=1533300 . \mathrm{g}$ ) Early generation of garnet parallel to $S_{2}$ (left) is deformed by $D_{3}$. Younger euhedral generation of garnet (top right) is in a melt patch. Field of view $2 \mathrm{~mm}$ wide. Rusko, map sheet 1044 07, $x=6712900, y=1567550$.

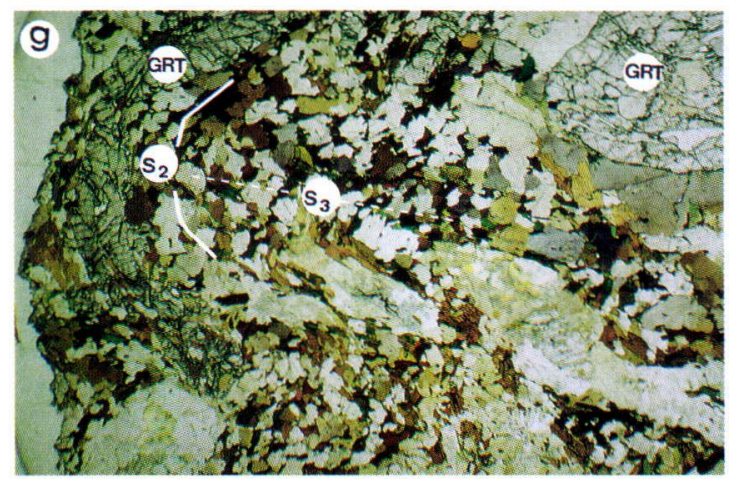


themselves, suggesting that shearing was coeval with intrusions (Branigan 1987, Ehlers et al. 1993b). In the Turku domain, there are several bimodal dioritic and granitic intrusions. One of them, Urusvuori in the city of Turku, is dated at 1815 Ma (Väisänen et al. submitted). Intrusions of this age have been considered to belong to the same postorogenic group as the slightly younger and more common varieties (Vaasjoki 1995). However, the granite at Urusvuori is a garnet-bearing variety that more closely resembles the late orogenic granites than the younger postorogenic granitoids in SW Finland (Hubbard \& Branigan 1987). The Urusvuori diorite exhibits a weak preferred orientation, which we interpret as a magmatic fabric. The Urusvuori granite forms dykes into diorite, and enclaves and patches of granite occur in diorite (Figs. 7d and 7e). These features indicate coeval mafic and felsic magmatism. These intrusions are not as clearly associated with the $\mathrm{D}_{4}$ shear zones as the postorogenic intrusions in Åland and may instead be tectonically more closely associated with the late orogenic group.

The Laitila, Vehmaa and Åland rapakivi granites, diabase dyke sets and anorthosite intrusions (1.57 Ga, Vaasjoki 1977, Suominen 1991) represent anorogenic magmatism in southwestern Finland. Korja and Heikkinen (1995) suggested that the rapakivi association is related to extension. Their argument was based on listric faults in the lower crust, as interpreted from the seismic reflection profiles (BABEL Working Group 1993). In contrast, Stel et al. (1993) argued that there was no significant extension in southern Finland at that time as they found no significant structural evidence for extension on the present erosion surface. According to Stel et al. (1993) the thinning of the crust was caused by uplift only.

\section{PARTIAL MELTING}

Large areas in the late Svecofennian granitemigmatite belt in southern Finland consist of coarse-grained microcline-rich granites, and an important question is whether the granitic melt was formed in situ, mainly due to biotite dehydra- tion, or whether the system was open, allowing the ingress of melt from deeper units.

Dehydration melting, in which hydrous minerals (micas, amphiboles) break down into waterundersaturated hydrous melts and anhydrous solids, is thought to be the most important crustal melting process. Experimental work has shown that in biotite gneisses and in amphibolites, temperatures of $850{ }^{\circ} \mathrm{C}$ are needed for extensive dehydration melting (e.g. Le Breton \& Thompson 1988, Vielzeuf \& Holloway 1988, Patiño Douce \& Johnston 1991, Patiño Douce \& Beard 1995 and references therein). Geothermometry gives temperatures exceeding $800^{\circ} \mathrm{C}$ only in the Mynämäki and Parainen granulites which also have the largest amount of leucosome, locally up to 70-80 vol.\%. Because the closure temperature of several thermobarometric systems is about $800^{\circ} \mathrm{C}$ (Harley 1989), these temperatures may represent closure during cooling. Field relationships indicate in situ melting in many exposures in the granulite domains and surrounding areas (Figs. 7b and 10). The amount of leucosome correlates well with mineral compositions and preservation of primary structures. Therefore it is evident that a great deal, if not all, of the leucosomes was formed in situ. The melts do not seem to have been expelled from one lithology to another. In road cuts of the Piikkiö-Turku motorway, which goes across the Parainen granulite area, there are mafic, garnetfree interlayers in garnetiferous pelitic granulites. These mafic rocks are biotite rich and have granitic, pink, garnet-free leucosomes, which differ from the garnet- and cordierite-bearing leucosomes of the pelitic granulites. Both rock types are strongly migmatized, but leucosomes do not intrude from one lithology into another which suggests that, at least at this locality, the melts crystallized where they formed.

\section{DISCUSSION}

\section{Structural and metamorphic evolution}

The Svecofennian orogeny was caused by the accretion of island arcs against the Archaean basement. This resulted in a complex and prolonged 
structural evolution which varies in details in time and space in different parts of the Svecofennian Orogen. In the Turku area, three main deformation phases can be recognised, $D_{1} / D_{2}, D_{3}$ and $D_{4}$.

\section{$D_{1} / D_{2}$, the early orogenic deformation}

The maximum age for the onset of deformation and metamorphism in SW Finland is the age of the HSB metavolcanic rocks $100 \mathrm{~km}$ NE of Turku, $1888 \pm 11$ Ma (Vaasjoki 1994). The earliest stage of metamorphism and deformation is indicated by the bedding-parallel biotite+sillimanite foliation folded around the recumbent $\mathrm{F}_{2}$ folds, which means that these rocks were at least in mediumgrade metamorphic conditions already during $\mathrm{D}_{1}$. The $\mathrm{F}_{2}$ folds are approximately coeval with the early orogenic 1.89-1.87 Ga granitoids, therefore, the ages of the granitoids give the age of the deformation as well. The flat-lying nature of the $\mathrm{D}_{2}$ deformed gneisses and granitoids indicates thrust tectonics related to the collision and thickening of the crust. Extension leading to crustal thinning is not a probable cause for subhorizontal foliations and folds because of the overall collisional nature of the 1.89-1.88 Ga tectonics in the Svecofennides (e.g. Lahtinen 1994) and due to the lack of evidence for an early high-pressure event (i.e. pre$\mathrm{D}_{2}$ ) that would have experienced decompression during $\mathrm{D}_{2}$.

In Kemiö, $50 \mathrm{~km} \mathrm{SE}$ of Turku (Fig. 2), van Staal and Williams (1983) described recumbent $\mathrm{F}_{2}$ folds and horizontal $\mathrm{S}_{2}$ that deformed both paraand orthogneisses, and which were later refolded by younger upright folds. They interpreted the horizontal structures as thrust sheets where higher pressure rocks were thrusted over the lower pressure ones. The structural succession of van Staal and Williams (1983) closely resembles that described above for the Turku area and also the one described by Ehlers et al. (1993a) for the archipelago SW of Turku. The $\mathrm{D}_{1}$ phase of Ehlers et al. $(1993 \mathrm{a}, \mathrm{b})$ created the early thrusting related recumbent folds that also deformed the syntectonic $1.89-1.88 \mathrm{Ga}$ granitoids. The $\mathrm{D}_{1}$ also slightly deformed the $1.87 \mathrm{Ga}$ granodiorites. The $\mathrm{D}_{1}$ of Ehlers et al. (1993a, b) evidently correlates with the
$\mathrm{D}_{2}$ of this study and the $\mathrm{F}_{2}$ of van Staal \& Williams (1983).

Although thrust tectonics easily explains the recumbent structures, no major thrust zones have been identified. Some 100-200 km north and northeast of Turku, in the Loimaa (Nironen 1999), Pori (Pietikäinen 1994) and Tampere-Vammala (Nironen 1989b, Kilpeläinen 1998) areas, deformation created upright structures compared to contemporaneous recumbent structures in the Turku area. These differences in structural style can be explained by the large-scale flat-and-ramp structures typical of fold and thrust belts (e.g. Ramsay \& Huber 1987). The tectonic translation direction during the 1.89-1.87 Ga tectonism is not understood in detail in southernmost Finland, because later deformation during high heat flow obscured the details of the earlier structures. Some recumbent $\mathrm{F}_{2}$ folds in the Turku area are northward facing and, if those folds are representative of the kinematics of the $\mathrm{D}_{2}$ deformation, they are in good agreement with other observations in the Finnish Svecofennides. According to Ehlers et al. (1993a), the early $D_{1}$ folds in the Turku archipelago are overturned towards the west or northwest. Although the fold axis and facing alone do not reveal the tectonic translation direction, they do not support a movement from north to south. Further north, in the Tampere area, Nironen (1989b) studied the kinematics of shear zones and reported a south side up movement along the shear zone between the Tampere Schist Belt and the Vammala Migmatite Belt to the south. Lahtinen (1994) proposed a suture zone between Tampere and Häme Schist Belts, being presently approximately within the Vammala Migmatite Belt, with the southern plate overriding the northern one during collision. All these local interpretations of tectonic translation directions point to approximately northerly directed arc accretion in southern Finland. This is in agreement with the structural analysis by Ward (1987), as he concluded that thrusting was northward in eastern Finland along the Archaean border.

In southernmost Finland, the compressional deformation outlasted the $1.87 \mathrm{Ga}$ magmatism, as described in this study and by Ehlers et al. (1993a) 
and Nironen (1999). However, in the southern part of the Central Finland Granitoid Complex, the contemporaneous magmatism is extensional in geochemical character and resembles rapakivi granites rather than collisional 1.89-1.88 Ga granitoids (Rämö \& Nironen 1996). Contemporaneous compression and extension has been detected in younger orogens (e.g. Hodges \& Walker 1992). The same analogue could be applied to the Svecofennian orogen as well and, in particular, to southernmost Finland. According to this model, compressional tectonism prevailed in the LSGM zone while the Tampere area to the north was already in the extensional stage.

On the basis of the relationships between mineral growth and deformation phases, the upper amphibolite facies assemblage garnet-cordieritesillimanite-K-feldspar (melt) was stable during $\mathrm{D}_{2}$. This is in agreement with Hopgood et al. (1983) who described 1890-1870 Ma migmatites in southern Finland. The highest grade granulite facies metamorphism with extensive anatectic melting of the crust was, however, reached ca. 30 million years later, during the late orogenic stage.

\section{$D_{3}$, the late orogenic deformation}

In the LSGM zone, the 1.89-1.87 Ga collision was followed by intensive NW-SE shortening and continued thickening of the crust. Early subhorizontal structures were refolded by the regional, open to tight folds which are upright or slightly overturned towards the NW. Regional folds of this kind of geometry are common throughout the coastal area of southern Finland and have been described as $D_{1}$ by Veenhof and Stel (1991), $F_{2}$ by Schreurs and Westra (1986), Bleeker and Westra (1987), Ehlers et al. (1993a) and Lindroos and Ehlers (1994), $F_{3}$ by Selonen et al. (1996) and $\mathrm{F}_{4}$ by van Staal and Williams (1983). Descriptions of this folding in these papers correlate well with the $\mathrm{D}_{3}$ deformation described in the present study. In the Turku area, $\mathrm{D}_{3}$ created the most prominent folds and is responsible for the major lithological and structural patterns seen on geological and geophysical maps. According to the above structural analysis, the age of this deformation is close to the age of the late orogenic granites, i.e. around 1.84$1.83 \mathrm{Ga}$ (cf. Ehlers et al. 1993a), while Lindroos et al. (1996) argue that the same deformation continued at least until the emplacement of the 1805 Ma pegmatites.

On the basis of the fold style of the upright and $\mathrm{N}$ or NW overturned folds, the most likely tectonic setting is a compressional late orogenic crustal shortening stage that culminated in granulite facies metamorphism and melting of the crust. Detailed kinematics of this late orogenic deformation are still ambiguous. The asymmetry of the $F_{3}$ folds described in this study and in other descriptions of the LSGM zone (van Staal \& Williams 1983), structural data in Bleeker and Westra (1987) and Veenhof and Stel (1991) point to N or NW directed shortening, i.e. orthogonal to the LSGM zone (Fig. 1), and approximately in the same direction as during the earlier stage of the Svecofennian orogeny. Ehlers et al. (1993a) suggested that the LSGM is a dextral transpressive intracratonic zone, i.e., the collisional translation direction is oblique to the strike of the zone. Paradoxically, the direction of the regional transpressional force they report is orthogonal to the LSGM zone. If the dextral transpression model is valid, the movement direction during the Svecofennian orogeny must have changed from an early, northerly direction to a late, westerly direction. Oblique collision is supported by the E and SE plunging lineations in the gently dipping E-W trending $\mathrm{D}_{3}$ shear zone north of the Vehmaa rapakivi intrusion (Fig. 3). Nironen (1999) describes N-S trending, intense, younger than $1.87 \mathrm{Ga}$ folding in the Loimaa area, which strongly points to a late stage E-W compression. More data on the kinematics of the shear zones bounding the folded areas are needed to reveal the overall tectonic regime of the LSGM zone. Presently, the model of dextral transpression seems most likely. This model is also applied to the Swedish part of the Svecofennides, the inferred western continuation of the LSGM zone in Sweden, by Sjöström and Bergman (1996) and Stephens and Wahlgren (1996) who describe fold and shear zone geometries that resemble those described here. The metamorphic evolution is also similar in the Stockholm area in Sweden (Anders- 
son 1997), and the two areas are therefore tentatively correlated.

The highest grade granulite facies conditions in the Turku area were reached during the late orogenic $\left(D_{3}\right)$ stage when supracrustal rocks were melted to form S-type late orogenic granites. They were formed in the highest pressure conditions (6 kbar) reached in this part of the Svecofennides. Textures that may indicate decompression, especially alteration of garnet into cordierite, are interpreted as late or post- $\mathrm{D}_{3}$ textures. Therefore, the late orogenic metamorphism and associated granites are part of the collisional stage of the Svecofennian orogeny. The cooling path presented in Fig. 13 was caused by exhumation that followed soon after or during the late $\mathrm{D}_{3}$ while the rocks were still hot enough to be reactive. Crustal thickening simultaneous with thinning of the mantle lithosphere is a possible model to explain this kind of pressure-temperature-deformation path (Sandiford \& Powell 1991), as suggested already by van Duin and Nieman (1993) for the Turku area.

\section{$D_{4}$, the postorogenic deformation}

The tectonic significance and the age of the $D_{4}$ postmetamorphic faults is uncertain. On the basis of overprinting criteria, they clearly are later than the late orogenic granites. In the Alland archipelago, to the W of Turku, Branigan (1987) and Ehlers et al. (1993b) tentatively correlate them with the postorogenic intrusions, whereas $40 \mathrm{~km} \mathrm{SW}$ of Helsinki the $1640 \mathrm{Ma}$ Obbnäs rapakivi granite is affected by shearing. The faulting activity is obviously not coeval throughout southern Finland or there are faults of different ages.

If the E-side down movement, as determined from the Mynälahti and Paimio faults, is consistent for all similar faults, it demonstrates a fundamental change in the orogeny from a constrictional to extensional setting and could demonstrate the collapse of the Svecofennian orogen (Korja \& Heikkinen 1995). These observations are supported by the study of Pietikäinen (1994), as he describes extensional late shear zones cutting the pegmatite granites in the Pori area, $200 \mathrm{~km}$ to the $\mathrm{N}$ of Turku.

\section{CONCLUSIONS}

From the present study, the following conclusions can be drawn:

1. In the Turku area, the early orogenic $1.89-1.87$ Ga tonalites were intruded as sills into subhorizontal $\mathrm{D}_{2}$ structures during crustal thickening. Metamorphism reached upper amphibolite facies conditions during $\mathrm{D}_{2}$ with garnet-cordierite-sillimanite-K-feldspar-quartz mineral parageneses and the onset of migmatization in metapelites.

2. Based on structural analysis, the enderbites are early orogenic granitoids. Their conventional $1.86-1.82 \mathrm{Ga} \mathrm{U}-\mathrm{Pb}$ zircon ages are evidently metamorphic.

3. The late orogenic $\mathrm{D}_{3}$ deformation took place during a crustal shortening period that created both upright $\mathrm{F}_{3}$ folds and thrusts in different places. The direction of shortening was oblique to the trend of the orogen in southern Finland, i.e. transpressional.

4. The late orogenic crustal shortening was simultaneous with granulite facies high-temperature/ low-pressure metamorphism and the formation of large amounts of crustal melts which crystallized at $1.84-1.83 \mathrm{Ga}$ as late orogenic granites.

ACKNOWLEDGEMENTS. The authors gratefully acknowledge the reviews of Pasi Eilu, Yrjö Kähkönen, Leo Kriegsman and Mikko Nironen, which greatly helped to improve the manuscript. Special thanks are due to Kalevi Korsman, Jukka Jokela and Amanda Voase for stimulating discussions during the various stages of this work. Timo Kilpeläinen helped with computer graphics. MV was funded by the Ministry of Education through the Lithosphere Graduate School and he also appreciates funding from the Geological Survey of Finland. The English was revised by Hugh O'Brien. 


\section{REFERENCES}

Andersson, U.B. 1997. The late Svecofennian, high-grade contact and regional metamorphism in southwestern Bergslagen (central southern Sweden). Final report 970519, SGU-Report 03-819/93. 36 p. (unpublished).

BABEL Working Group 1993. Integrated seismic studies of the Baltic Shield using data in the Gulf of Bothnia region. Geophysical Journal International 112, 305-324.

Bell, T.H. 1985. Deformation partitioning and porphyroblast rotation in metamorphic rocks: a radical reinterpretation. Journal of Metamorphic Geology 3, 109-118.

Bell, T.H. \& Rubenach, M.J. 1983. Sequential porphyroblast growth and crenulation cleavage development during progressive deformation. Tectonophysics 92, 171194.

Bleeker, W. \& Westra, L. 1987. The evolution of the Mustio gneiss dome, Svecofennides of SW Finland. Precambrian Research 36, 227-240.

Branigan, N.P. 1987. The role of shearing in the Proterozoic development of the Aland archipelago, S.W. Finland. Bulletin of the Geological Society of Finland 59, 117-128.

Carrington, D.P. \& Harley, S.L. 1995. Partial melting and phase relations in high-grade metapelites: an experimental petrogenetic grid in the KFMASH system. Contributions to Mineralogy and Petrology 120, 270-291.

Colley, H. \& Westra, L. 1987. The volcano-tectonic setting and mineralisation of the early Proterozoic KemiöOrijärvi-Lohja belt, SW Finland. In: Pharaoh, T.C., Beckinsale, R.D. \& Rickard, D. (eds.) Geochemistry and Mineralisations of Proterozoic Volcanic Suites. Geological Society Special Publications 33, 95-107.

Collins, W.J. \& Sawyer, E.W. 1996. Pervasive granitoid magma transfer through the lower-middle crust during non-coaxial compressional deformation. Journal of Metamorphic Geology 14, 565-579.

D'Lemos, R.S., Brown, M. \& Strachan, R.A. 1992. Granite magma generation, ascent and emplacement within a transpressional orogen. Journal of the Geological Society $149,487-490$.

Dietvorst, E.J.L. 1982. Prograde metamorphic zoning in amphibolite facies pelitic gneisses from Kemiö, southwest Finland. Geologische Rundschau 71, 245-262.

Ehlers, C., Lindroos, A. \& Selonen, O. 1993a. The late Svecofennian granite-migmatite zone of southern Finland - a belt of transpressive deformation and granite emplacement. Precambrian Research 64, 295-309.

Ehlers, C., Lindroos, A., Vaasjoki, M. \& Selonen, O. 1993b. A tentative chronology of the early stages of intrusion, deformation and metamorphism in the migmatite zone of southern Finland. In: Symposium on "The Svecofennian Domain", geological/geophysical aspects of the continental crust and Annual Meeting of IGCP 275 in Turku, Finland, August 23-25, 1993. Abstracts, p. 19.

Eskola, P. 1914. On the petrology of the Orijärvi region in southwestern Finland. Bulletin de la Commission géologique de Finlande 40. 279 p.

Gaál, G. \& Gorbatschev, R. 1987. An outline of the Precambrian evolution of the Baltic Shield. Precambrian Research 35, 15-52.

Gerya, T.V. \& Perchuk, L.L. 1992. GEOPATH - a thermodynamic database for geothermobarometry and related calculations with the IBM PC AT/XT computer. 29th International Geological Congress, Kyoto, V. 2., p. 1026.

Haapala, I. \& Rämö, O.T. 1992. Tectonic setting and the origin of the Proterozoic rapakivi granites of southeastern Fennoscandia. Transactions of the Royal Society of Edinburgh: Earth Sciences 83, 165-171.

Hakkarainen, G. 1994. Geology and geochemistry of the Hämeenlinna-Somero Volcanic Belt, southwestern Finland: a Paleoproterozoic island arc. Geological Survey of Finland, Special Paper 19, 85-100.

Harley, S.L. 1989. The origin of the granulites: a metamorphic perspective. Geological Magazine 126, 215-247.

Härme, M. 1960. General Geological Map of Finland. PreQuaternary Rocks, Sheet B1, Turku. 1:400 000.

Heeremans, M., Stel, H., van der Beek, P. \& Lankreijer, A. 1996. Tectono-magmatic control on vertical dip slip basement faulting: An example from the Fennoscandian Shield. Terra Nova 8, 129-140.

Hietanen, A. 1943. Über das Grundgebirge des Kalantigebietes im südwestlichen Finnland. Bulletin de la Commission géologique de Finlande 130.106 p.

Hietanen, A. 1947. Archaean geology of the Turku district in southwestern Finland. Bulletin of Geological Society of America 58, 1019-1084.

Hietanen, A. 1975. Generation of potassium-poor magmas in the northern Sierra Nevada and the Svecofennian in Finland. Journal of Research, U.S. Geological Survey, 3, 631-645.

Hobbs, B.E., Means, W.D. \& Williams, P.F. 1976. An Outline of Structural Geology. New York: John Wiley \& Sons. 571 p.

Hodges, K.V. \& Walker, J.D. 1992. Extension in the Cretaceous Sevier orogen, North American Cordillera. Geological Society of America Bulletin 104, 560-569.

Holland, T.J.B. \& Powell, R., 1990. An enlarged and updated internally consistent thermodynamic dataset with uncertainties and corrections: the system $\mathrm{K}_{2} \mathrm{O}-\mathrm{Na}_{2} \mathrm{O}-$ $\mathrm{CaO}-\mathrm{MgO}-\mathrm{MnO}-\mathrm{FeO}-\mathrm{Fe}_{2} \mathrm{O}_{3}-\mathrm{Al}_{2} \mathrm{O}_{3}-\mathrm{TiO}_{2}-\mathrm{SiO}_{2}-\mathrm{C}-\mathrm{H}_{2}-\mathrm{O}_{2}$. Journal of Metamorphic Geology 8, 89-124.

Hölttä, P. 1986. Observations of the metamorphic reactions and PT conditions in the Turku granulite area. Geological Survey of Finland, Bulletin 339, 43-58.

Hopgood, A.M., Bowes, D.R., Kouvo, O. \& Halliday, A.D. 1983. U-Pb and Rb-Sr isotopic study of polyphase deformed migmatites in the Svecokarelides, southern Finland. In: Atherton, M.P. \& Gribble, C.D. (eds.) Migmatites, Melting and Metamorphism. Nantwich: Shiva, $80-92$

Hubbard, F. \& Branigan, N. 1987. Late Svecofennian magmatism and tectonism, Åland, southwest Finland. Precambrian Research 35, 241-256.

Huhma, H. 1986. Sm-Nd, U-Pb and $\mathrm{Pb}-\mathrm{Pb}$ isotopic evi- 
dence for the origin of the Early Proterozoic Svecokarelian crust in Finland. Geological Survey of Finland, Bulletin 337.48 p.

Kähkönen, Y. 1996. Stratigraphy and evolution of the Paleoproterozoic supracrustal rocks in the Tampere area, southern Finland: a preliminary review. Geological Survey of Finland, Report of Investigations 136, 9-12.

Kähkönen, Y., Huhma, H. \& Aro, K. 1989. U-Pb zircon ages and $\mathrm{Rb}-\mathrm{Sr}$ whole-rock isotope studies of early Proterozoic volcanic and plutonic rocks near Tampere, southern Finland. Precambrian Research 45, 27-43.

Kilpeläinen, T. 1998. Evolution and 3D modelling of the structural and metamorphic patterns of the Palaeoproterozoic crust in the Tampere-Vammala area, southern Finland. Geological Survey of Finland, Bulletin 397. $124 \mathrm{p}$.

Kilpeläinen, T., Korikovsky, S., Korsman, K. \& Nironen, M. 1994. Tectono-metamorphic evolution in the Tampere-Vammala area. Geological Survey of Finland, Guide 37, 27-34.

Kohonen, J. 1995. From continental rifting to collisional crustal shortening - Paleoproterozoic Kaleva metasediments of the Höytiäinen area in North Karelia, Finland. Geological Survey of Finland, Bulletin 380. 79 p.

Koistinen, T.J. 1981. Structural evolution of an early Proterozoic strata-bound $\mathrm{Cu}-\mathrm{Co}-\mathrm{Zn}$ deposit, Outokumpu, Finland. Transactions of the Royal Society of Edinburgh: Earth Sciences 72, 115-158.

Koistinen, T. (ed.) 1994. Precambrian basement of the Gulf of Finland and surrounding area, 1:1 mill. Espoo: Geological Survey of Finland.

Kontinen, A. 1987. An early Proterozoic ophiolite - the Jormua mafic-ultramafic complex, northeastern Finland. Precambrian Research 35, 313-341.

Korja, A. \& Heikkinen, P. 1995. Proterozoic extensional tectonics of the central Fennoscandian Shield: results from the Baltic and Bothnian Echoes from the Lithosphere experiment. Tectonics 14, 504-517.

Korja, A., Korja, T., Luosto, U. \& Heikkinen, P. 1993. Seismic and geoelectric evidence for collisional and extensional events in the Fennoscandian Shield - implications for Precambrian crustal evolution. Tectonophysics 219, 129-152.

Korja, T., Luosto, U., Korsman, K. \& Pajunen, M. 1994. Geophysical and metamorphic features of Palaeoproterozoic Svecofennian orogeny and Palaeoproterozoic overprinting on Archaean crust. Geological Survey of Finland, Guide 37, 11-20.

Korsman, K., Hölttä, P., Hautala, T. \& Wasenius, P. 1984. Metamorphism as an indicator of evolution and structure of crust in eastern Finland. Geological Survey of Finland, Bulletin 328.40 p.

Korsman, K., Koistinen, T., Kohonen, J., Wennerström, M., Ekdahl, E., Honkamo, M., Idman, H. \& Pekkala, Y. (eds.) 1997. Bedrock map of Finland 1:1000000. Espoo: Geological Survey of Finland.

Kretz, R. 1983. Symbols for rock-forming minerals. American Mineralogist 68, 277-279.
Lahtinen, R. 1994. Crustal evolution of the Svecofennian and Karelian domains during 2.1-1.79 Ga, with special emphasis on the geochemistry and origin of 1.93-1.91 $\mathrm{Ga}$ gneissic tonalites and associated supracrustal rocks in the Rautalampi area, central Finland. Geological Survey of Finland, Bulletin 378. 128 p.

Latvalahti, U. 1979. Cu-Pb-Zn ores in the Aijala-Orijärvi area, Southwest Finland. Economic Geology 74, 10351059.

Le Breton, N. \& Thompson, A.B. 1988. Fluid-absent (dehydration) melting of biotite in metapelites in the early stages of crustal anatexis. Contributions to Mineralogy and Petrology 99, 226-237.

Lindroos, A. \& Ehlers, C. 1994. Emplacement, deformation and geochemistry of bimodal volcanics in Vestlax, SW Finland. Geological Survey of Finland, Special Paper 18, 173-184.

Lindroos, A., Romer, R.L., Ehlers, C. \& Alviola, R. 1996. Late orogenic Svecofennian deformation in SW Finland constrained by pegmatite ages. Terra Nova 8, 567-574.

Mäkitie, H. 1993. P-T determinations of tonalite from Östersundom - Lower granulite facies mineral assemblages in Sipoo, southern Finland. Geological Survey of Finland, Special Paper 18, 19-24.

Mehnert, K.R. 1971. Migmatites and the Origin of Granitic Rocks. Amsterdam: Elsevier. 405 p.

Nironen, M. 1989a. Emplacement and structural setting of granitoids in the early Proterozoic Tampere and Savo Schist Belts, Finland - implications for contrasting crustal evolution. Geological Survey of Finland, Bulletin 346.83 p.

Nironen, M. 1989b. The Tampere Schist Belt: Structural style within an Early Proterozoic volcanic arc system in southern Finland. Precambrian Research 43, 23-40.

Nironen, M. 1997. The Svecofennian Orogen: a tectonic model. Precambrian Research 86, 21-44.

Nironen, M. 1999. Structural and magmatic evolution in the Loimaa area, southwestern Finland. Bulletin of the Geological Society of Finland 71, 57-71.

Nurmi, P.A. \& Haapala, I. 1986. The Proterozoic granitoids of Finland: Granite types, metallogeny and relation to crustal evolution. Bulletin of the Geological Society of Finland 58, 203-233.

Passchier, C.W. \& Trouw, R.A.J. 1996. Microtectonics. Berlin: Springer-Verlag. 289 p.

Patchett, J. \& Kouvo, O. 1986. Origin of continental crust of 1.9-1.7 Ga age: $\mathrm{Nd}$ isotopes and $\mathrm{U}-\mathrm{Pb}$ zircon ages in the Svecokarelian terrain of South Finland. Contributions to Mineralogy and Petrology 92, 1-12.

Patiño Douce, A.E. \& Johnston, A.D. 1991. Phase equilibria and melt productivity in the pelitic system: implications for the origin of peraluminous granitoids and aluminous granulites. Contributions to Mineralogy and Petrology 107, 202-218.

Patiño Douce, A.E. \& Beard, J.S. 1995. Dehydration-melting of biotite gneiss and quartz amphibolite from 3 to 15 kbar. Journal of Petrology 36, 707-738.

Peltonen, P., Kontinen, A. \& Huhma, H. 1996. Petrology 
and geochemistry of metabasalts from the $1.95 \mathrm{Ga}$ Jormua Ophiolite, northeastern Finland. Journal of Petrology 37, 1359-1383.

Pietikäinen, K.J. 1994. The geology of the Paleoproterozoic Pori shear zone, southwestern Finland, with special reference to the evolution of veined gneisses from tonalitic protoliths. Unpublished PhD. thesis, Michigan Technological University. 129 p.

Ploegsma, M. \& Westra, L. 1990. The Early Proterozoic Orijärvi triangle (southwest Finland): a key area on the tectonic evolution of the Svecofennides. Precambrian Research 47, 51-69.

Rämö, O.T. \& Nironen, M. 1996. Petrogenesis of a 1.87 Ga post-tectonic bimodal granite suite in the Central Finland Granitoid Complex: the end of an orogenic cycle. In: Kohonen, T. \& Lindberg, B. (eds.) The 22nd Nordic Geological Winter Meeting, 8-11 January 1996, Turku, Finland. Abstracts of oral and poster presentations, p. 181.

Ramsay, J.G. \& Huber, M.I. 1987. The Techniques of Modern Structural Geology. Volume 2: Folds and Fractures. London: Academic Press. Pp. 309-700.

Sandiford, M. \& Powell, R. 1991. Some remarks on hightemperature - low pressure metamorphism in convergent orogens. Journal of Metamorphic Geology 9, 333-340.

Schneiderman, J.L. \& Tracy, R.J. 1991. Petrology of orthoamphibole-cordierite gneisses from the Orijärvi area, southwest Finland. American Mineralogist 76, 942-955.

Schreurs, J. \& Westra. L. 1986. The thermotectonic evolution of a Proterozoic, low pressure, granulite dome, West Uusimaa, SW Finland. Contributions to Mineralogy and Petrology 93, 236-250.

Sederholm, J.J. 1934. On migmatites and associated preCambrian rocks of southwestern Finland. Part III, The Åland Islands. Bulletin de la Commission géologique de Finlande 107. 68 p.

Selonen, O., Ehlers, C. \& Lindroos, A. 1996. Structural features and emplacement of the late Svecofennian Perniö granite sheet in southern Finland. Bulletin of the Geological Society of Finland 68, 5-17.

Sjöström, H. \& Bergman, S. 1996. Deformation zones in Central Sweden -relation to Svecokarelian orogeny. In: Kohonen, T. \& Lindberg, B. (eds.) The 22nd Nordic Geological Winter Meeting. 8-11 January 1996, Turku, Finland. Abstracts of oral and poster presentations, p. 194.

Stel, H., Cloethingh, S. Heeremans, M. \& van der Beek, P. 1993. Anorogenic granites, magmatic underplating and the origin of intracratonic basins in a non-extensional setting. Tectonophysics 226, 285-299.

Stel, H., Veenhof, R., Huizenga, J.M., Timmerman, M. \& Hartsink, J.M.H. 1989. Infra-supra structure relations of the microcline-granite dome in the Somero area, Svecofennides, SW Finland. Bulletin of the Geological Society of Finland 61, 131-134.

Stephens, M.B. \& Wahlgren C.-H. 1996. Thermal and mechanical responses to bilateral collision in the Svecokarelian orogen. In: Kohonen, T. \& Lindberg, B. (eds.) The 22nd Nordic Geological Winter Meeting. 8-11 January
1996, Turku, Finland. Abstracts of oral and poster presentations, p. 203.

Suominen, V. 1991. The chronostratigraphy of southwestern Finland with special reference to Postjotnian and Subjotnian diabases. Geological Survey of Finland, Bulletin $356.100 \mathrm{p}$.

Vaasjoki, M. 1977. Rapakivi granites and other postorogenic rocks in Finland: their age and the lead isotopic composition of certain associated galena mineralizations. Geological Survey of Finland, Bulletin 294. 64 p.

Vaasjoki, M. 1994. Valijärven hapan vulkaniitti: minimi Hämeen liuskejakson iäksi. Summary: Radiometric age of a meta-andesite at Valijärvi, Häme schist zone, southern Finland. Geologi 46, 91-92.

Vaasjoki, M. 1995. Rengon Rouvinmäen kvartsimonzodioriitti: uusi posttektoninen granitoidi. Summary: The Rouvinmäki quartzmonzodiorite at Renko: a new posttectonic granitoid. Geologi 47, 79-81.

Vaasjoki, M. 1996. Seglingen rengasintruusion tarkennettu radiometrinen ikä. Summary: A more precise U-Pb zircon for the Seglinge ring complex, Alland Islands, SW Finland. Geologi 48, 75-77.

Väisänen, M., Hölttä, P., Rastas, J., Korja, A. \& Heikkinen, P. 1994. Deformation, metamorphism and the deep structure of the crust in the Turku area, southwestern Finland. Geological Survey of Finland, Guide 37, 3541.

Van Duin, J.A. 1992. The Turku granulite area, SW Finland: a fluid-absent Svecofennian granulite occurrence. $\mathrm{PhD}$ thesis, Vrije Universiteit, Amsterdam. 234 p.

Van Duin, J.A. \& Nieman, C.P. 1993. Pressure and temperature history of a low-pressure transitional granulite area, Turku, SW Finland. Geologie en Mijnbouw 71, 259-280.

Van Staal, C.R. \& Williams, P.F. 1983. Evolution of a Svecofennian mantled gneiss dome in SW Finland, with evidence for thrusting. Precambrian Research 21, 101128.

Veenhof, R.P. \& Stel, H. 1991. A cleavage triple point and its mesoscopic structures: the Mustio Sink (Svecofennides of SW Finland). Precambrian Research 50, 269282.

Vernon, R.H. 1989. Porphyroblast-matrix microstructural relationship: recent approaches and problems. In: Daly, J.S., Cliff, R.A. \& Yardley, B.W.D. (eds.) Evolution of Metamorphic Belts. Geological Society, Special Publication 43, 83-102.

Vernon, R.H. \& Collins, W.J. 1988. Igneous microstructures in migmatites. Geology 16, 1126-1129.

Vielzeuf, D. \& Holloway, J.R. 1988. Experimental determination of the fluid-absent melting relations in the pelitic system. Consequences for crustal differentiation. Contributions to Mineralogy and Petrology 98, 257-276.

Ward, P. 1987. Early Proterozoic deposition and deformation at the Karelian craton margin in southeastern Finland. Precambrian Research 35, 71-93.

Windley, B.F. 1995. The Evolving Continents. 3rd edition. Chichester: John Wiley \& Sons. 526 p. 
Appendix 1. Microprobe analyses of selected minerals in metapelitic rocks. If not specially mentioned, the analyses are core compositions of minerals.

\begin{tabular}{|c|c|c|c|c|c|c|c|c|c|c|}
\hline Sample & PSH-94-4.1 & PSH-94-4.1 & PSH-93-13.1 & PSH-93-13.1 & PSH-93-191.2 & PSH-93-191.2 & PSH-93-98.7 & PSH-93-98.7 & PSH-93-119.1 & PSH-93-119.1 \\
\hline \multicolumn{11}{|c|}{ Map coordinates: } \\
\hline x (northing) & 6695150 & & 6737450 & & 6734200 & & 6713020 & & 6713300 & \\
\hline y (easting) & 2426850 & & 1529300 & & 1569060 & & 1567600 & & 1553700 & \\
\hline Mineral & grt & grt & grt & grt & grt & grt & grt & grt & grt & grt \\
\hline & core & rim & core & rim & rim & core & core & rim & core & rim \\
\hline Location & Kemiö & & Uusikaup & unki & $\begin{array}{r}\text { north of } \\
\text { Mynämäki }\end{array}$ & & Masku & & Mynämäki & \\
\hline $\mathrm{SiO}_{2}$ & 36.83 & 36.73 & 36.58 & 36.56 & 36.79 & 36.96 & 37.56 & 36.84 & 37.34 & 37.47 \\
\hline $\mathrm{TiO}_{2}$ & 0.03 & 0.03 & 0.00 & 0.03 & 0.00 & 0.07 & 0.04 & 0.04 & 0.00 & 0.05 \\
\hline $\mathrm{Al}_{2} \mathrm{O}_{3}$ & 20.98 & 21.04 & 20.63 & 20.81 & 21.52 & 21.43 & 21.01 & 20.79 & 21.62 & 21.40 \\
\hline $\mathrm{FeO}$ & 35.52 & 35.82 & 32.46 & 31.30 & 36.01 & 35.44 & 33.60 & 34.70 & 32.37 & 33.73 \\
\hline $\mathrm{MnO}$ & 1.51 & 1.88 & 5.59 & 7.33 & 0.31 & 0.34 & 0.40 & 0.44 & 0.47 & 0.60 \\
\hline $\mathrm{MgO}$ & 3.12 & 2.77 & 3.30 & 2.80 & 4.16 & 4.65 & 4.72 & 4.07 & 6.33 & 5.59 \\
\hline $\mathrm{CaO}$ & 1.25 & 1.15 & 0.75 & 0.76 & 0.83 & 0.79 & 0.86 & 0.78 & 0.92 & 0.91 \\
\hline $\mathrm{Na}_{2} \mathrm{O}$ & 0.10 & 0.11 & 0.00 & 0.00 & 0.10 & 0.10 & 0.00 & 0.00 & 0.11 & 0.10 \\
\hline $\mathrm{K}_{2} \mathrm{O}$ & 0.01 & 0.00 & 0.03 & 0.00 & 0.02 & 0.01 & 0.00 & 0.00 & 0.00 & 0.00 \\
\hline $\mathrm{BaO}$ & 0.00 & 0.06 & 0.06 & 0.05 & 0.05 & 0.00 & 0.00 & 0.00 & 0.08 & 0.03 \\
\hline $\mathrm{Cl}$ & 0.00 & 0.00 & 0.00 & 0.01 & 0.01 & 0.00 & 0.00 & 0.00 & 0.00 & 0.00 \\
\hline $\mathrm{F}$ & 0.14 & 0.17 & 0.00 & 0.00 & 0.15 & 0.14 & 0.00 & 0.00 & 0.16 & 0.15 \\
\hline Total & 99.48 & 99.76 & 99.40 & 99.64 & 99.95 & 99.93 & 98.19 & 97.66 & 99.40 & 100.02 \\
\hline \multicolumn{11}{|c|}{ Cations/12 oxygens } \\
\hline $\mathrm{Si}$ & 2.9845 & 2.9778 & 2.9804 & 2.9775 & 2.9536 & 2.9578 & 3.0307 & 3.0117 & 2.9635 & 2.9733 \\
\hline $\mathrm{Ti}$ & 0.0018 & 0.0015 & 0.0000 & 0.0015 & 0.0000 & 0.0043 & 0.0024 & 0.0025 & 0.0000 & 0.0031 \\
\hline $\mathrm{Al}$ & 2.0034 & 2.0107 & 1.9810 & 1.9973 & 2.0366 & 2.0212 & 1.9980 & 2.0031 & 2.0228 & 2.0017 \\
\hline $\mathrm{Fe}$ & 2.4076 & 2.4285 & 2.2115 & 2.1317 & 2.4174 & 2.3723 & 2.2673 & 2.3723 & 2.1489 & 2.2388 \\
\hline $\mathrm{Mn}$ & 0.1036 & 0.1289 & 0.3861 & 0.5055 & 0.0211 & 0.0232 & 0.0273 & 0.0305 & 0.0317 & 0.0401 \\
\hline $\mathrm{Mg}$ & 0.3766 & 0.3349 & 0.4012 & 0.3398 & 0.4979 & 0.5546 & 0.5678 & 0.4960 & 0.7491 & 0.6618 \\
\hline $\mathrm{Ca}$ & 0.1084 & 0.1002 & 0.0656 & 0.0667 & 0.0711 & 0.0680 & 0.0743 & 0.0683 & 0.0782 & 0.0775 \\
\hline $\mathrm{Na}$ & 0.0163 & 0.0170 & 0.0000 & 0.0000 & 0.0157 & 0.0157 & 0.0000 & 0.0000 & 0.0174 & 0.0148 \\
\hline $\mathrm{K}$ & 0.0013 & 0.0000 & 0.0030 & 0.0000 & 0.0023 & 0.0007 & 0.0000 & 0.0000 & 0.0000 & 0.0000 \\
\hline $\mathrm{Ba}$ & 0.0000 & 0.0019 & 0.0018 & 0.0016 & 0.0016 & 0.0000 & 0.0000 & 0.0000 & 0.0023 & 0.0008 \\
\hline $\mathrm{Cl}$ & 0.0000 & 0.0000 & 0.0004 & 0.0012 & 0.0011 & 0.0000 & 0.0000 & 0.0000 & 0.0000 & 0.0000 \\
\hline $\mathrm{F}$ & 0.0346 & 0.0446 & 0.0000 & 0.0000 & 0.0386 & 0.0354 & 0.0000 & 0.0000 & 0.0399 & 0.0364 \\
\hline $\mathrm{Mg} /(\mathrm{Mg}+\mathrm{Fe})$ & 0.135 & 0.121 & 0.154 & 0.138 & 0.171 & 0.189 & 0.200 & 0.173 & 0.259 & 0.228 \\
\hline $\mathrm{X}_{\mathrm{Fe}}$ & 0.804 & 0.812 & 0.722 & 0.700 & 0.804 & 0.786 & 0.772 & 0.800 & 0.714 & 0.742 \\
\hline $\mathrm{X}_{\mathrm{Mn}}$ & 0.035 & 0.043 & 0.126 & 0.166 & 0.007 & 0.008 & 0.009 & 0.010 & 0.011 & 0.013 \\
\hline$X_{\mathrm{Mg}}$ & 0.126 & 0.112 & 0.131 & 0.112 & 0.166 & 0.184 & 0.193 & 0.167 & 0.249 & 0.219 \\
\hline $\mathrm{X}_{\mathrm{Ca}}$ & 0.036 & 0.033 & 0.021 & 0.022 & 0.024 & 0.023 & 0.025 & 0.023 & 0.026 & 0.026 \\
\hline
\end{tabular}


Appendix 1 (cont.)

\begin{tabular}{|c|c|c|c|c|c|c|c|c|c|c|c|}
\hline Sample & $\begin{array}{r}\text { PSH-92- } \\
511.2\end{array}$ & $\begin{array}{r}\text { PSH-92- } \\
511.2\end{array}$ & $\begin{array}{r}\text { PSH-92- } \\
504.2\end{array}$ & $\begin{array}{r}\text { PSH-92- } \\
504.2\end{array}$ & PSH-94-3.2 & PSH-94-3.2 & PSH-93-10 & PSH-93-10 & $\begin{array}{r}\text { PSH-93- } \\
27.1 \mathrm{~B}\end{array}$ & $\begin{array}{r}\text { PSH-93- } \\
27.1 \mathrm{~B}\end{array}$ & $\begin{array}{r}\text { PSH-93- } \\
27.1 \mathrm{D}\end{array}$ \\
\hline \multicolumn{12}{|c|}{ Map coordinates: } \\
\hline x (northing) & 6727200 & & 6733000 & & 6703500 & & 6737750 & & 6737400 & & 6737400 \\
\hline y (easting) & 1555350 & & 1558950 & & 2423750 & & 1534000 & & 1532200 & & 1532200 \\
\hline Mineral & grt & grt & grt & grt & grt & grt & grt & grt & grt & grt & grt \\
\hline & core & rim & core & rim & rim & core & core & rim & core & rim & rim \\
\hline Location & Mynämäki & & $\begin{array}{l}\text { Mynämäki, } \\
\text { D3 shear zone }\end{array}$ & & Parainen & & Vellua & & Vellua & & \\
\hline $\mathrm{SiO}_{2}$ & 37.75 & 36.90 & 37.05 & 36.55 & 38.14 & 37.97 & 37.56 & 37.38 & 37.28 & 37.12 & 36.72 \\
\hline $\mathrm{TiO}_{2}$ & 0.01 & 0.01 & 0.09 & 0.05 & 0.04 & 0.01 & 0.04 & 0.03 & 0.08 & 0.03 & 0.02 \\
\hline $\mathrm{Al}_{2} \mathrm{O}_{3}$ & 21.30 & 21.01 & 20.77 & 21.14 & 21.49 & 21.73 & 21.06 & 20.87 & 22.95 & 20.71 & 20.61 \\
\hline $\mathrm{FeO}$ & 34.14 & 36.34 & 35.70 & 36.14 & 31.80 & 31.67 & 36.96 & 37.70 & 33.51 & 36.13 & 36.50 \\
\hline $\mathrm{MnO}$ & 0.75 & 1.00 & 0.86 & 1.03 & 0.92 & 0.78 & 1.22 & 1.85 & 1.82 & 2.06 & 2.33 \\
\hline $\mathrm{MgO}$ & 6.18 & 3.65 & 3.57 & 3.26 & 6.81 & 6.98 & 3.41 & 2.46 & 3.69 & 3.02 & 2.39 \\
\hline $\mathrm{CaO}$ & 0.91 & 0.86 & 0.99 & 0.93 & 0.88 & 0.92 & 0.97 & 1.01 & 0.86 & 0.84 & 0.87 \\
\hline $\mathrm{Na}_{2} \mathrm{O}$ & 0.00 & 0.00 & 0.10 & 0.11 & 0.13 & 0.12 & 0.00 & 0.00 & 0.00 & 0.00 & 0.00 \\
\hline $\mathrm{K}_{2} \mathrm{O}$ & 0.00 & 0.00 & 0.01 & 0.00 & 0.03 & 0.00 & 0.00 & 0.00 & 0.00 & 0.00 & 0.00 \\
\hline $\mathrm{BaO}$ & 0.00 & 0.00 & 0.08 & 0.01 & 0.09 & 0.00 & 0.00 & 0.00 & 0.00 & 0.00 & 0.00 \\
\hline $\mathrm{Cl}$ & 0.00 & 0.00 & 0.01 & 0.00 & 0.01 & 0.01 & 0.00 & 0.00 & 0.00 & 0.00 & 0.00 \\
\hline $\mathrm{F}$ & n.d. & n.d. & 0.16 & 0.13 & 0.17 & 0.16 & n.d. & n.d. & n.d. & n.d. & n.d. \\
\hline Total & 101.02 & 99.77 & 99.38 & 99.36 & 100.50 & 100.34 & 101.22 & 101.30 & 100.19 & 99.91 & 99.44 \\
\hline \multicolumn{12}{|c|}{ Cations/12 oxygens } \\
\hline $\mathrm{Si}$ & 2.9699 & 2.9807 & 2.9979 & 2.9674 & 2.9867 & 2.9730 & 2.9953 & 2.9995 & 2.9579 & 3.0045 & 2.9996 \\
\hline $\mathrm{Ti}$ & 0.0007 & 0.0004 & 0.0055 & 0.0032 & 0.0022 & 0.0008 & 0.0024 & 0.0018 & 0.0048 & 0.0018 & 0.0012 \\
\hline $\mathrm{Al}$ & 1.9747 & 2.0002 & 1.9806 & 2.0226 & 1.9834 & 2.0048 & 1.9794 & 1.9737 & 2.1461 & 1.9756 & 1.9842 \\
\hline $\mathrm{Fe}$ & 2.2465 & 2.4544 & 2.4154 & 2.4537 & 2.0827 & 2.0733 & 2.4649 & 2.5299 & 2.2235 & 2.4456 & 2.4935 \\
\hline $\mathrm{Mn}$ & 0.0497 & 0.0685 & 0.0589 & 0.0707 & 0.0608 & 0.0514 & 0.0824 & 0.1257 & 0.1223 & 0.1412 & 0.1612 \\
\hline $\mathrm{Mg}$ & 0.7243 & 0.4400 & 0.4303 & 0.3943 & 0.7947 & 0.8143 & 0.4054 & 0.2943 & 0.4365 & 0.3644 & 0.2911 \\
\hline $\mathrm{Ca}$ & 0.0763 & 0.0746 & 0.0854 & 0.0805 & 0.0742 & 0.0768 & 0.0829 & 0.0868 & 0.0731 & 0.0728 & 0.0761 \\
\hline $\mathrm{Na}$ & 0.0000 & 0.0000 & 0.0160 & 0.0170 & 0.0190 & 0.0178 & 0.0000 & 0.0000 & 0.0000 & 0.0000 & 0.0000 \\
\hline K & 0.0000 & 0.0000 & 0.0011 & 0.0000 & 0.0027 & 0.0000 & 0.0000 & 0.0000 & 0.0000 & 0.0000 & 0.0000 \\
\hline $\mathrm{Ba}$ & 0.0000 & 0.0000 & 0.0024 & 0.0004 & 0.0029 & 0.0000 & 0.0000 & 0.0000 & 0.0000 & 0.0000 & 0.0000 \\
\hline $\mathrm{Cl}$ & 0.0000 & 0.0000 & 0.0016 & 0.0000 & 0.0011 & 0.0007 & 0.0000 & 0.0000 & 0.0000 & 0.0000 & 0.0000 \\
\hline $\mathrm{F}$ & n.d. & n.d. & 0.0409 & 0.0339 & 0.0409 & 0.0406 & n.d. & n.d. & n.d. & n.d. & n.d. \\
\hline $\mathrm{Mg} /(\mathrm{Mg}+\mathrm{Fe})$ & 0.244 & 0.152 & 0.151 & 0.138 & 0.276 & 0.282 & 0.141 & 0.104 & 0.164 & 0.130 & 0.105 \\
\hline $\mathrm{X}_{\mathrm{Fe}}$ & 0.725 & 0.808 & 0.808 & 0.818 & 0.691 & 0.687 & 0.812 & 0.833 & 0.779 & 0.809 & 0.825 \\
\hline $\mathrm{X}_{\mathrm{Mn}}$ & 0.016 & 0.023 & 0.020 & 0.024 & 0.020 & 0.017 & 0.027 & 0.041 & 0.043 & 0.047 & 0.053 \\
\hline $\mathrm{X}_{\mathrm{Mg}}$ & 0.234 & 0.145 & 0.144 & 0.131 & 0.264 & 0.270 & 0.134 & 0.097 & 0.153 & 0.120 & 0.096 \\
\hline $\mathrm{X}_{\mathrm{Ca}}$ & 0.025 & 0.025 & 0.033 & 0.027 & 0.025 & 0.025 & 0.027 & 0.029 & 0.026 & 0.024 & 0.025 \\
\hline
\end{tabular}


Appendix 1 (cont.)

\begin{tabular}{|c|c|c|c|c|c|c|c|c|c|c|}
\hline $\begin{array}{l}\text { Sample } \\
\text { Mineral }\end{array}$ & $\begin{array}{r}\text { PSH-93-191.2 } \\
\text { crd } \\
\text { core }\end{array}$ & $\begin{array}{r}\text { PSH-93-191.2 } \\
\text { crd } \\
\text { rim }\end{array}$ & $\begin{array}{r}\text { PSH-93-98.7 } \\
\text { crd }\end{array}$ & $\begin{array}{r}\text { PSH-93-119.1 } \\
\text { crd }\end{array}$ & $\begin{array}{r}\text { PSH-92-511.2 } \\
\text { crd } \\
\text { corona on grt }\end{array}$ & $\begin{array}{r}\text { PSH-92-511.2 } \\
\text { crd }\end{array}$ & $\begin{array}{r}\text { PSH- } 92-504.2 \\
\text { crd }\end{array}$ & $\begin{array}{r}\text { PSH-94-3.2 } \\
\text { crd }\end{array}$ & $\begin{array}{r}\text { PSH-93-10 } \\
\text { crd }\end{array}$ & $\begin{array}{r}\text { PSH-93-27.1B } \\
\text { crd }\end{array}$ \\
\hline $\mathrm{SiO}_{2}$ & 47.81 & 47.80 & 46.69 & 48.46 & 48.06 & 47.81 & 48.34 & 48.20 & 47.35 & 47.26 \\
\hline $\mathrm{TiO}_{2}$ & 0.00 & 0.00 & 0.00 & 0.05 & 0.01 & 0.00 & 0.04 & 0.00 & 0.00 & 0.00 \\
\hline $\mathrm{Al}_{2} \mathrm{O}_{3}$ & 32.69 & 32.77 & 32.46 & 32.96 & 32.80 & 32.77 & 32.90 & 33.07 & 32.54 & 32.67 \\
\hline $\mathrm{FeO}$ & 9.67 & 9.21 & 8.97 & 8.32 & 8.79 & 9.29 & 7.68 & 7.81 & 11.82 & 12.02 \\
\hline $\mathrm{MnO}$ & 0.07 & 0.05 & 0.00 & 0.07 & 0.07 & 0.07 & 0.06 & 0.08 & 0.22 & 0.24 \\
\hline $\mathrm{MgO}$ & 7.07 & 7.62 & 7.66 & 8.30 & 8.09 & 7.98 & 8.42 & 8.63 & 6.05 & 5.62 \\
\hline $\mathrm{CaO}$ & 0.02 & 0.00 & 0.00 & 0.01 & 0.02 & 0.00 & 0.01 & 0.03 & 0.03 & 0.00 \\
\hline $\mathrm{Na}_{2} \mathrm{O}$ & 0.18 & 0.22 & 0.05 & 0.13 & 0.08 & 0.07 & 0.15 & 0.17 & 0.08 & 0.41 \\
\hline $\mathrm{K}_{2} \mathrm{O}$ & 0.01 & 0.01 & 0.00 & 0.00 & 0.00 & 0.00 & 0.01 & 0.02 & 0.00 & 0.00 \\
\hline $\mathrm{BaO}$ & 0.00 & 0.03 & 0.06 & 0.05 & 0.00 & 0.08 & 0.01 & 0.03 & 0.00 & 0.03 \\
\hline $\mathrm{Cl}$ & 0.01 & 0.00 & 0.00 & 0.02 & 0.02 & 0.01 & 0.00 & 0.01 & 0.00 & 0.01 \\
\hline F & 0.07 & 0.05 & 0.00 & 0.04 & 0.00 & 0.00 & 0.06 & 0.07 & 0.00 & 0.24 \\
\hline Total & 97.60 & 97.75 & 95.89 & 98.42 & 97.93 & 98.06 & 97.70 & 98.13 & 98.09 & 98.50 \\
\hline \multicolumn{11}{|c|}{ Cations/18 oxygens } \\
\hline $\mathrm{Si}$ & 4.9912 & 4.9749 & 4.9507 & 4.9876 & 4.9801 & 4.9634 & 4.9952 & 4.9671 & 4.9718 & 4.9543 \\
\hline $\mathrm{Ti}$ & 0.0000 & 0.0000 & 0.0000 & 0.0039 & 0.0008 & 0.0000 & 0.0031 & 0.0000 & 0.0000 & 0.0000 \\
\hline $\mathrm{Al}$ & 4.0221 & 4.0197 & 4.0565 & 3.9980 & 4.0057 & 4.0095 & 4.0068 & 4.0165 & 4.0269 & 4.0364 \\
\hline $\mathrm{Fe}$ & 0.8443 & 0.8016 & 0.7954 & 0.7161 & 0.7617 & 0.8066 & 0.6637 & 0.6731 & 1.0379 & 1.0538 \\
\hline $\mathrm{Mn}$ & 0.0062 & 0.0044 & 0.0000 & 0.0061 & 0.0061 & 0.0062 & 0.0053 & 0.0070 & 0.0196 & 0.0213 \\
\hline $\mathrm{Mg}$ & 1.1003 & 1.1823 & 1.2108 & 1.2735 & 1.2497 & 1.2350 & 1.2971 & 1.3258 & 0.9470 & 0.8783 \\
\hline $\mathrm{Ca}$ & 0.0022 & 0.0000 & 0.0000 & 0.0011 & 0.0022 & 0.0000 & 0.0011 & 0.0033 & 0.0034 & 0.0000 \\
\hline $\mathrm{Na}$ & 0.0364 & 0.0444 & 0.0103 & 0.0259 & 0.0161 & 0.0141 & 0.0301 & 0.0340 & 0.0163 & 0.0833 \\
\hline $\mathrm{K}$ & 0.0013 & 0.0013 & 0.0000 & 0.0000 & 0.0000 & 0.0000 & 0.0013 & 0.0026 & 0.0000 & 0.0000 \\
\hline $\mathrm{Ba}$ & 0.0000 & 0.0012 & 0.0025 & 0.0020 & 0.0000 & 0.0033 & 0.0004 & 0.0012 & 0.0000 & 0.0012 \\
\hline $\mathrm{Cl}$ & 0.0018 & 0.0000 & 0.0000 & 0.0035 & 0.0035 & 0.0018 & 0.0000 & 0.0017 & 0.0000 & 0.0018 \\
\hline $\mathrm{F}$ & 0.0231 & 0.0165 & 0.0000 & 0.0130 & 0.0000 & 0.0000 & 0.0196 & 0.0228 & 0.0000 & 0.0796 \\
\hline $\mathrm{Mg} /(\mathrm{Mg}+\mathrm{Fe})$ & 0.566 & 0.596 & 0.604 & 0.640 & 0.621 & 0.605 & 0.662 & 0.663 & 0.477 & 0.455 \\
\hline
\end{tabular}


Appendix 1 (cont.)

\begin{tabular}{|c|c|c|c|c|c|c|c|c|c|c|c|}
\hline Sample & $\begin{array}{r}\text { PSH-93- } \\
27.1 \mathrm{C}\end{array}$ & $\begin{array}{r}\text { PSH-93- } \\
27.1 \mathrm{D}\end{array}$ & PSH-94-4.1 & $\begin{array}{r}\text { PSH-93- } \\
13.1\end{array}$ & $\begin{array}{r}\text { PSH-93- } \\
191.2\end{array}$ & PSH-93-98.7 & PSH-93-98.7 & PSH-93-98.7 & $\begin{array}{r}\text { PSH-93- } \\
119.1\end{array}$ & $\begin{array}{r}\text { PSH-92- } \\
511.2\end{array}$ & $\begin{array}{r}\text { PSH-92- } \\
504.2\end{array}$ \\
\hline \multirow[t]{2}{*}{ Mineral } & crd & crd & bt & bt & bt & bt & bt & bt & bt & bt & bt \\
\hline & \multicolumn{3}{|c|}{ corona on grt } & \multicolumn{4}{|c|}{ incl. in grt } & \multicolumn{4}{|l|}{ incl. in kfs } \\
\hline $\mathrm{SiO}_{2}$ & 47.39 & 47.54 & 33.70 & 34.67 & 34.45 & 34.95 & 35.07 & 34.21 & 35.48 & 35.09 & 35.03 \\
\hline $\mathrm{TiO}_{2}$ & 0.02 & 0.00 & 1.75 & 1.98 & 2.52 & 2.70 & 4.33 & 2.84 & 4.15 & 3.69 & 2.87 \\
\hline $\mathrm{Al}_{2} \mathrm{O}_{3}$ & 32.58 & 32.72 & 17.57 & 19.62 & 18.66 & 17.47 & 17.83 & 19.04 & 16.34 & 17.63 & 17.61 \\
\hline $\mathrm{FeO}$ & 10.02 & 10.81 & 22.89 & 19.74 & 19.65 & 13.51 & 18.78 & 22.38 & 16.76 & 19.33 & 18.66 \\
\hline $\mathrm{MnO}$ & 0.21 & 0.37 & 0.03 & 0.15 & 0.03 & 0.00 & 0.01 & 0.06 & 0.02 & 0.03 & 0.09 \\
\hline $\mathrm{MgO}$ & 6.84 & 5.92 & 8.69 & 8.55 & 8.96 & 13.04 & 9.20 & 7.38 & 11.35 & 9.61 & 10.01 \\
\hline $\mathrm{CaO}$ & 0.02 & 0.02 & 0.07 & 0.04 & 0.00 & 0.02 & 0.01 & 0.00 & 0.00 & 0.02 & 0.00 \\
\hline $\mathrm{Na}_{2} \mathrm{O}$ & 0.39 & 0.19 & 0.24 & 0.14 & 0.23 & 0.25 & 0.08 & 0.15 & 0.13 & 0.13 & 0.18 \\
\hline $\mathrm{K}_{2} \mathrm{O}$ & 0.00 & 0.01 & 8.33 & 9.14 & 9.17 & 8.53 & 9.29 & 8.65 & 9.68 & 9.52 & 9.17 \\
\hline $\mathrm{BaO}$ & 0.06 & 0.05 & 0.07 & 0.07 & 0.17 & 0.10 & 0.09 & 0.17 & 0.13 & 0.12 & 0.24 \\
\hline $\mathrm{Cl}$ & 0.01 & 0.01 & 0.16 & 0.01 & 0.01 & 0.01 & 0.01 & 0.00 & 0.03 & 0.04 & 0.00 \\
\hline $\mathrm{F}$ & 0.16 & 0.00 & 0.70 & 0.16 & 0.47 & 0.97 & 0.70 & 0.40 & 0.92 & 0.51 & 0.40 \\
\hline Total & 97.70 & 97.64 & 94.19 & 94.25 & 94.31 & 91.55 & 95.40 & 95.28 & 94.98 & 95.71 & 94.25 \\
\hline \multicolumn{3}{|c|}{ Cations/18 oxygens } & \multicolumn{2}{|c|}{ Cations/22 oxygens } & & & & & & & \\
\hline $\mathrm{Si}$ & 4.9639 & 4.9942 & 5.2918 & 5.3464 & 5.3231 & 5.3818 & 5.3295 & 5.2822 & 5.3880 & 5.3422 & 5.3949 \\
\hline $\mathrm{Ti}$ & 0.0016 & 0.0000 & 0.2064 & 0.2290 & 0.2925 & 0.3127 & 0.4948 & 0.3298 & 0.4736 & 0.4224 & 0.3321 \\
\hline $\mathrm{Al}$ & 4.0220 & 4.0511 & 3.2518 & 3.5661 & 3.3986 & 3.1705 & 3.1934 & 3.4648 & 2.9243 & 3.1623 & 3.1967 \\
\hline $\mathrm{Fe}$ & 0.8777 & 0.9497 & 3.0063 & 2.5450 & 2.5395 & 1.7398 & 2.3867 & 2.8899 & 2.1285 & 2.4609 & 2.4034 \\
\hline $\mathrm{Mn}$ & 0.0186 & 0.0329 & 0.0041 & 0.0191 & 0.0035 & 0.0000 & 0.0013 & 0.0078 & 0.0023 & 0.0044 & 0.0113 \\
\hline $\mathrm{Mg}$ & 1.0681 & 0.9271 & 2.0351 & 1.9657 & 2.0640 & 2.9934 & 2.0843 & 1.6987 & 2.5703 & 2.1817 & 2.2971 \\
\hline $\mathrm{Ca}$ & 0.0022 & 0.0023 & 0.0113 & 0.0064 & 0.0002 & 0.0033 & 0.0016 & 0.0000 & 0.0000 & 0.0024 & 0.0000 \\
\hline $\mathrm{Na}$ & 0.0792 & 0.0387 & 0.0716 & 0.0404 & 0.0695 & 0.0747 & 0.0236 & 0.0449 & 0.0392 & 0.0378 & 0.0535 \\
\hline $\mathrm{K}$ & 0.0000 & 0.0013 & 1.6684 & 1.7977 & 1.8069 & 1.6757 & 1.8011 & 1.7039 & 1.8754 & 1.8484 & 1.8023 \\
\hline $\mathrm{Ba}$ & 0.0025 & 0.0021 & 0.0043 & 0.0040 & 0.0103 & 0.0060 & 0.0054 & 0.0103 & 0.0077 & 0.0073 & 0.0143 \\
\hline $\mathrm{Cl}$ & 0.0018 & 0.0018 & 0.0418 & 0.0024 & 0.0013 & 0.0026 & 0.0026 & 0.0000 & 0.0080 & 0.0095 & 0.0000 \\
\hline $\mathrm{F}$ & 0.0530 & 0.0000 & 0.3477 & 0.0790 & 0.2292 & 0.4724 & 0.3364 & 0.1953 & 0.4404 & 0.2451 & 0.1939 \\
\hline $\mathrm{Mg} /(\mathrm{Mg}+\mathrm{Fe})$ & 0.549 & 0.494 & 0.404 & 0.436 & 0.448 & 0.632 & 0.466 & 0.370 & 0.547 & 0.470 & 0.489 \\
\hline
\end{tabular}


Appendix 1 (cont.)

\begin{tabular}{|c|c|c|c|c|c|c|c|c|c|c|}
\hline $\begin{array}{l}\text { Sample } \\
\text { Mineral }\end{array}$ & $\begin{array}{r}\text { PSH-92-504.2 } \\
\text { bt } \\
\text { incl. in grt }\end{array}$ & $\begin{array}{r}\text { PSH-94-3.2 } \\
\text { bt }\end{array}$ & $\begin{array}{r}\text { PSH-93-10 } \\
\text { bt }\end{array}$ & $\begin{array}{r}\text { PSH-93-27.1A } \\
\text { bt }\end{array}$ & $\begin{array}{r}\text { PSH-93-27.1B } \\
\text { bt } \\
\text { altered } \\
\text { from grt }\end{array}$ & $\begin{array}{r}\text { PSH-93-27.1D } \\
b t\end{array}$ & $\begin{array}{r}\text { PSH-93-191.2 } \\
\text { kfs }\end{array}$ & $\begin{array}{r}\text { PSH-93-98.7 } \\
\mathrm{kfs}\end{array}$ & $\begin{array}{r}\text { PSH-92-511.2 } \\
\text { kfs }\end{array}$ & $\begin{array}{r}\text { PSH-93-27.1C } \\
\text { kfs }\end{array}$ \\
\hline $\mathrm{SiO}_{2}$ & 35.48 & 36.06 & 34.44 & 34.04 & 33.26 & 33.50 & 64.58 & 64.29 & 64.94 & 65.06 \\
\hline $\mathrm{TiO}_{2}$ & 1.33 & 3.71 & 2.89 & 3.10 & 0.06 & 1.69 & 0.00 & 0.04 & 0.00 & 0.00 \\
\hline $\mathrm{Al}_{2} \mathrm{O}_{3}$ & 17.96 & 17.16 & 17.86 & 18.63 & 20.93 & 21.02 & 18.93 & 18.63 & 18.72 & 18.82 \\
\hline $\mathrm{FeO}$ & 16.50 & 16.36 & 22.85 & 21.70 & 24.00 & 22.54 & 0.01 & 0.00 & 0.08 & 0.03 \\
\hline $\mathrm{MnO}$ & 0.01 & 0.00 & 0.05 & 0.09 & 0.04 & 0.10 & 0.01 & 0.00 & 0.09 & 0.03 \\
\hline $\mathrm{MgO}$ & 12.20 & 11.66 & 7.72 & 7.24 & 7.00 & 6.66 & 0.03 & 0.00 & 0.00 & 0.01 \\
\hline $\mathrm{CaO}$ & 0.00 & 0.03 & 0.00 & 0.01 & 0.03 & 0.04 & 0.09 & 0.03 & 0.02 & 0.00 \\
\hline $\mathrm{Na}_{2} \mathrm{O}$ & 0.18 & 0.14 & 0.13 & 0.17 & 0.17 & 0.18 & 1.58 & 0.97 & 1.56 & 0.89 \\
\hline $\mathrm{K}_{2} \mathrm{O}$ & 9.31 & 9.56 & 9.00 & 8.76 & 8.52 & 8.48 & 14.10 & 14.79 & 14.32 & 14.80 \\
\hline $\mathrm{BaO}$ & 0.12 & 0.08 & 0.09 & 0.16 & 0.14 & 0.02 & 0.28 & 0.33 & 0.30 & 0.53 \\
\hline $\mathrm{Cl}$ & 0.02 & 0.02 & 0.00 & 0.01 & 0.00 & 0.00 & 0.00 & 0.00 & 0.00 & 0.00 \\
\hline $\mathrm{F}$ & 0.54 & 0.58 & 0.53 & 0.65 & 0.74 & 0.12 & 0.02 & 0.00 & 0.00 & 0.00 \\
\hline Total & 93.64 & 95.37 & 95.56 & 94.56 & 94.89 & 94.35 & 99.62 & 99.08 & 100.03 & 100.16 \\
\hline \multicolumn{5}{|c|}{ Cations/22 oxygens } & \multicolumn{6}{|c|}{ Cations/8 oxygens } \\
\hline $\mathrm{Si}$ & 5.4305 & 5.4208 & 5.3282 & 5.2903 & 5.1892 & 5.2126 & 2.9788 & 2.9883 & 2.9875 & 2.9922 \\
\hline $\mathrm{Ti}$ & 0.1530 & 0.4189 & 0.3362 & 0.3623 & 0.0070 & 0.1977 & 0.0000 & 0.0014 & 0.0000 & 0.0000 \\
\hline $\mathrm{Al}$ & 3.2398 & 3.0406 & 3.2565 & 3.4124 & 3.8486 & 3.8547 & 1.0290 & 1.0206 & 1.0149 & 1.0198 \\
\hline $\mathrm{Fe}$ & 2.1124 & 2.0574 & 2.9564 & 2.8204 & 3.1315 & 2.9330 & 0.0002 & 0.0000 & 0.0031 & 0.0010 \\
\hline $\mathrm{Mn}$ & 0.0006 & 0.0000 & 0.0066 & 0.0118 & 0.0053 & 0.0132 & 0.0002 & 0.0000 & 0.0034 & 0.0012 \\
\hline $\mathrm{Mg}$ & 2.7845 & 2.6135 & 1.7805 & 1.6774 & 1.6281 & 1.5449 & 0.0023 & 0.0000 & 0.0000 & 0.0003 \\
\hline $\mathrm{Ca}$ & 0.0000 & 0.0055 & 0.0000 & 0.0017 & 0.0050 & 0.0067 & 0.0044 & 0.0015 & 0.0011 & 0.0001 \\
\hline $\mathrm{Na}$ & 0.0525 & 0.0420 & 0.0390 & 0.0512 & 0.0514 & 0.0543 & 0.1410 & 0.0874 & 0.1389 & 0.0792 \\
\hline $\mathrm{K}$ & 1.8188 & 1.8344 & 1.7763 & 1.7368 & 1.6958 & 1.6833 & 0.8299 & 0.8770 & 0.8405 & 0.8680 \\
\hline $\mathrm{Ba}$ & 0.0071 & 0.0049 & 0.0055 & 0.0097 & 0.0086 & 0.0012 & 0.0050 & 0.0060 & 0.0053 & 0.0096 \\
\hline $\mathrm{Cl}$ & 0.0049 & 0.0059 & 0.0000 & 0.0026 & 0.0000 & 0.0000 & 0.0000 & 0.0000 & 0.0000 & 0.0002 \\
\hline $\mathrm{F}$ & 0.2614 & 0.2748 & 0.2593 & 0.3195 & 0.3651 & 0.0591 & 0.0026 & 0.0000 & 0.0000 & 0.0000 \\
\hline $\mathrm{Mg} /(\mathrm{Mg}+\mathrm{Fe})$ & 0.569 & 0.560 & 0.376 & 0.373 & 0.342 & 0.345 & & & & \\
\hline $\mathrm{X}_{\mathrm{Ca}}$ & & & & & & & 0.005 & 0.002 & 0.001 & 0.000 \\
\hline $\mathrm{X}_{\mathrm{Na}}$ & & & & & & & 0.145 & 0.091 & 0.142 & 0.084 \\
\hline $\mathrm{X}_{\mathrm{K}}$ & & & & & & & 0.851 & 0.908 & 0.857 & 0.916 \\
\hline
\end{tabular}


Appendix 1 (cont.)

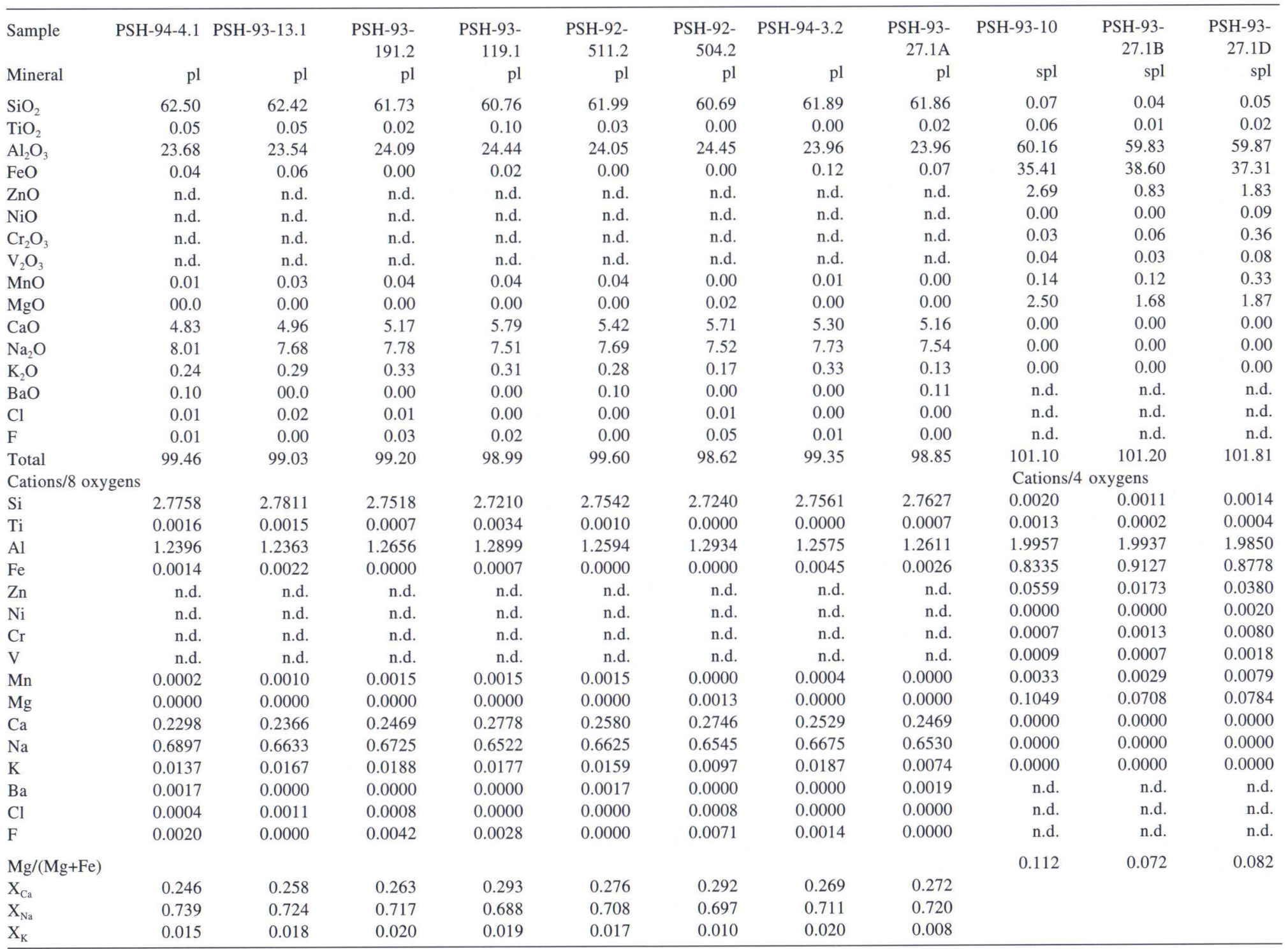


Appendix 2. Temperatures, pressures and water activities calculated with the GEOPATH and THERMOCALC $\left(T_{\text {avg }}, P_{\text {avg }}\right)$ softwares. If not mentioned, the analysed points used in calculations represent cores of big grains in mesosomes. $*=$ estimated $a_{H 2 O}, * *=$ data from Hölttä (1986). For the THERMOCALC the assemblage almprp-grs-phl-ann-east-sil-kfs-an-qtz was used in all calculations (for specimen PSH-93-27.1 also spl-hc) except PSH-92-504.2 which was calculated without $k f s$ which is not present in the mineral assemblage. $s d=$ standard deviation given by the THERMOCALC.

\begin{tabular}{|c|c|c|c|c|c|c|c|c|}
\hline Sample & Reaction & $T_{\text {grt-bt }}$ & $\mathrm{T}_{\text {grt-crd }}$ & $\mathrm{T}_{\text {avg }}(\mathrm{sd})$ & $P_{\text {grt-crd }}$ & $\mathrm{P}_{\mathrm{avg}}(\mathrm{sd})$ & $\mathrm{a}_{\mathrm{H} 2 \mathrm{O}}$ & \\
\hline \multicolumn{9}{|l|}{ Vellua } \\
\hline PSH-93-10 & & 707 & 731 & & 4.9 & & 0.85 & \\
\hline PSH-93-28.2 & & 681 & 679 & $649(43)$ & 4.1 & $3.7(0.5)$ & & \\
\hline PSH-93-28.2 & $\begin{array}{l}\text { grt rim }+ \text { adj. } \\
\text { crd after grt }\end{array}$ & & 578 & $621(39)$ & 2.6 & $3.4(0.4)$ & & \\
\hline PSH-93-27.1 & & 697 & 698 & $586(48)$ & 4.3 & $3.5(0.6)$ & 0.48 & \\
\hline PSH-93-27.1 & $\begin{array}{l}\text { grt rim + adj. } \\
\text { bt+crd+spl after grt }\end{array}$ & 625 & 621 & $549(46)$ & 3.1 & $2.8(0.5)$ & 0.61 & \\
\hline PSH-93-52.4 & & 670 & 662 & & 3.7 & & 0.553 & \\
\hline PSH-93-52.4 & $\begin{array}{l}\text { grt rim }+ \text { crd } \\
\text { after grt }\end{array}$ & & 643 & & 3.3 & & $0.40 *$ & \\
\hline PSH-93-13.1 & & 626 & & & & & & \\
\hline \multicolumn{9}{|c|}{ Region between Vellua and Mynämäki granulites } \\
\hline PSH-93-140 & & 740 & 761 & & 5.4 & & 0.47 & \\
\hline PSH-93-191.2 & & 715 & 769 & & 5.6 & & 0.63 & \\
\hline PSH-93-191.2 & $\begin{array}{l}\text { grt rim+crd } \\
\text { after grt }\end{array}$ & & 605 & & 3.1 & & $0.40^{*}$ & \\
\hline PSH-93-166.3 & & 706 & 769 & & 5.6 & & 0.73 & \\
\hline PSH-92-504.2 & $\begin{array}{l}\text { grt rim }+ \text { crd }+ \\
\text { bt in matrix }\end{array}$ & 567 & 538 & $513(85)$ & 2.4 & $3.5(0.7)$ & & D3 shear \\
\hline \multicolumn{9}{|c|}{ Mynämäki granulites } \\
\hline PSH-92-511.2 & & 758 & 824 & $704(62)$ & 6.5 & $4.6(0.7)$ & 0.53 & \\
\hline PSH-92-511.2 & $\begin{array}{l}\text { grt rim }+ \text { adj. } \\
\text { crd after grt }\end{array}$ & & 601 & $671(43)$ & 3.2 & $4.3(0.5)$ & 0.35 & \\
\hline PSH-93-119.1 & & 715 & 815 & & 6.6 & & 0.57 & \\
\hline PSH-94-12.1 & & 769 & 801 & & 6.3 & & 0.40 & $\begin{array}{l}\text { D3 high-grade } \\
\text { shear }\end{array}$ \\
\hline PSH-94-12.2 & & 725 & 785 & & 6.2 & & 0.36 & Leucosome \\
\hline L-1-6 & & 740 & 770 & & 5.9 & & $0.33 * *$ & \\
\hline M-4-9 & & & 768 & & $5.9 * *$ & & & Leucosome \\
\hline M-5-9 & & & 733 & & $5.4^{* *}$ & & & \\
\hline \multicolumn{9}{|c|}{ Parainen granulites } \\
\hline PSH-94-3.2 & & 728 & 819 & & 6.7 & & 0.50 & \\
\hline PSH-93-212 & & 752 & 818 & & 6.7 & & 0.36 & \\
\hline PSH-94-29.2 & & 730 & 735 & $747(53)$ & 5.3 & $5.3(0.6)$ & 0.302 & \\
\hline PSH-94-29.2 & $\begin{array}{l}\text { grt rim }+ \text { crd } \\
\text { after grt }\end{array}$ & & 641 & $686(55)$ & 4.2 & $4.7(0.7)$ & $0.40^{*}$ & \\
\hline
\end{tabular}


Appendix 2 (cont.)

\begin{tabular}{|c|c|c|c|c|c|c|c|}
\hline Sample & Reaction & $T_{\text {grt-bt }}$ & $\mathrm{T}_{\text {grt-crd }} \quad \mathrm{T}_{\mathrm{avg}}(\mathrm{sd})$ & $\mathrm{P}_{\text {grt-crd }}$ & $P_{\text {avg }}(\mathrm{sd})$ & $\mathrm{a}_{\mathrm{H} 2 \mathrm{O}}$ & \\
\hline \multicolumn{8}{|c|}{ Region between the Mynämäki and Parainen granulites } \\
\hline PSH-93-98.4 & & 725 & 754 & & 5.3 & 0.42 & Leucosome \\
\hline PSH-93-98.7 & $\begin{array}{l}\text { grt core }+\mathrm{bt} \\
\text { inclusion in } \mathrm{kfs}\end{array}$ & 803 & & & & & \\
\hline PSH-93-98.7 & & 697 & 728 & 5.0 & & 0.39 & \\
\hline PSH-92-505.1 & & 667 & 674 & 4.2 & & 0.38 & \\
\hline PSH-92-505.5 & & 605 & 557 & 2.8 & & 0.21 & $\begin{array}{l}\text { Leucosome } \\
\text { D3 shear }\end{array}$ \\
\hline PSH-92-505.6 & & 621 & 598 & $\begin{array}{c}3.2 \\
\text { zone }\end{array}$ & & 0.32 & \\
\hline PSH-93-207 & & 716 & 744 & 5.2 & & 0.40 & \\
\hline PSH-93-215 & & 741 & 782 & 5.7 & & 0.46 & \\
\hline \multicolumn{8}{|c|}{ Region east of the Mynämäki and Parainen granulites } \\
\hline PSH-94-22.1 & & 640 & & & & & \\
\hline PSH-94-35.1 & & 705 & & & & & \\
\hline PSH-94-4.1 & & 657 & & & & & \\
\hline PSH-93-155.1 & & 641 & 645 & 3.7 & & 0.31 & \\
\hline PSH-94-44.1 & & 664 & 669 & 4.0 & & 0.51 & \\
\hline PSH-94-60 & & 661 & 662 & 3.9 & & 0.40 & \\
\hline PSH-94-65 & & 695 & 719 & 4.7 & & 0.49 & \\
\hline PSH-94-67 & & 731 & 714 & 4.5 & & 0.40 & \\
\hline PSH-94-27 & & 687 & 708 & 4.7 & & 0.36 & \\
\hline PSH-92-528.2 & & 656 & 666 & 3.7 & & $0.40 *$ & \\
\hline
\end{tabular}

